University of New Hampshire

University of New Hampshire Scholars' Repository

Doctoral Dissertations

Student Scholarship

Spring 2001

\title{
The specter of Salem in American culture
}

Gretchen A. Adams

University of New Hampshire, Durham

Follow this and additional works at: https://scholars.unh.edu/dissertation

\section{Recommended Citation}

Adams, Gretchen A., "The specter of Salem in American culture" (2001). Doctoral Dissertations. 4.

https://scholars.unh.edu/dissertation/4

This Dissertation is brought to you for free and open access by the Student Scholarship at University of New Hampshire Scholars' Repository. It has been accepted for inclusion in Doctoral Dissertations by an authorized administrator of University of New Hampshire Scholars' Repository. For more information, please contact Scholarly.Communication@unh.edu. 


\section{INFORMATION TO USERS}

This manuscript has been reproduced from the microfilm master. UMI films the text directly from the original or copy submitted. Thus, some thesis and dissertation copies are in typewriter face, while others may be from any type of computer printer.

The quality of this reproduction is dependent upon the quality of the copy submitted. Broken or indistinct print, colored or poor quality illustrations and photographs, print bleedthrough, substandard margins, and improper alignment can adversely affect reproduction.

In the unlikely event that the author did not send UMI a complete manuscript and there are missing pages, these will be noted. Also, if unauthorized copyright material had to be removed, a note will indicate the deletion.

Oversize materials (e.g., maps, drawings, charts) are reproduced by sectioning the original, beginning at the upper left-hand comer and continuing from left to right in equal sections with small overlaps. Each original is also photographed in one exposure and is included in reduced form at the back of the book.

Photographs included in the original manuscript have been reproduced xerographically in this copy. Higher quality $6^{\prime \prime} \times 9^{\prime \prime}$ black and white photographic prints are available for any photographs or illustrations appearing in this copy for an additional charge. Contact UMI directly to order.

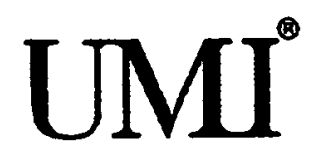

Bell \& Howell Information and Learning 300 North Zeeb Road, Ann Arbor, MI 48106-1346 USA 800-521-0600 
THE SPECTER OF SALEM IN AMERICAN CULTURE

BY

\begin{abstract}
GRETCHEN A. ADAMS
B.A. University of Oregon, 1994

M.A. University of Oregon, 1996
\end{abstract}

DISSERTATION

Submitted to the University of New Hampshire in Partial Fulfillment of the Requirements for the Degree of

Doctor of Philosophy

In

History

May, 2001 
UMI Number: 3006125

Copyright 2001 by

Adams, Gretchen A.

All rights reserved.

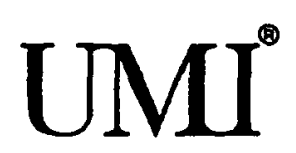

UMI Microform 3006125

Copyright 2001 by Bell \& Howell Information and Learning Company.

All rights reserved. This microform edition is protected against unauthorized copying under Titte 17, United States Code.

Bell \& Howell Information and Leaming Company

300 North Zeeb Road

P.O. Box 1346

Ann Arbor, Ml 48106-1346 


\section{ALL RIGHTS RESERVED}

c. 2001

GRETCHEN A. ADAMS 
This dissertation has been examined and approved.
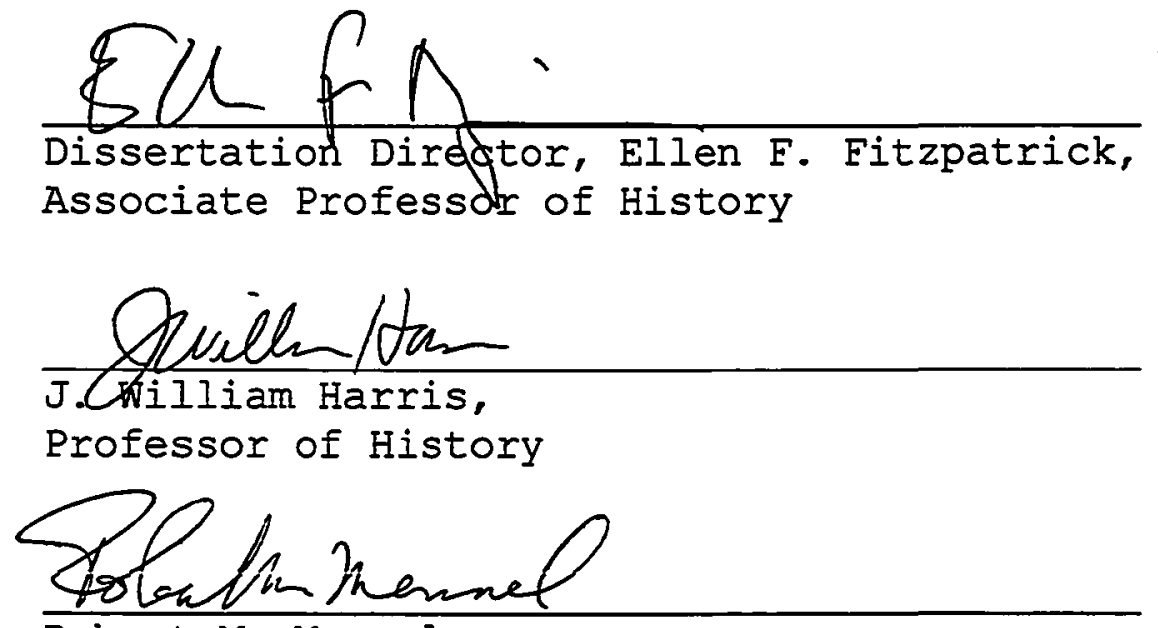

Robert M. Mennel, Professor of History

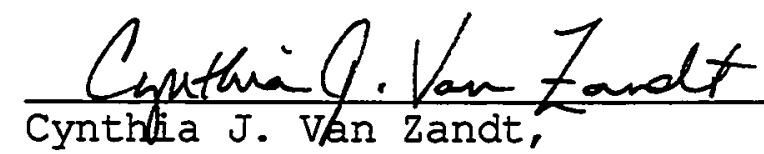

Assistant Professor of History

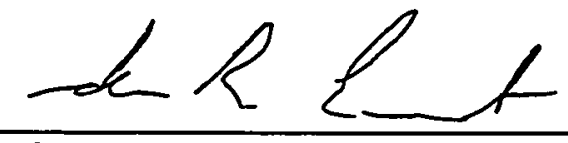

John R. Ernest,

Associate Professor of English

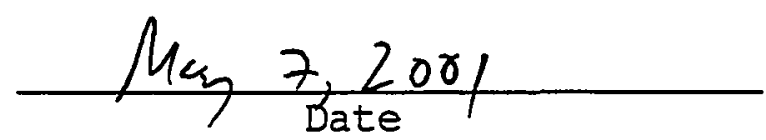


In Loving Memory of

Howard Palmer Oldfield

Failing to fetch me at first keep encouraged, Missing me one place search another,

I stop somewhere waiting for you.

Walt Whitman

Song of Myself 
ACKNOWLEDGMENTS

Because I am an unusually fortunate person, I have many people to thank. And, it is my privilege to do so here. Each of them has my sincere gratitude for all favors---large, small, academic, and personal. Since this project concerns, to a fair degree, "memory," I hope mine (and my notes) are as good as they should be. I have tried to remember every person who took the time to help.

It is customary, but in this case also a pleasure, to thank my dissertation director Ellen F. Fitzpatrick first. There is simply no finer advisor or mentor. Period. The members of my dissertation committee are, happily, exactly who I wanted and they have consistently gone above and beyond the call of duty whether it was the defense schedule or writing what must have seemed like a never-ending round of letters for one thing or another. Thank you: J. William Harris, Robert M. Mennel, Cynthia J. Van Zandt, and John R. Ernest.

For assistance that ranged from encouragement to comments to suggestions, citations, criticism, translations, and conversations about the project at venues that ranged from conferences, to research libraries, seminars, e-mail, and even kitchen tables, many thanks to: Evan Haefeli; Carol 
Karlsen; Jill Lepore; Jim Cullen; Holly Snyder; Kristin

Earmelant; Robert Allison; Janet Coryell; Roger W. Bowen; W. Jeffrey Bolster; Bernard Rosenthal; Marla Miller; Stephen Nissenbaum; Elizabeth Reis; Udo Hebel; Robert Mitchell; and, James Mohr.

For generous financial support that made the research and writing of this dissertation possible: Boston Athenaeum; American Historical Association; Friends of Longfellow House; University of Glasgow; Virginia Historical Society; Smith College Archives and the Sophia Smith Collection. Each not only provided essential financial support but extended access to terrific archival sources and genuine individual enthusiasm for the project. I've benefited many times from the generosity of the Graduate School of the University of New Hampshire and, this past year, again through a Dissertation Fellowship. I thank the school and especially Helen Cook and Dean Harry Richards --- I promise to stop requesting things, graduate, and go away now.

Two institutions deserve the special mention I am happy to give them because I Iived at both for extended periods during the final year or so of work. The John Nicholas Brown Center for the Study of American Civilization at Brown University provided the best possible working environment and incredible libraries during the winter and spring of 2000. It was a privilege to be in residence. Special thanks 
go to the people who make the JNBC such a special place: Director Joyce Bothelo, Denise Bastien, and Alex Dunwoodie. Also, to Richard Ring for his generous assistance with the collections of the John Carter Brown Library. And thank you to the entire staff of the John Hay and Rockefeller Libraries whose help enriched this project in countless ways.

The American Antiquarian Society gave me a month-long fellowship and then probably wondered if I would ever leave. Much of the research was done and most of the dissertation draft was written during extended stays from July 2000-May 2001 in rooms 4 and 5 of Goddard-Daniels House and in Antiquarian Hall. There is no finer place to research such a project and no finer group of people with whom to work. It is difficult to determine with this group where intellectual and professional thanks end and where the personal begin. So, I will not try. But I will express my sincerest gratitude for kindnesses both personal and professional to: Caroline Sloat; John B. Hench; Joanne Chaison; Marie Lamoreaux; Jim Moran; Bill Young; Caroline Stoffel; and, Alice Gardiner. I'd particularly like to thank the fellows in residence over most of that period who made living and working away from home for an extended period as easy as it could be and whose pool playing, encouragement, and advice during a long season of job hunting and writing will never 
be forgotten: Richard Fox; Cathy Corman; Alan Taylor; Vince DiGirolamo; and, Melissa J. Homestead. I'm sorry I'm so very bad at pool.

As good friends and fine historians themselves, Kate Clifford Larson, JoAnne Thomas and Kurt Graham have done heroic duty. They have provided intellectual companionship, field expertise, lodging, advice, piano playing, criticism, readings, e-mail, wine, and they know how to keep secrets. Most importantly, each is an unparalleled storyteller who tells hilarious tales---about people I sometimes didn't even know---to get me away from the desk once in a while. (If I live to be 100 I will never forget: "The doctor told them they were in love.") Your turn next year and I hope that I give each of you a fraction of what you have so generously given to me this year.

The support of another group of historian friends who did not endure the "on call" nature of friendship quite so intensely but nonetheless were always supportive, often funny, and always there: Shannon Erystak, Ellen Pearson, Mike Foley, David Chapin, and, Scott Hancock.

Mark and Drew don't read history but that doesn't matter at all. They always did the things that do matter. As did Louise Wheeler, Bruce Parker, and Iinda and Bob Arnold.

The man to whom this would have meant everything did not live to see it even begun. He gave me the gifts of a 
love of stories, an abiding appreciation for the words of Iincoln, Emerson, and Whitman and, most of all, a fascination with his New England. I miss him still and hope he somehow knew. As my grandfather was an unusually prescient man, I suspect he did. This unusual story is for him. 
DEDICATION ...........................

ACKNOWLEDGMENTS. .........................

ABSTRACT ...........................

$\begin{array}{ll}\text { CHAPTERS PAGE } & \text { PAT }\end{array}$

INTRODUCTION...........................

I. USEEUL KNOWIEDGE. ....................22

II. NOT TO HELI BUT TO SAIEM......................

III. PURITANS, WITCHES, AND SOUTHERN RHETORIC......... 220

IV. THE CULTURAI WORK OE SAIEM WITCHCRAET: FROM

PURITAN TO PILGRIM....................... 170

CONCLUSION..............................215

BIBLIOGRAPHY.......................... 232 


\section{ABSTRACT}

\section{THE SPECTER OF SALEM IN AMERICAN CULTURE}

\section{By}

Gretchen A. Adams

University of New Hampshire, May 2001

The specter of Salem witchcraft haunts the American imagination. No other historical event has provided such a wide range of scholars, dramatists, fiction writers, poets, and amateur sleuths with a subject that so stubbornly resists a final resolution. Although barely nine months passed from the first accusations of witchcraft to the last, those nine months of accusations, confessions, denials, trials, and executions have spawned a vast literature which for 300 years has sought to fix blame or find reason for the ordeal of the witch trials of 1692 . The Specter of Salem in American Culture examines this persistent interest by tracing the cultural memory of Salem witchcraft in the nineteenth century.

This thesis argues that by examining the use of Salem witchcraft as a metaphor, we can see the cultural work of history in nation building. By its invocation within a variety of public controversies that ranged from the 
religious innovations of the 1830 s, to the sectional crisis and Civil war of the 1850s and 1860s, and the era of national Reconstruction Salem served to demarcate cultural boundaries and define national identity. 


\section{INTRODUCTION}

The specter of Salem witchcraft haunts the American imagination. No other historical event has provided such a wide range of scholars, dramatists, fiction writers, poets, and amateur sleuths with a subject that so stubbornly resists a final resolution. Although barely nine months passed from the first accusations of witchcraft to the last, those nine months of accusations, confessions, denials, trials, and executions have spawned a vast literature which for 300 years has sought to fix blame or find reason for the ordeal of the witch trials of 1692 .

Historian and geographer David Lowenthal said of historical landscapes in the physical world that "features recalled with pride are apt to be safeguarded against erosion and vandalism; those that reflect shame may be ignored or expunged from the landscape."1 The same might be said for the American cultural landscape. The nation has preserved, guarded and celebrated that in which it has found reason to take pride and that which appears to realize its ideals. Historical events or individuals may, of course, serve as fitting cultural symbols at one time but not another. Others are deliberately, or mercifully, "forgotten," especially when they evoke the "shame" 
Lowenthal describes.

Salem witchcraft appears to defy all such categories. ${ }^{2}$ For although it belongs to a distant past, it has remained a vivid and persistent element of American national memory through rapidly changing times and across the centuries. And though it represents a moment of shame, it has hardly receded from view as a cultural symbol. On the contrary, in many ways, it remains as evocative today as it was two centuries ago. In short, Salem witchcraft has presented two mysteries. The first has been centered directly on the events of 1692: what happened in Salem -or, more accurately "why" did things happen as they did? Secondly, why have Americans preserved the memory of Salem and excavated it so persistently?

The "why" of the terrible events that took place in Salem in 1692 is not considered here. Readers looking for information on Salem witchcraft in the seventeenth century are referred to the huge historical literature devoted to that ever-fascinating, and elusive, episode in early American history. ${ }^{3}$ This study examines another compelling, and also puzzling question - namely, why Salem has been so persistent in American cultural memory. It does so by exploring the fortunes of Salem witchcraft in the nineteenth century - a time of tremendous social, economic, political 
and cultural change when Salem nonetheless occupied an enduring place in the national scene. Certainly the presence of Salem through the century would demonstrate its resilience and perhaps, point to the origins of our enduring fascination.

Most are familiar, at least in part, with the basic story of the Salem witchcraft trials: In early 1692, in the household of the minister Samuel Parris, two young girls (his nine-year-old daughter Betty and his eleven-year-old niece Abigail Williams) began having "fits" that resembled seizures. As one witness reported, the girls made claims of being "bitten and pinched by invisible agents; their limbs wracked and tormented so as might move an [sic] heart of stone, to sympathize with them."4 Mr. Parris, as was customary, consulted with physicians and other ministers to determine the nature of the girls' affliction. Their verdict: the children suffered from witchcraft. Neither prayer nor fasting, the relied-upon remedies in such cases, ended the siege. Soon, a search for a possible source of bewitchment was begun, and three local women were accused and arrested. Instead of ending the episode with a trial of the three, the investigation accelerated and a court of oyer and Terminer was appointed to look for what was now believed to be a widespread conspiracy of witches in the 
Massachusetts Bay colony. Before the court was suspended in October 1692, the destruction to the community was staggering. The toll in part: 200 accused, most of them arrested and imprisoned; nineteen hanged including a minister; one man pressed to death with stones; at least four persons dying while imprisoned; accusations reaching as far up the social ladder as the wives of a minister and governor; several prominent members of the community fleeing to New York to avoid arrest, at the very least. 6

These constituted a sensational set of facts with a ready potential for drama. But other factors in this case are tantalizing: the seemingly copious body of contemporary materials from trial transcripts to published commentary that record but do not satisfactorily explain the events of 1692; the disturbing knowledge that those who pled innocent died, while those who confessed their guilt lived; the fact that although traditional procedures were followed in the initial examination of the girls in the Parris household, traditional judicial procedures regarding evidence in such cases were not. Instead, controversial "spectral" evidence (or, the unsupported testimony of those claiming to be tormented by the invisible "shapes" of the accused) was allowed. And, finally, there is the mystery as to why a local (albeit capital) crime rarely pursued with any vigor 
exploded into a regional crisis of tragic proportions that left an indelible mark on American history.

The "story," then, of Salem witchcraft is one whose outlines are familiar, but it is also one which has defied explanation. Furthermore, it has been filtered through the accretion of narrative inventions and analytical conclusions over the intervening centuries. ${ }^{7}$ Some of the historical conclusions and interpretations of the 1692 trials have also become familiar. The tragedy has alternately been considered a result of religious fanaticism, power-mad ministers, hysterical girls, local disputes, misogyny, anxiety caused by political turmoil, frontier life, Indian wars, hallucinations caused by rotting grain, psychological distress, or even a result of the persecution of "real" witches.

This thesis considers a different element of the "mystery" -our enduring interest in Salem witchcraft over many centuries. Salem has had a long career as a plot device in American fiction. It has also served as a standard subject in histories of the United States. Most of all, it became an enduring metaphor that addressed a variety of concerns over the long course of American history. This aspect of the events of the late seventeenth century raises a series of questions that provide the focus of attention 
here: How did Salem witchcraft become a cultural metaphor? What meaning did Salem have for the many individuals who invoked it at different times and in different places over the nineteenth century? Did Salem always carry its presentday meaning of persecution? Or, was it used for different purposes prior to the modern period? Why the long national memory of an event that was, as we will see, set in what became America but, yet, in its Iong career, was somehow never truly considered of America? And, finally, why was Salem, as opposed to some other event in early American history, so peculiarly evocative to generation after generation of Americans of some essential truth about their history? These questions have been crucial to my inquiry. While a continuous thread links the metaphor of Salem to its present-day association with "persecution," this thesis considers an earlier moment in its long and evolving history. Early in the nineteenth century, Salem was invoked most often to express anxiety about "delusions" that threatened central American values of "reason" and "progress." Late in the nineteenth century, at a very different historical moment, "tolerance" was a principle concern. Yet across both periods, Salem witchcraft served, as we will see, as a cautionary tale about an imagined past that bound Americans to their collective history. The 
"imagined past" is crucial to understanding the metaphor of Salem witchcraft for it provided a reading of history that defined American beliefs and behaviors even as it marked cultural boundaries.

Indeed, by examining the use of Salem witchcraft as metaphor, we can see the cultural work of history in nationbuilding. Historians have devoted considerable attention in the past decade (and well before) to exploring the construction of an American identity. ${ }^{8}$ These studies have concentrated either upon the ways in which identity is defined against external "others" or created through patriotic symbols and public activities. My project, by contrast, considers how an historical event that preceded American independence was continually evoked and reconstructed to demarcate cultural boundaries and define national identity. Salem witchcraft as a metaphor has acted as just such a force and delimiter.

For various groups of Americans, from the 1830 s onward, have deployed Salem as an illustrative metaphor to oppose cultural trends they have judged as extreme and destructive. Among the phenomena that were so perceived over the course of the nineteenth century were Mormonism, Spiritualism, and abolitionism, among other movements. Salem was persistently invoked when the behavior or belief system in question moved 
beyond the merely eccentric and private into the public arena in ways that had the potential or so it seemed to undermine the values or the safety of the community. In moments of cultural crisis, various Americans consistently turned to Salem to define normative cultural behaviors and to condemn ideas and actions that fell outside of implicitly agreed upon parameters of what was appropriately "American." In drawing and maintaining these cultural boundaries, participants reinforced their own sense of what Benedict Anderson called the "imagined community."9

This project began with a consideration of how colonial symbols have formed a crucial dimension of American national memory and cultural history. Considering the huge body of historical literature on Salem witchcraft, I had assumed that another scholar would have already explored how the metaphor of Salem had had its own compelling history. In fact, historians have paid insufficient attention to the ways in which negative symbols have done what Jane Tompkins calls "cultural work." Although literary scholars have found much to investigate about Salem's life as a subject for a variety of imaginary literatures, historians have, for the most part, concentrated on investigating the events of 1692 in their most immediate context. ${ }^{10}$

Two treatments by literary scholars deserve special 
attention for the ways in which they have sought to illuminate the metaphorical uses of Salem. Philip Gould's 1995 New England Quarterly article, "New England WitchHunting and the Politics of Reason in the Early Republic," considers the career of Salem as political metaphor within a small but influential group of early national histories and works of fiction. Gould finds the language of such works "saturated" with terms like "fanaticism" and "delusion" and concludes that these descriptions expressed an anxiety specific to the Early Republic. ${ }^{11}$

This thesis challenges Gould's conclusions based upon research on the early narratives of Salem. Although evocations of "fanaticism" and the like by means of reference to Salem may have had cultural utility in the early Republic, their association with Salem witchcraft predated the texts he studies. By 1820, they were "old wine in new bottles." In contrast, Bernard Rosenthal's Salem Story entertainingly and incisively delineates the twentiethcentury life of Salem as a metaphor and as a subject of popular mass culture in the final chapter of a study devoted largely to the witch trials of 1692. Rosenthal is concerned mainly with the catalysts for the trials and the "layers of myth" which have obscured understanding of them and their participants. ${ }^{13}$ 
The absence of a body of literature to work within and against on the subject of Salem as metaphor has been daunting. My turn to other studies of the place of American symbols in national memory proved equally frustrating. While George Washington, Abraham Lincoln, the Pilgrims, Daniel Boone, and any number of events and individuals have received attention as historians have become increasingly interested in memory, Salem was a continually bad fit. For the topics that have received the most skilled and innovative attention were, without exception, those which had risen to iconic status as positive models in American culture. ${ }^{14}$

Since there were no close models for a project of this sort, I turned to a series of studies that helped me to locate crucial pieces of the Salem puzzle. Richard Slotkin's Regeneration through Violence and Michael Kammen's Mystic Chords of Memory have been especially important to understanding the broader political, social, and even economic forces that have preserved and promoted such symbols as the "Puritan," who entered American memory with the very heavy piece of baggage known as Salem witchcraft. Jill Lepore's The Name of War has been an important influence on my thinking of about the struggle over language, narrative, and the after-life of events in the 
collective imagination. I have wandered out of history and into literary theory with Jane Tompkins' Sensational Designs to borrow the idea that certain texts "offer powerful examples of the way a culture thinks about itself, articulating and proposing solutions for the problems that shape a particular historical moment."15 while Tompkins specifically addresses the "cultural work" of the American novel, the pre-professional historical literature of the nineteenth century occupied a middle ground between modern, archive-based scholarly historical studies and imaginary literature. Therefore, I would argue, Tompkins' observations can reasonably be applied to nineteenth-century histories, as well.

Finally, underlying the entire project is Anderson's vivid idea of an "imagined community" which was "tightly linked by print."16 Nineteenth-century histories provided Americans with the raw materials for a common imagined past. And they explicitly encouraged deriving lessons from their narratives that would illuminate contemporary problems. Historical examples likewise offered solutions for maintaining the bonds of the "imagined community" in which Americans lived. In the case of a positive symbol, as Richard Slotkin has said of the myth of Daniel Boone, the power of the invoked image lay in its ability "to serve as 
the embodiment of local values or cultural assumptions and as the vicarious resolver of the dilemmas that preoccupied that culture."17 Boone's example, then, suggested a course of action that the reader might emulate to strengthen or maintain the bonds of community in moments of crisis.

The metaphor of Salem, by contrast, resolved cultural dilemmas not by suggesting a course of action but by warning against one. It conjured up a widely understood historical event to articulate the inevitable consequences of an illadvised action---whether it was a dangerous religious innovation or the damage inflicted by abolitionist activity. Salem served to mark the boundaries of acceptable behavior and the threat that might imperil the continuation of an "imagined community".

To get at this story, I have relied upon a wide variety of print sources. They are, by necessity, crucial to tracing the cultural memory and use of Salem witchcraft in the nineteenth century. Barring published oratory, which may or may not accurately reflect the actual spoken version, ${ }^{18}$ it is nearly impossible to recapture the oral use of Salem witchcraft apart from the comments of witnesses to such speeches or by reference to responses in debates about oral remarks. The source that drew the largest audience is the printed text, although its true parameters can never be 
precisely known, particularly in the nineteenth century. My goal initially was to determine if Salem witchcraft even appeared in the nineteenth-century cultural record beyond a mention in history books and in fiction. I had hoped, if I found further references, to analyze the meanings attached to Salem at various historical moments. I lacked an obvious set of sources, such as the one that Fourth-of-July oratory might offer for a study of a patriotic symbol. I found my starting place, instead, by considering that salem or "witch-hunt" in our own day signaled controversy, and I therefore began to look for moments of deep conflict in earlier times. What I found in the nineteenth century was an abundant supply of examples in all types of print sources.

In fact, the sources for a project of this sort have turned out to be enormous. Therefore, it has not been my goal to be exhaustive but to instead gather a large number of appearances of Salem from the widest variety of sources. In this way, I hoped to trace the public life of Salem witchcraft as a historical symbol, to determine the reasons for its popularity as a metaphor, and to discern, as far as possible, its understood meanings in the past. The sources I have employed cover every genre from schoolbooks to newspapers, Congressional speeches, abolition oratory, 
pamphlets, novels, song lyrics, poetry, patriotic oratory, periodicals, drama, and many more. The only criterion was that Salem witchcraft, either implicitly or explicitly, be used as an illustrative metaphor.

If I have relied heavily upon the newspapers, textbooks, and periodicals which have the highest profile, such as the New York Herald, Samuel Goodrich's schoolroom histories, and DeBow's Review, it is because they had a large circulation and, therefore, probably the most influence. Within their time and place, they used an historical reference, disseminated it broadly, and thereby helped construct a broad understanding of Salem witchcraft. Comparing such references, I have found no significant deviation in usage in those sources appearing within the same time period, and, just as strikingly, much consistency in sources that address the same issues (such as religion or abolitionism)

In the interest of determining how broadly the metaphor of Salem was used, I have also deliberately sought out sources that were unpublished (at least in their own time) such as John Adams' diary entries and Samuel F.B. Morse's letters, as well as small special interest newspapers such the Civil War era Banner of Liberty. I have consistently sought to balance sources from those with the broadest 
distribution to those which received less attention. In many respects, as in my examination of school books, these choices offered, as Ruth Elson showed in her evaluation of their content, new ways of looking at how nineteenth century ideas were defined and circulated. Schoolbooks, in fact, form the nexus of print texts given their powerful role in advancing the Salem story in the nineteenth century. Chapter One considers the early days of Salem witchcraft's career as a cultural emblem by looking at common school texts (histories, geographies, and readers in particular) in the early national era. Deliberately created to assist in the creation of a republican citizenry after the Revolution, school textbooks stand as the "lowest common denominator"19 of American intellectual history. While schoolbooks have been under appreciated as historical documents in their own right, they illuminate the synergistic relationship between historical presentations of Salem, its representation in imaginary literature, and the ways in the language and ideas of witchcraft emerged in nineteenth-century cultural controversies. The nineteenth-century schoolbook version of Salem played a critical role in establishing the values and opinions of Americans. The form and method of these texts reveal much about Salem's role as a cultural symbol. Chapter Two carries the exploration of Salem 
witchcraft forward into the 1830s, as religious innovations that ranged from short-lived cults, to Spiritualism, Mormonism, and a host of other quasi-religious movements appeared on the American scene. In this context, oppositional literature proliferated. This controversial literature used Salem witchcraft metaphorically to express normative religious values. By invoking Salem, opponents of religious movements under question delineated their view of the limits of acceptable practice within a republic. Followers of such movements, by adopting alien doctrines and rituals and often following strong central leaders, were seen as having an attenuated sense of individualism that was caused by religious "fanaticism" or "delusions." Salem witchcraft was presented as a forerunner to such extremism that well illustrated the natural consequences of religious zealotry. Through religious controversies beginning in 1835 and continuing through the end of the nineteenth century, Salem witchcraft moved into the national consciousness as a cultural metaphor whose meaning centered on irrationality and excess.

Chapter Three focuses on the development of Salem witchcraft as a metaphor within the Southern rhetoric of sectional crisis from 1849-1860. As Southerners sought to distinguish their cultural traditions from those of the 
North, they revived the seventeenth-century Cavalier as a representative icon. The Cavalier's historical opponent, the Puritan, was gradually transformed into a New Englander who was deeply implicated in Salem witchcraft and who stood as a primary example of the aggressive tendencies manifest in "abolition fanaticism." This mythic structure allowed Southerners to create a historical point of origin for a separate regional identity as they rejected the long established national historical narrative of founding within which the historical Puritan was central. The appearance of the witchcraft metaphor within this political battle both propelled Salem into national usage and helped heighten the emotional tension within the sectional conflict.

Chapter Four traces the decline of the Puritan as a useful national symbol and his replacement by the far less controversial Pilgrim of Plymouth Colony. My study ends with the era of Civil War and Reconstruction by considering the toll on the Puritan symbol of harsh political rhetoric from the North and South. Amid the sectional crisis, Southern rhetoric used the metaphor of Salem witchcraft as an emblem first of the "fanaticism" of the abolitionists and then of an undifferentiated Northerner. During the war years, newspapers and journals with "Copperhead" or pro-Southern leanings adopted Salem, as well, this time as a way of 
emphasizing the need for "toleration" and to warn of the evils of "persecution." In the decades after the Civil War, new research on the Pilgrims of Plymouth Colony provided a serendipitous opportunity to transform the symbol of national founding from an intolerant to a tolerant settler. This well served the goal of white sectional reconciliation. My study closes with a discussion of how Salem persisted in American memory as a useful cultural metaphor. The answers, in part, lie in the ways in which Salem became embedded in an imaginary American past that could be, and was often, invoked to meet the cultural needs of nation building. 
Notes to Introduction

1 David Lowenthal, "Past Time, Present Place: Landscape and Memory," Geographical Review 65 (1975): 31 . For a discussion of the physical landscape of the city of Salem and its witch trials related locations, see: Kenneth E. Foote, Shadowed Ground: America's Landscapes of Violence and Tragedy (Austin: University of Texas Press, 1997).

2 On memory and culture in general see: Michael Kammen, Mystic Chords of Memory: The Transformation of Tradition in American Culture (New York: Vintage, 1993); Maurice Halbwachs, On Collective Memory (Chicago: University of Chicago Press, 1992); Michael Kammen, In the Past Lane: Historical Perspectives on American Culture (New York: Oxford University Press, 1997); Jill Lepore, The Name of War: King Philip's War and the Origins of American Identity (New York: Vintage, 1999); Wesley Frank Craven, The Legend of the Founding Fathers (Ithaca: Cornell University Press, 1965); and, David Lowenthal, The Past is a Foreign Country (New York: Cambridge University Press, 1985).

3 My own short narrative is drawn from the large body of modern scholarship which exists on the Salem witchcraft trials and to which the reader is directed for more information on the trials themselves. Some of the more recent and best analyses from a variety of perspectives include: Paul S. Boyer and Stephen Nissenbaum, Salem Possessed: The Social Origins of Witchcraft (Cambridge, Mass.: Harvard University Press, 1974.); David D. Hall, "Witchcraft and the Limits of Interpretation," New England Quarterly (1982): 253-81.; Jane Kamensky, Governing the Tongue: The Politics of Speech in Early New England (N.Y.: Oxford University Press, 1997.); Carol F. Karlsen, The Devil in the Shape of a Woman: Witchcraft in Colonial New England (N.Y.: Norton, 1987.); John Demos, Entertaining Satan: Witchcraft and the Culture of Early New England. (New York: Oxford University Press, 1982); Elizabeth Reis, Damned Women: Sinners and Witches in Puritan New England (Ithaca: Cornell University, 1997); and, Bernard Rosenthal, Salem Story: Reading the Witch Trials of 1692 (N.Y.: Cambridge University Press, 1993).

4 John Hale," A Modest Enquiry into the Nature of 
Witchcraft"(1702) in George I. Burr, Narratives of the Witchcraft Cases, 1648-1706 (N.Y.: Charles Scribner's Sons, 1914), 413.

6 There is generally some variety in the number accused in the region in 1692. I have taken this number from the recently translated letters of Jacob Melijn, a Dutch merchant who lived in Boston and was close to the Mathers and other prominent Puritans. He wrote to several people about the trials while they were underway and as they ended in 1692. Jacob Melyen, Letterbook, 1691-1696, American Antiquarian Society, July 11, 1692. Translation courtesy of Evan Haefeli.

7 For an analysis of these narrative additions and their consequences, see: Bernard Rosenthal, Salem Story: Reading the Witch Trials of 1692 (New York: Cambridge University Press, 1993)

8 Two of the most recent and best studies of the construction of American identity, see: Lepore, The Name of War; and, David Waldstreicher, In the Midst of Perpetual Fetes: The Making of American Nationalism, 1776-1820 (Chapel Hill: University of North Carolina Press for the Omohundro Institute of History and Culture, 1999).

9 Benedict Anderson, Imagined Communities, revised edition. (New York: Verso Books, 1996).

10 For considerations of Salem witchcraft in literature, see especially: David Levin, Forms of Uncertainty: Essays in Historical Criticism (Charlottesville: University Press of Virginia, 1992); Lawrence Buell, New England Literary Culture: From Revolution through Renaissance (New York: Cambridge University Press, 1986); Richard Slotkin, Regeneration through Violence: The Mythology of the American Frontier, 1600-1860 (New York: Harperperennial, 1996); James William Clark, Jr., "The tradition of Salem witchcraft in American literature: 1820-1870"(Ph.D. diss., Duke University);Rosenthal, Salem Story; and, Philip Gould, "New England Witch-Hunting and the Politics of Reason in the Early Republic." New England Quarterly 68 (1995): 58-82. For brief mention of the memory of Salem witchcraft in historical and cultural studies, see: Craven, The Legend of 
the Founding Fathers; Kammen, Mystic Chords of Memory; Ann Uhry Abrams, The Pilgrims and Pocahontas: Rival Myths of American Origin (Boulder, Colo.: Westview, 1999); and, Lowenthal, The Past is a Foreign Country.

11 Gould, "Witch-Hunting," 59.

12 Ibid.

13 Rosenthal, Salem Story, 10.

14 A selection of excellent studies of American memory includes: Robert S. Tilton, Pocahontas: The Evolution of an American Narrative (New York: Cambridge University Press, 1994); Michael Frisch. "American History and the Structures of Collective Memory: A Modest Exercise in Empirical Iconography, "The Journal of American History 75, no. 4 (March 1989): 1130-1155; Karal Ann Marling, George Washington Slept Here (Cambridge, Mass.: Harvard University Press, 1988); Merrill Peterson, The Jefferson Image in the American Mind (New York: Oxford University Press, 1970); John Mack Farragher, Daniel Boone: His Life and Legend (New York: Owl Books, 1992); Merrill Peterson, Lincoln in American Memory(New York: Oxford University Press, 1994); John Seelye, Memory's Nation: The Place of PIymouth Rock (Chapel Hill: University of North Carolina, 1998); Wilbur Zelinsky, Nation Into State : The Shifting Symbolic Foundations of American Nationalism. (Chapel Hill: University of North Carolina Press, 1988); David Thelen, "Memory and American History," The Journal of American History 75, no.4 (1989): 1117-1129

Is Jane Tompkins, Sensational Designs: The Cultural World of American Fiction (New York: Oxford University Press, 1985), xi.

16 Anderson, Imagined Communities, 64.

17 Slotkin, Regeneration, 313.

18 A good example of oratory which is often considerably different than the published version and which is used in this study, are the speeches made in Congress. Senators and Representatives regularly reworked their floor comments before submission to the Congressional Globe.

EIson, Guardians, 9. 
CHAPTER ONE

USEFUL KNOWLEDGE

In one of the most dramatic and memorable scenes in American literature, invited guests arrive at Colonel Pyncheon's newly completed house for a reception only to find their host dead from mysterious causes. Despite, or perhaps because of, the large crowd of witnesses, rumors and myths about Colonel Pyncheon's death instantly abound; they persist for generations. The rumors revolve around a possible link between his death and his role in the recent witchcraft trials. For popular belief held that the curse laid on Pyncheon by Matthew Maule at the hour of Maule's execution had finally been fulfilled. Condemned to death on Pyncheon's accusation of witchcraft, Maule cried out to Pyncheon as he faced the gallows - "God will give you blood to drink!" As they formed around the bright evidence of Pyncheon's final hemorrhage, public rumors conjured up details of violence done by a spectral hand. The most fantastic tale was the "fable of the skeleton hand, that the Lieutenant Governor was said to have seen at the Colonel's throat, but which vanished away, as he advanced farther into the room." Such a story, the reader was informed, might be the sort of "tradition which sometimes brings down truth 
that history has let slip" but, then again, it might be, as such things more commonly are, merely part of "the wild babble of the time." 1

The vignette is from Nathaniel Hawthorne's The House of the Seven Gables, and -- although neither Salem, nor the year 1692 is ever explicitly mentioned -- the curse itself might be familiar to a reader well-versed in Salem witchcraft history as that actually laid on minister Nicholas Noyes by the condemned Sarah Bishop. Certainly, the average reader who came upon the scene in the opening pages of the novel in 1851 would not have needed many details to instantly identify Hawthorne's historical allusion. For despite Nathaniel Hawthorne's complete identification with the use of Salem witchcraft as a fictional plot device, he was a late comer to the subject of Salem in the nineteenth century. In fact, to illustrate his tale of the destructive burden of the past on the present for readers in the nineteenth century, he could have chosen no better or more familiar theme than Salem witchcraft to frame his tragic story of the Pyncheon and Maule families. How the American reading public acquired this familiarity and what it meant not only for the fortunes of the author involved, deserves further scrutiny for the role of Salem witchcraft as a broader cultural metaphor. 
In his study of Salem's use as a political metaphor in the period from 1790 through 1830. Philip Gould asserts that these texts were written in a historical moment when contemporary political anxieties caused "the historical and literary treatments of Puritan witch-hunting... [to be] saturated with words such as 'bigotry' and 'superstition,' or 'zeal,' 'delusion,' and 'infatuation.'"2 To Gould, this "language of irrationality reflected the political and social anxieties rampant in the Early Republic. "3 To historians of the period, such as Jedidiah Morse and Hannah Adams, likewise, according to Gould, "the tragedy at Salem was a decidedly political event." ${ }^{4}$ These connections reflected the fact that Salem had indeed passed from lived experience to historical memory.

If, however, we look at a sampling of the histories published in London and the mainland colonies from 1738 through 1776, it is apparent that such representations of Salem predated the early national period. The histories contain the same provocative language Gould sees in the late eighteenth and early nineteenth centuries. These texts undercut Gould's argument that the cultural vocabulary used to describe Salem witchcraft had "densely layered and sometimes unstable meanings" that were unique to the culture of the Revolutionary period. ${ }^{5}$ Instead, while authors in the 
1790s through 1830s were involved in an ongoing process of finding their own "useable past" in Salem's episode of witch-hunting, it was a "past" which already had a presence in American history. ${ }^{6}$

The earliest histories to mention Salem rendered a harsh verdict on the witch trials. Salmon's Modern History, published in London in 1738, described the "zeal of the government;" George Chalmers in 1763 agreed, noting that "the court proceeded with the greatest zeal."7 Chalmers also observed that "delusions and impostors" were mistaken in Salem for the witches of Biblical times. ${ }^{8}$ John Whiting, in a 1776 account of a "popular madness" that involved the "imaginations of the people," noted that the town itself was "fanatically called Salem." In these eighteenth-century histories, whether published on the edges of living memory of the trials or on the eve of the Revolution, historians were in agreement that "a most horrid inhuman murder, by colour of law, was perpetrated upon many ignorant maniacs...called witches."10

Thus was the historian's version of Salem witchcraft fully invested with inflammatory language prior even to 1776. This was true also of an account by Thomas Hutchinson, the most influential historian of Salem witchcraft well into the nineteenth century. His 1750 History of 
Massachusetts would be the standard used by general and schoolroom historians in their "compilations" until the mid1830s. It was Hutchinson who provided the rendition of Salem used by historians in the early Republic---the same writers Gould argues arrived at their views from anxieties peculiar to the post Revolutionary period. Hutchinson described a "people...seized with gloom and horror" who, under the effects of either "infatuation," or "fraud and imposture" became "credulous" when charges of witchcraft began to circulate. What was most difficult for Hutchinson to understand in 1750, however, was the Puritan "bigotry" that would later be featured so prominently in the early national histories. "I know not how to excuse the persecution," he admitted, "when the charter granted toleration to all Christians, except Papists."11 History and literature produced in the early Republic might have found utility in the provocative language of early Salem witchcraft histories but they did not invent the style; they borrowed it.

As Americans began the cultural and intellectual project of nation building in the nineteenth century, the language that described Salem witchcraft and provided the lesson to be taken from the episode also entered the cultural vocabulary through imaginary literature. Jane Tompkins' consideration of the factors that converged to 
determine the reputation of nineteenth-century novels reinforces the conclusion that the histories of the era were important in shaping The House of Seven Gables and other Salem-witchcraft-based fiction. The celebrity of imaginary treatments of Salem witchcraft derived largely from their familiarity. The story of Salem witchcraft was one that was "instantly recognizable" to the reader and so operated as a "telegraphic expression of complex clusters of value." By serving as a kind of "cultural shorthand," Hawthorne's novel and the many lesser literary efforts that used Salem witchcraft served to "teach readers what kinds of behavior to emulate or shun."12 While in Tompkins' view novels are "agents of cultural formation" which "offer powerful examples of the way a culture thinks about itself,"13 they are part of a nexus of cultural documents that perform this duty. Within imaginary literature, we can see a variety of genres that invoke Salem witchcraft as a subject and that also do this cultural work.

In fact, authors of imaginary literature about Salem depended upon reader familiarity. This familiarity was gained most commonly in the nineteenth century from the textbooks produced for the schoolroom. The neglect of the schoolroom history and its role in framing the memory of Salem witchcraft in American culture obscures a powerful 
influence that joined nineteenth-century literature, history and memory. What Nathaniel Hawthorne did so successfully was to use this particular historical episode to explore the nineteenth-century preoccupation, in Lawrence Buell's words, with the inherent "gap between enlightened present and Puritan past."14 The gap was one that authors like Hawthorne tried to bridge with varying degrees of success. Salem witchcraft as a subject for creative literature has been called by literary scholar James Clark a "literary treasure trove -a rare deposit in historical memory which is simultaneously dark and heavy, though not nearly explained completely by established facts." 15 Clark dates the first literary treatment of Salem witchcraft to Jonathan Scott's 1817 epic poem "The Sorceress, or Salem Delivered." But, he quickly dismissed that piece from the canon of Salem witchcraft literature because it was too reliant upon English models rather than consistent with the "poet's American heritage and imagination," or even having the redeeming quality in his view, "of enduring popularity or interest."16 However, the fact that Scott thought to use Salem as a framing device at all indicates that he was sensitive to the dramatic potential of the episode and, perhaps, even its contemporary, if not "enduring," popular appeal. 
Scott's long forgotten poem was published early in a period when American writers were seeking native subjects to self-consciously create a specifically American

literature. ${ }^{17}$ Between 1817 and the publication of The House of Seven Gables in 1851, Salem witchcraft served as a subject for at least two stage plays, three novels, a variety of short stories, and several poems. Each focused on the dramatic elements inherent in a narrative that passed through accusations, jury trials, and public executions. ${ }^{18}$ Each also provided characters that exemplified a familiar theme---namely, individuals caught within a decisive historical episode that had figured prominently in the basic histories that had proliferated in the antebellum era. Each also concentrated on highlighting the gap Lawrence Buell has identified between the past and present. Marc Sargent labels this America's "pre-Revolutionary medieval side."19 Thus Salem has stood in American literature and history as a baseline event for measuring American cultural progress. The customary story of Salem witchcraft was made thrilling not only by skillful retelling but also by suggesting that the reader was always potentially at risk himself from a situation that would bring a recurrence of the "delusions" of a "superstitious" past. 
As the "the lowest common denominator of American intellectual history, "20 the schoolroom history, therefore, is a valuable historical resource in its own right. Such texts matter both for their content and because the manner of instruction popular in the nineteenth-century American schoolroom relied completely upon them. Schoolbooks universally did not just teach American children about the events at Salem in 1692; they provided explicit instruction as to what lessons were to be drawn from those events. Without exception, the nineteenth-century schoolchild was taught that Salem was a vestige of a superstitious and even foreign age that was alien to his own bright and progressive present. By 1851, most readers of the House of the Seven Gables would have been intimately familiar with the story of the Salem witchcraft trials that framed the lives of the novel's Pyncheon descendants. It was a story that would have resonated in the reader's own memory and imagination.

The substance of nineteenth-century American education, as David Hall argues, stemmed from a seventeenth-century belief that the "mythic significance of becoming a literate, catechized, and Bible-reading people was freedom from 'popish tyranny'."21 Free schools emerged first in New England out of the religious origins of the Puritan settlements. By the late eighteenth century, the 
Massachusetts Bay Colony's belief that educated children were also imbibing "at once political and moral...obedience to their superiors" was well established, ready to be refined and expanded into a national ideal. ${ }^{22}$ Toward that end, Elson argues, the political and social concepts that schoolbooks included highlighted "not necessarily universal truths but national truths." 23 For the average literate American, these books "delineated...an idealized image of both himself and of the history that had produced the admired American type." 24

Education in the post-Revolutionary era was specifically geared to educating men to citizenship and prodding women to encourage civic virtue in the same. ${ }^{25} \mathrm{~A}$ conscious effort was made to encourage the availability of free public schools as the primary vehicle for forging a "republican citizenry." ${ }^{26}$ Free common schools were provided as a means of establishing general authority as well as a common cultural foundation through the acquisition of "useful knowledge" and moral training. Benjamin Rush was among many who insisted that education along the proper principles would "render the mass of the people more homogeneous, and thereby fit them more easily for uniform and peaceable government. ${ }^{27}$ 
In 1827, Massachusetts was the first state to establish an Education Commission and a free public school system with educator Horace Mann as Secretary. It was also the first to require history as a subject in schools precisely because it was considered useful knowledge for the future citizen. ${ }^{28}$ In addition, Massachusetts had, by 1839, created a state Normal School for teacher training. ${ }^{29}$ other states were slower to set up formal structures for state oversight. Pennsylvania established such a system in 1834, Vermont in 1850, and Iowa in 1858 , for example. ${ }^{30}$ The Southern states had no longstanding tradition of public education at the town level and greater distances between settlements. Many were was "served by private academies" which, by 1850, enrolled some 70,000 white students. ${ }^{31}$

Noah Webster's assertion that "the virtues of men are of more consequence to society than their abilities"32 reflected a mind-set that dominated nineteenth-century classroom education and, more specifically, its classroom readers and histories. Indeed, as the demand for teachers out-stripped the supply of properly trained individuals, a reliance on textbooks came to define the American system of elementary education. Books would give the child the proper orientation toward this new social order. ${ }^{33}$ But a republican education for a republican citizenry required books with an 
appropriate ideology and a sense of America's singular destiny. Noah Webster reminded Americans that "it is the business of Americans to select the wisdom of all nations...to add superior dignity to this infant Empire and to human nature." ${ }^{34}$ A few European selections might be appropriate within readers, but the practice of importing books from Europe or reprinting them in America without alteration was clearly not compatible with providing the desired lessons. The few domestic texts in existence before 1815 were produced by ministers and "gentry scions" with a. literary bent whose education and social positions provided their own implicit credentials.

These popular school histories occupied an important place in American society. A speaker before the 1845 meeting of the New Jersey Teachers and Friends of Education spoke to their value in national life, by stressing that it is from

those unassuming companions of the schoolroom, and not from those more elaborate writings which grace the libraries of the men of wealth and the professional scholar, that the great mass of our citizens must ever derive their knowledge of the character, toils, and privations of our fathers, and the origin and nature of our free institutions. ${ }^{35}$ Ruth Miller Elson concurs with this evaluation in her study of nineteenth-century educational texts. She asserts that apart from the Bible, the books most widely read in America prior to the twentieth century were 
common elementary schoolbooks. The very fact argues for their importance within the culture. These were not written by intellectuals or those formally trained in the disciplines they covered, but most often by printers, schoolmasters, or simply by other literary entrepreneurs who saw in public school books a way to make a living. ${ }^{36}$

The period after the War of 1812, in particular, saw the rise of a class of self-made men in the literary sphere who offered as their credentials neither social position nor a college education but instead provided prefaces that located their volumes in the realm of disinterested public service. ${ }^{37}$ Despite this influx of non-elite and even poorly educated men and women to the ranks of authorship, schoolbooks remained profoundly conservative, stressing order, hierarchy, and moral training. Samuel Goodrich reassured parents that he did not think that "the moral advancement of society is greatly less [sic] than its intellectual."38 Goodrich, the master of the soothing passage, also was a firm believer in the moral progress of America:

if there are evils among us; if prejudices are indulged, and wrongs perpetrated by society, we may entertain the confident hope that they will ere long be obliterated, or at least softened by the united force of that intelligence and virtue which are now 
diffused among us and constitute the basis of public opinion. ${ }^{39}$

Not all observers were sanguine about the changes in authorship. By 1842, John Yeomans in his inaugural address at Lafayette College would complain at length that "books are rather made than written...the whole thing has become an affair of money-making. "40 Nevertheless, changes in commercial culture in the decades after the Revolution caused a shift in the production of schoolbooks as the democratization of literary culture reached into all areas of publishing.

Salem witchcraft as subject was ideally suited to the elementary schoolroom history which sought clear examples of virtue and vice. Compilers actively sought dramatic stories to illustrate the teaching of moral and civic lessons. While most authors such as Emma Willard, offered to "sow the seeds of virtue, by showing the good in such amiable lights, that the youthful heart shall kindle into desires of imitation," others such, as Charles A. Goodrich, suggested that "pictures of the vicious, ultimately overtaken by misery and shame" would serve as a stronger warning. ${ }^{41}$ Along with the language and symbols of desirable or normative moral behavior embodied in the illustrative episodes in these books, then, is the implicit or explicit countersymbol. Through these clearly drawn moral condemnations, 
schoolbooks also inscribed the boundaries of acceptable or desirable behavior and the signs by which to recognize upright citizens. Salem, while imbedded in celebratory narratives of Puritan founding, stimulated the moral imagination by pointing to the wages of excess and by celebrating the progress made since those olden times.

The schoolroom history, then, was likely to be not just a nineteenth-century American's first introduction to the story of the 1692 Salem witchcraft trials in print but often the last. If he happened to see Cornelius Matthew's drama "Witchcraft" in the 1820 s or read Harry Halyard's "The Haunted Bride" in the 1840 s or even Nathaniel Hawthorne's The House of Seven Gables in the 1850s, he would be likely to view those versions through the lens of his schoolbook histories just as the authors themselves undoubtedly formulated their treatments under the influence of their own early exposure to such texts. The fact that literature and history were more companionate genres through most of the century than competing narratives gave them a symbiotic relationship.

This mingling of history and literature was evident in the professional relationship between two of the most celebrated authors of nineteenth-century salem-related texts. In 1836, Nathaniel Hawthorne was fifteen years away 
from publishing the House of Seven Gables, which would forever link him in the American mind to the story of Salem witchcraft. His chronic financial problems had led Hawthorne to take on the editorship of The American Magazine of UsefuI and Entertaining Knowledge for the salary of $\$ 500.00$ per year. His tenure at the magazine was not a happy one. He repeatedly complained to his older sister Elizabeth that his employer, publisher Samuel Goodrich, was a sharp bargainer who had taken advantage of Hawthorne's desperate state and was ever "unscrupulous in money matters, and not particularly trustworthy in anything. " 42 Nor was Hawthorne happy with his editorial duties. "Concoct, concoct, concoct, I make nothing of writing a history or biography before dinner," he said bitterly. Elizabeth was well aware of the low wages involved in writing for hire for Goodrich. Yet in the midst of these epistolary complaints, her brother asked her to collaborate with him on another ghostwriting project for Goodrich. This was the new "History of the Universe" to be done under Goodrich's own pseudonym "Peter Parley." Nathaniel promised his sister the entire $\$ 100.00$ commission, although he allowed that it was a paltry sum for two who would call themselves "Historians of the Universe."43 In the seven years that Nathaniel Hawthorne had thus far been associated with Goodrich, he had written as 
"Peter Parley" or sold his own fiction for Goodrich's annual The Token for "less than 1.00 per page." Meanwhile, Goodrich became a wealthy man. When Hawthorne completed another Parley schoolbook in 1837, he stated his annoyance with Goodrich in even stronger terms. The publisher, who employed not only Hawthorne but also other celebrated nineteenth-century writers such as Catherine Maria Sedgwick, lived only, Hawthorne groused, to "feed and fatten himself on better brains than his own." 44

This literary contretemps is an interesting moment of intersection for several reasons. Although no one is more immediately associated in the modern popular mind with the memory of the Salem witchcraft trials than Nathaniel Hawthorne, no nineteenth-century American was more responsible for the nurturing of that memory than Hawthorne's erstwhile employer, Samuel Goodrich. Their joint and separate projects provided a narrative of the nation's past that advanced a compelling tale of Salem witchcraft to a receptive audience and invested that narrative with morality. The lessons that Hawthorne, his publisher, and other writers of schoolbooks advanced about Salem witchcraft were, upon close examination, identical, whether promulgated in fiction or in schoolroom histories. Salem witchcraft stood for an irrational and superstitious past from which 
the reader had mercifully escaped but that he or she must still strive to keep at bay. Perhaps Hawthorne himself summed up the fraught relationship between the nineteenthcertury American reader and author and the historical Puritan: "Let us thank God for having given us such ancestors; and let each successive generation thank him, not less fervently, for being one step further from them in the march of ages." 45

If Nathaniel Hawthorne stood at the center of fictional Salem studies in the twentieth century, men such as Goodrich occupied the center of the world of nineteenth-century histories that prepared the reader for his or her introduction to Salem witchcraft. Born in 1793 to a Connecticut minister and his wife, Samuel Griswold Goodrich became known to generations of nineteenth-century schoolchildren and their parents as "Peter Parley." Under this pseudonym, as well as his own name, Goodrich published over 170 juvenile non-fiction titles that ranged from histories of the United States to sea stories. While his elder brother Charles A. Goodrich received a Yale education, family fortunes dictated that the younger samuel would go no further than the local common school, after which he served as apprentice to a bookseller and printer. He expanded his participation in the literary marketplace to include the 
role of author in 1829 when he published a schoolroom geography. By the time of Goodrich's death in 1864, he had sold an estimated 12 million copies of his books in the United States alone. ${ }^{46}$

Goodrich's entry into the world of authorship was apparently part of a deliberate commercial strategy. Surveying the crowded publishing marketplace for new opportunities in 1819, Goodrich saw that "utilitarian works" such as Jedidiah Morse's adult and schoolroom geographies were proven bestsellers. ${ }^{47}$ An 1841 profile in the Southern Literary Messenger claimed that Goodrich only turned to writing schoolbooks when he was "foiled" in his attempt to find a suitable author to take on the task. But Goodrich's own 1857 Recollections makes no such declaration about a desire to underwrite another's work. ${ }^{48}$ In his memoir, Goodrich maintained that it was his hatred of the fantastical nature of juvenile literature which produced such "atrocious books" as the Mother Goose stories that inspired him to enter the juvenile non-fiction market. ${ }^{49} \mathrm{He}$ further asserted that such books were responsible for "much of the vice and crime in the world," as the child influenced by them was reduced to "their own debased moral standard."50 Whatever Goodrich's original rationale, and his own autobiography, for all its disclaimers, hints at more 
pecuniary than philanthropic motives, it was truly good business in the nineteenth century for an author of schoolbooks to represent himself "as an apostle of civilization." 51

Lawrence Buell affirms that Goodrich's authorial strategy had economic dimensions. To be the "harbingers of moral uplift" offered post-War-of-1812 publishing entrepreneurs like Goodrich a position from which to market their books. The postwar era saw the rise of "sub-elite literature" that included niche market magazines targeted to women and general market popular periodicals that featured such items as the Horatio Alger stories. The latter reflected the experience of Goodrich himself. By providing "a link between high and popular culture," the democratization of print culture changed the literary landscape of schoolbook production. This illustrates the idea that national identity is predicated on the widespread belief in an "imagined community." 52 While newspapers helped to create "a national and nationalistic political culture whose primary medium was print, "53 schoolbooks were part of a nexus of print texts that helped Americans define themselves. Geographies of the United States, which emerged first, performed an act of intellectually taking possession of the nation. Once the individual and his neighbors were 
fixed physically in space, histories followed as first appendices to geographies and finally as separate volumes to fix the nation and its people both in time and in the imagination. ${ }^{54}$

As a self-consciously formed political nation founded in revolutionary separation and in the age of Enlightenment, Americans found history a vital part of such "useful knowledge." In such a situation, schoolbooks were called upon, as Ruth Elson explains, to perform "a function required in few other societies" in the early nineteenth century. With the formation of a new political nation "the American had to set up social patterns afresh and Iind his place in them." Such literary efforts could be considered, in the first decades after the Revolution, an intellectual form of taking possession of the nation. Schoolroom histories gave the American child the past as a frame of moral reference as it did the cultural work of providing him with a past that also served the future. As Elson observes, although the authors saw themselves as "guardians of liberty, they can be more accurately be described as guardians of tradition." 55

In this context, Salem witchcraft loomed large in didactic nineteenth century literature. Salem and other tales of colonial backwardness were included in virtually 
all of the elementary histories because they provided an opportunity for clear moral lessons that most authors considered the overriding imperative of childhood education. In addition, entrepreneurial schoolbook compilers recognized what writers of fiction were also learning in the early decades of the nineteenth century: the discussion of Salem witchcraft sold books.

The accounts of Salem witchcraft in many of these books simply borrowed the passages relating to the episode from Thomas Hutchinson's 1760 History of Massachusetts. For the fact that men and women with limited educational opportunities themselves could author books for the classroom reflected a method of writing and an appetite for self-improvement in the general society. Many authors, like Hannah Adams or Samuel Goodrich, referred to themselves as "compilers."56 Compiling consisted of what was essentially wholesale adoption, with little or no abridgment or modification, of other texts on various subjects. As author Benson Lossing plainly stated in his preface: "we freely appropriated to our use the fruits of the labors of others." 57

Thomas Hutchinson was a great favorite of the compilers because of his skepticism about witchcraft and his fearlessness in condemning the whole business. Consider his 
concluding remarks about the character and fate of the accusers:

None of the pretended afflicted were ever brought upon trial for their fraud, some of them proved profligate persons, abandoned to all vice, others passed their days in obscurity or contempt. ${ }^{58}$

Such remarks were deployed to support the standard schoolbook sense that "the misfortunes of men [are] mostly chargeable on themselves."59 With a strong sense that evil done brought evil in return, schoolbook authors regularly warned children against vice, lest it lead to ruin or death. ${ }^{60}$ Bad behavior was depicted as willful and a result of bad character or overindulgence. The children of Salem, wrote Salma Hale in 1825, were "hardened by impunity and success" as they expanded their circle of accused persons. ${ }^{61}$ In Thomas Hutchinson's version, the author observed that although some in the present day might think that mental disorders, or "bodily disorders that affected the imaginations," were to blame for the outbreak, he did not. For however "kind and charitable" this sort of belief might be, in the end, there could be only so much "winking the truth out of sight." 62

Hutchinson's distaste for the episode and his disapproval of the methods of investigation and trial were popular with schoolbook compilers. Especially effective, judging by how often it appeared in other versions, was 
Hutchinson's description of the conditions that precipitated the initial charges of witchcraft. In Puritan Salem, the "minds of people in general were seized with gloom and horror."63 His open disgust about the fact that "children, not twelve years old, were allowed to give their testimony" ${ }^{\prime 64}$ appealed to the schoolbook authors who wished to remind children of their subordinate position in society. Indeed, the inculcation of a social hierarchy was a recurring theme in the schoolroom histories. If the 1760 Hutchinson text read like an early nineteenth-century analysis of the events, it was because his narrative was repeated so frequently with and without alteration that his often was the early nineteenth-century version. Hutchinson never completely disappeared, but he was dethroned by George Bancroft in the late 1830s. Bancroft not only provided a more dramatic narrative, but also succeeded "primarily because he was able to enunciate with conviction, elegance, and learning" what nearly everyone already believed."65

A chapter entitled "Witchcraft at Salem," in Bancroft's History of the United States deftly synthesized earlier accounts that ranged from the seventeenth-century trial commentary through Thomas Hutchinson's 1750 history. Bancroft liberally applied the familiar language attached to Salem witchcraft as he judged the trial and its participants 
harshly on every line. Witnesses in Bancroft's version "told stories yet more foolish than false" while Samuel Parris, the town's minister, operated not from belief in witchcraft, but out of "special hatred" and "blind zeal."166 Confessions were sought by the "malice" of ministers on behalf of "angry" neighbors. Especially at risk for accusation in Bancroft's version were those who were "uninfected by superstition." ${ }^{67}$ Those accused who confessed merely followed what had been "hinted" at causing "the gallows...to be set up, not for those who professed themselves witches, but for those who rebuked the delusion."68 Parris, the target of most of Bancroft's ire, pushed for the execution of one woman the jury had doubts about because, according to the historian, "She must perish, or the delusion was unveiled." Massachusetts, was saved in Bancroft's history, not by the law which was "the English law, word for word as it stood in the English statute book" disenthralled, and asserted itself."71 It was the people who

employing a gentle skepticism, eliminating error, rejecting superstition as tending to cowardice and submission, cherishing religion as the source of courage and the fountain of freedom, the common mind in New England refused henceforward to separate belief and reason. ${ }^{72}$ 
George Bancroft's version of the Salem story tied American common sense and progress to the overthrow of English influences and did so in vivid and unequivocal terms.

Indeed, Salem well served a central purpose of school histories -namely, the telling of an exciting and memorable story to illustrate a moral lesson. Historian Charles Carpenter asserted that the "Peter Parley" books were the first to become nationally popular and that they did this by "dwelling especially on destructive snow slides, earthquakes and any sort of disaster."73 That "much of the material...[was] pure fiction, "74 caused few if any complaints. The point of the schoolroom histories and readers, or even education itself, was the training of character by example. As educator Emma Willard stated, "moral improvement is the true end of intellectual improvement."75 In fact, book sellers' catalogues highlighted as a selling point the fact that writers like Noah Webster sought specifically American "sentiments of liberty and patriotism" in order to "advance the happiness of [his] country."76 Unsigned quoted testimonials in Carter, Hendee, and Company's 1832 catalogue praised the "Peter Parley" books for their "vast amount of valuable matter" and Charles Goodrich's "lively anecdotes and narration" as key 
to its current fortieth printing and its adoption by Boston High School. ${ }^{77}$

The wide popularity of the books in antebellum America cannot be doubted. Reviewers often praised them; the American Annals of Education which judged Tales of Peter Parley about America, one of Goodrich's easiest historical readers, in 1829, to be a "useful" and "attractive introduction to more advanced stages of education." 78 If the reviewer had any concerns at all about the contents of the volume, they were limited to the woodcut illustrations, which emphasized "cruelty and suffering." He suggested the use in future editions of those with "happier associations."79 Still, Goodrich's account of his national tour in 1846 provides a measure of the popularity of the "Peter Parley" series among schoolchildren and their parents, as crowds flocked to see the author at every stop, even in the South, which had few public schools. Although he personally enjoyed "the soothing flatteries" of his fans, he did wonder about his "permanent place in literature."80 Nineteenth-century schoolbooks such as Goodrich's emphasized progress. However, there is little in the story of Salem witchcraft that seems to lend itself to a national narrative promising "future greatness." But if we consider the role that Salem played in these histories and the way in 
which it was described and analyzed, we can see that it supports national aspirations by providing a baseline for American progress. Certainly some accounts fulfill Charles Goodrich's desire for instructive scenes where the "vicious [are] ultimately overtaken by misery and shame."8I Hannah Adams claimed, for example, that finally "the whole country became sensible of their mistake, and a majority of the actors in this tragedy, expressed sincere repentance of their conduct." 82 But even in these minority versions which anachronistically suggest that the seventeenth-century inhabitants of Massachusetts Bay Colony suddenly threw off belief in witchcraft and indulged in wholesale regret, the message was of America's move towards greater liberty.

Most books emphasized that the child lived in a better age than did his or her counterpart in 1692 Salem. Erances Lister Hawks, writing as "Uncle Philip" told the reader of his schoolroom history that "your Uncle Philip has too much sense to believe in magic, charms and witchcraft." ${ }^{83}$ John Hinton mourned the Puritan lack of knowledge about "the structure of the human mind" which provoked such outbursts of passion." John Olney cautioned that "we must remember, that this was an age of superstition." 85 The authors of the elementary schoolroom texts were especially enthusiastic about including the subject of Salem witchcraft because it 
provided such opportunities to draw strong parallels between the past and present. Samuel Goodrich in his First Book of History for Children and Youth promised his young readers "the most amusing and instructive portions" of history and proceeded to tell them how children in Salem "pretended" to see evil manifestations and caused people to hang "for a crime that was only imaginary. ${ }^{86}$ He ultimately reassured his young audience that "we... know there is no such thing as witchcraft." ${ }^{87}$ Schoolbooks generally followed this model of providing accounts which reserved a full understanding of Salem and its tragedy for the more enlightened and more progressive nineteenth century reader. Samuel Goodrich gave one variation of a common theme when he reminded children that "it was a common error of that age" to believe in witchcraft. And still, he went on, "we cannot but wonder that our ancestors should have believed in it, and that many persons should have been hung, for a crime that was only imaginary." 88 Charles A. Goodrich informed his readers that "at this period, the actual existence of witchcraft was taken for granted." $89 \mathrm{~J}$. Olney in his 1851 history made the same point when he explained that although it "is astonishing to us that our forefathers with all their learning should have been thus deluded... we should remember that this was an age of superstition." 90 
Authors were also in agreement that Salem witchcraft was a result of such things as "manias," "delusions," "infatuations," "excitements," and other similar terms that imply a loss of reason. Abiel Holmes wrote that Salem "furnishes an affecting proof of the imbecility of the human mind, and of the powerful influence of the passions." 91 William Grimshaw's history described "an agitation, a terror in the public mind...driving the people to the most desperate conduct."92 The "spirit of the age:" an "intolerant spirit," an "age of superstition," or "the prevailing credulity of the age," all worked on "minds not sufficiently enlightened by reason and philosophy" to produce the "popular delusion" that was Salem witchcraft. ${ }^{93}$ But the desire to excuse the Puritan colonists for the episode of Salem witchcraft as a seemingly backward practice typical of the time often ran up against the competing nineteenth-century desire to condemn such practices in peculiar ways. While olney cautioned the child to remember the historical context in which Salem occurred, he, like most other authors, then undermined his case when he emphasized that as soon as the accusations moved up the social ladder to the families of magistrates they "began to suspect it was all a delusion...the witches soon fled."94 In John Howard Hinton's 1843 history the same "shock roused 
them to reflection." 95 "When "the best people in the country" were accused, Grimshaw's 1832 history reported, "suspicion was aroused."96 A few schoolbooks, such as Salma Hale's, explained that belief in witchcraft was due to the "infatuation" or "disordered imagination" of the time. But he later changed his tune. In closing his account, Hale claimed that "impostors" had made up the accusations -a charge that contradicted his earlier assertion that the trials at Salem emerged from the prevailing beliefs of their day. ${ }^{97}$

All the histories struggled to balance a portrait of the Massachusetts Bay Colony Puritan as the fountain of all American virtues with an accounting of Salem. In essence, the compilers saw history in the same way as did Thomas Jefferson. History was "the lamp of experience" that lit the way toward the liberty that would throw off "the dead hand of the past." Indeed a few, like Frederick Butler, who gave the Puritans unstinting credit for laying "the foundation of the United States of America," in his 1821 history, found the witchcraft episode so "disgraceful" that he wished it "buried forever in oblivion." 98 But even Butler did not have the temerity to completely eliminate reference to an historical episode that had "become a subject of public notoriety." 99 His method was to wash his hands of it 
completely while directing readers who felt compelled to know more about it to consult Thomas Hutchinson's History of Massachusetts. Charles Prentiss wished "in silence and sorrow, to pass all notice" of Salem but found that "truth and impartiality compel us, most reluctantly, to give a very brief account."100 But Prentiss and Butler were decidedly in the minority until history textbooks began in the 1880 s to drop the colorful stories of the past, with an explicit moral lesson, in favor of an emphasis on straightforward political narratives. The overwhelming choice of the schoolroom historians who wrote before the 1880 s was to negotiate the problem of praising the Puritan for national founding while taking on the problem of Salem witchcraft. Even authors who excused the Puritans for being victims of "the spirit of the age" chastised the witch hunters, though often by blaming English influences. ${ }^{101}$ The most interesting conclusion, however, comes in one of the books of the $1880 \mathrm{~s}$. John Ridpath defended the Puritans despite their "excesses" as without them, "America would have been a delusion and liberty only a name."102

School histories used the Puritan past as a foundation for American virtue and progress and depicted the colonist implicitly as "American" throughout accounts of heroic action, whether the protagonist was a resident of "Delaware" 
or "New England." Salem witchcraft as a topic, however, implicitly shifted that relationship to accent a more complex identity within many of the books. The most popular schoolroom histories from the late eighteenth through the mid-nineteenth centuries demonstrate this phenomenon. Noah Webster, in the historical section he contributed to Jedidiah Morse's popular The American Geography in 1789, reminded readers that Salem witchcraft was "the practice of the courts" and "was regulated by English law and custom."103 Hannah Adams did the same in her 1807 abridgement of The History of New England. ${ }^{104}$ Samuel Goodrich stressed to his readers that witch-hunting "was not an invention of their own. They received their notions from England."105 Even when New England colonists were not reported to be directly under the influence of English customs or law, children were instructed that witchcraft persecutions were "common in Europe for centuries" and that, as sorrowful as the twenty executions at Salem were in this one instance "thousands were executed in England and other countries" contemporaneously with the Salem outbreak. ${ }^{106}$ And so, in the case of New England, John Howard Hinton sniffed, "neither England nor any other nation is entitled to cast the first stone at them."107 
Since the method of instruction in schools through most of the nineteenth century was rote memorization, the inculcation of the "lesson" of Salem was not only effective but also permanent, if we can believe Daniel Fenning's statement to parents and teachers in his 1799 speller. Fenning promised that early instruction was important as "the mind of the child is like the soft wax to receive an impression, but like the rigid marble to retain it."108 This pedagogical approach insured that a child would not only memorize the facts about Salem witchcraft, but also he would memorize the moral lesson in vivid language. The problem of imperfectly or poorly educated teachers caused a reliance on a catechistical approach. ${ }^{109}$ Children were expected to answer such questions as: "What were the effects of this delusion?" "What strange delusion seized upon the minds of the people?" "What is now thought by people of America on the subject of witchcraft?" "How many executed?" "What of the delusion elsewhere? In Europe?" "Was belief in witchcraft general in that age?"110 The "correct" answer was the appropriate passage in the text. The constant repetition of themes of "delusion," "infatuation," and foreign origins for the witchcraft episode are striking. They were coupled with an insistence that a "season of error and persecution" defined the Salem experience. That message appeared in fictional 
accounts and in the many metaphors that were to be employed throughout the nineteenth century to equate deviant behavior with Salem witchcraft.

What is striking about the story of Salem and the schoolbooks is how static it remained over time. The boy of 1820 could easily find the same version he read in grade school in a later printing -for instance, in his grandson's schoolbook of 1860. Although the post Civil War era saw a new crop of schoolbooks whose view of what constituted "useful knowledge" or desirable narrative elements changed, the persistence of older editions in schoolrooms kept the antebellum versions alive and doing their cultural work right up to the end of the century. This uniformity over time more firmly embedded the language of a particular view of the events of 1692 in the American mind just as the method of instruction reinforced the details of the lesson. The twelve million or more "Peter Parley" volumes sold in America alone included full accounts of Salem witchcraft in the various histories and in the non-fiction "Tales" series, which testifies through sheer numbers to its influence. When one considers that untold numbers of family members and neighbors used the same copies for generations, the potential influence of the schoolbook versions increases all the more. The establishment of Salem witchcraft as a subject 
for study and as an exemplar of moral behavior pre-dated even the forgotten literary treatments that began in 1817 and certainly those that reached a larger audience in the 1830s-1850s. But similar narration of events and the didactic lessons to be learned about the progress since 1692 in both literature and history makes it easy to see why a relatively minor historical event persisted in the national imagination.

It was not Salem witchcraft as an event that nineteenth-century Americans wished to distance themselves from, as much as what it represented through relentless moral lessons handed down for generations. Salem witchcraft represented superstition, backwardness, and delusion. As such, it was a critical failure of progress and of reason. By the time that Salem's witchcraft trials became a common fictional subject in the mid-nineteenth century, generations were primed to understand the implications in the plot. When anxiety about the course of a new cultural movement or political controversy arose, the average American did not have far to go to find a handy historical parallel to express quickly and completely the range of his fears on the matter. If the concern threatened his sense of himself as part of a society that was moving forward toward greater reason and order, Salem witchcraft functioned well as a 
universally familiar shorthand for the costs of sliding backward into a world of irrationality and superstition. Ultimately, in the schoolroom histories, Salem witchcraft expressed a fear of the dead hand of the past as profound and as threatening as that rumored to have been seen at the throat of old Colonel Pyncheon. That preconditioning of the reader made The House of Seven Gables familiar, exciting, and Nathaniel Hawthorne's best-selling novel. ${ }^{111}$ Hawthorne gave the reader a vicarious thrill by bringing the threat of Salem forward into the lives of contemporary descendants of the original trial participants. others involved in public controversies over political and religious issues also raised the contemporary specter of Salem as not a vicarious, but as a real and immediate threat. As Salem emerged in these battles (often fought in print) it became established in the national imagination as an effective illustrative metaphor that expressed American fears of various domestic threats to their faith in reason and progress. It did so with the language and ideas of the schoolbook, which provided "useful knowledge" and a bridge to a distinctive American memory. 
Notes to Chapter One

${ }^{1}$ Nathaniel Hawthorne, The House of the Seven Gables (New York: The Modern Library, 2001), 16.

${ }^{2}$ Philip Gould, "New England Witch-Hunting and the Politics of Reason in the Early Republic." New England Quarterly 68 (1995): 58-82.

3ibid., 59 .

${ }^{4}$ Ibid., 64.

${ }^{5}$ Ibid., 81.

"Van Wyck Brooks, "An Unusable Past," The Dial (January 1923), 1 .

${ }^{7}$ Mr. Salmon, Modern History; Or, The Present State of AlI Nations, vol. 31 (London: n.p., 1738), 305.

${ }^{8}$ Ibid.

'John Whiting, The History of North and South America, vol.1 (London: n.p., 1776), 97.

${ }^{10}$ William Douglass (M.D.), A Summary, historical and political, of the First Planting, Progressive Improvements, and Present State of the British Settlements in NorthAmerica (Boston: 1749), 449.

11 Thomas Hutchinson, The history of Massachusetts: from the first settlement thereof in 1628, until the year 1750. 2 vols. $3^{\text {rd }}$ edit. (Salem, Mass.: Thomas C. Cushing, for Thomas and Andrews, Boston., 1795). Quotes in order: 19, 30, 63, $19,11$.

${ }^{12}$ Tompkins, Sensational Designs, xvi-xvii. Tompkins uses Nathaniel Hawthorne as a case study in how canonical status is often determined more by social connections and opportunities than the works' intrinsic merit. I do not disagree with her conclusions on that point. I do assert that the conditions she finds important for the reception of a literary work by the public in its own time also peculiarly benefited Hawthorne. Salem witchcraft, unlike, say, the Indian wars of western Massachusetts, has remained in the national imagination and so, therefore, Hawthorne's work has benefited in additional ways by pleasing not only the guardians of the canon, but successive generation of readers for the same reasons it did upon publication in 1851. 
${ }^{13}$ Ibid., $x v i i$ and $x i$.

${ }^{14}$ Laurence Buell. New England Literary CuIture: From Revolution through Renaissance (New York: Cambridge University Press, 1986), 250. Buell also discusses at length the 1857 novel by Josiah Gilbert Holland The Bay Path which transplants the story of Salem witchcraft to western Massachusetts and which is based closely on Holland's research for his non-fiction History of Massachusetts published in 1855. For an analysis of Hawthorne's attitudes toward the Puritan past, see: Michael Colacurcio, The Province of Piety: Moral History in Hawthorne's Early Tales (Cambridge, Mass.: Harvard University Press, 1984).

15 James William Clark. "The Tradition of Salem Witchcraft in American Literature, 1820-70" (Ph.D. diss., Duke University, 3.

${ }^{16}$ Ibid.,93. His claim that "Salem Witchcraft: An Eastern Tale" published in the New York Literary and Belles-Lettres Repository arose "without precedent in the literature of America" is obviously incorrect in light of Scott's poem.

${ }^{17}$ The studies of the development of Salem witchcraft as a subject for fiction and other literary genres are many. As one of the first domestic subjects for a nascent national literature in the early nineteenth century, Salem witchcraft has been considered within most of the general literary histories and within many of the specialized studies of the work of the authors of Salem-related literature. The best of these studies in an over-view vein are: Lawrence Buell's New England Literary Culture and Richard Slotkin, Regeneration through Violence: The Mythology of the American Frontier, 1600-1860 (New York: Harperperennial, 1996). Other useful studies that focus upon either the general evolution of Salem witchcraft as a literary theme or examinations of specific repeating elements of the episode in American literature include: David Levin, In Defense of Historical Iiterature: Essays on American History, Autobiography, Drama, and Fiction (New York: Hill and Wang, 1967); James William Clark, "The Tradition of Salem Witchcraft in American Literature, 1820-70"; and, Philip Gould, "New England Witch-Hunting."

${ }^{18}$ Examples of these include the novel by Eliza Buckminster Lee, Delusion; or, The Witch of New England (Boston: Hilliard, Gray, and Company, 1840); a novel published under 
two different titles by William L. Stone, The Witches: A Tale of New England (Bath, New York: R.L. Underhill, 1837) and Mercy Disborough (Bath, New York: R.I. Underhill, 1844); the novel credited to a likely pseudonym "Harry Halyard" titled The Haunted Bride: or, the Witch of Gallows Hill. A Romance of the Olden Time. (Boston: F. Gleason's Publishing Hall, 1848); stage plays include: Cornelius Mathews' "Witchcraft; or, the Martyrs of Salem" produced in 1846-47; and, "Superstition" by James Nelson Barker produced in 1824. ${ }^{19}$ Quoted in James D. Hartman, Providence Tales and the Birth of American Literature (Baltimore: Johns Hopkins University, 1999), 44 .

${ }^{20}$ Ruth Miller Elson, Guardians of Tradition: American Schoolbooks of the Nineteenth Century (Lincoln: University of Nebraska Press, 1964), ix.

${ }^{21}$ David D. Hall, "Readers and Writers in Early New England," in Hugh Amory and David D. Hall. The Colonial Book in the Atlantic World, vol. 1 (The American Antiquarian Society and Cambridge University Press, 2000), 121.

${ }^{22}$ Ibid., 121.

${ }^{23}$ Elson, Guardians, 2.

${ }^{24}$ Elson, Guardians, vii. Frances Fitzgerald also finds much of the same orientation in the schoolbooks of the late nineteenth and early twentieth centuries. She does, however, claim that the fact that textbooks "now hint at a certain level of unpleasantness in American history" is a recent phenomenon. It is not. Nineteenth-century schoolbooks page for page feature more death, disaster and condemnation of historical actors than any contemporary volumes. They are, however, less likely now to claim that misfortune is either divinely directed or a result of weak character. See: Frances Fitzgerald. America Revised: History Schoolbooks in the Twentieth Century (New York: Vintage Books, 1980), 9. ${ }^{25}$ Carl F. Kaestle, Pillars of the Republic, 1780-1860 (New York: Hill and Wang, 1983), 5. On the value of education to a republican form of government, see also: Jonathan Messerli, "The Columbian Complex: The Impulse to National Consolidation," History of Education Quarterly 7 (Winter 1967), 421; David B. Tyanck, "Forming the National Character: Paradox in the Educational Thought of the Revolutionary Generation," Harvard Educational Review 36 
(Winter 1966); and Noah Webster, "The Education of Youth" (Boston: n.p. 1790).

${ }^{26}$ On the importance of education in early national America and the nationalist orientation of schoolbooks see especially: Elson, Guardians; Waldstreicher, Perpetual Fetes; and, Melvin C. Yazawa, "Creating a Republican Citizenry," in Jack P. Greene, ed., The American Revolution: Its Character and Limits (New York: New York University Press, 1987).

${ }^{27}$ Benjamin Rush, "Of the Mode of Education Proper in a Republic," in Dagobart D. Runes, ed., The Selected Writings of Benjamin Rush (New York: Philosophical Library, 1947), 92 . Rush's ideas are very similar to Noah Webster on this issue. ${ }^{28}$ David Van Tassel, Recording America's Past: An Interpretation of the Development of Historical Studies in America, 1607-1884 (Chicago: University of Chicago Press, 1960), 90 .

${ }^{29}$ Elson, Guardians, 9. She also notes that by 1860 there were only twelve nationally with six in New England and six private concerns run by churches.

${ }^{30}$ Ibid., 5.

${ }^{31} \mathrm{John}$ McCardell, The idea of a Southern Nation: Southern Nationalism, 1830-1860 (New York: W. W. Norton, 1979), 179. $32{ }^{32}$ Noah Webster, A Grammatical Institute of the English Language... (Hartford: Huntington and Hopkins, 1784), 14. Italics are his.

${ }^{33}$ Kaestle, Pillars of the Republic, 17-18. 34 Webster, A Grammatical Institute, 14.

${ }^{35} \mathrm{M}$. Wilson, "Review of American Common School Histories," The Biblical Repository and Classical Review, $3^{\text {rd }}$ ser., no.3, vol. 59 (July 1845), 517. Wilson says that the eight most popular nationally are: Hale, Frost, S. Goodrich, C. Goodrich, Willard, Olney, Grimshaw, and Webster. This together with other sources that mention each frequently (particularly the Samuel Goodrich books) determined my special attention to them in this chapter.

${ }^{36}$ Elson, Guardians, 9. See also: Charles F. Heartman, The New England Primer...a Bibliographical Checklist (Metuchen, N.J.: Charles F. Heartman, 1922), xvii. Heartman says that 
elementary-level primers and schoolbooks were, along with the Bible, the 'stock book' in the bookshops of the towns and the general stores of the village." A quantitative analysis of the best selling school histories between 1821 and 1861 in the United States named: Hale, Charles Goodrich, Samuel G. Goodrich, John Olney, Emma Willard, and Marcius Willison. Charles Goodrich's History of the United States went into 44 editions selling an estimated 150,000 in the first ten years it was in print. See: Rolla M. Tryon, The Social Sciences as School Subjects, (New York: Ginn, 1935).

${ }^{37}$ Buell, New England Literary Culture, 41-2 for a general discussion of the shift in authorship and the emergence of popular literature. Quotes from page 41.

${ }^{38} \mathrm{~S}$. Goodrich, Lights and Shadows of American History (Boston: Bradbury, Soden, and Co., 1844),17. For similar introductory or prefatory statements stressing moral development, see also: C. Goodrich, History, 3; Willard, History, 5; and, Lyman Cobb, Cobb's Juvenile Reader, No. 3; Containing Interesting, Historical, Moral, and Instructive Reading Lessons... (St. Clairsville, Ohio: Horton J. Howard, 1836), 1 .

${ }^{39}$ Goodrich, Lights and Shadows, 18.

${ }^{40} \mathrm{John}$ Yeomans, "Address delivered in Easton, Pennsylvania, August $18^{\text {th }}, 1841$, on the occasion of the Author's

Inauguration as President of Lafayette College," The Princeton Review, 14, vol.2, 218.

${ }^{41}$ Emma Willard. History of the United States, or the Republic of America (New York: White, Gallagher, and White, 1828), n.p. "Introduction." Charles A. Goodrich (Rev.). A History of the United States of America, on a Plan Adapted to the Capacity of Youths. $35^{\text {th }}$ edition (Boston:

Richardson, Lord, and Holbrook, 1832), 3. The first edition was published in 1823 but, as will be seen in succeeding sections of this chapter, these books changed little if at all over time beyond the occasional appending of new material at the end of the volume.

${ }^{42}$ Nathaniel Hawthorne to M. [Elizabeth] Hawthorne c. 1836 not dated quoted in James $R$. Mellow. Nathaniel Hawthorne in His Times (Baltimore: Johns Hopkins University Press, 1980), 73. For an evaluation of this on-going relationship as well as Hawthorne's life-long financial woes, see also: Laurence Buell, New England Literary Culture: From 
Revolution through Renaissance (New York: Cambridge University Press, 1986); and, Newton Arvin Hawthorne (New York: Russell \& Russell, 1956). For a discussion about how Hawthorne's personal difficulties related to both his personal and commercial connections and the impact of that upon his literary reputation, see Tompkins, Sensational Designs, 32-37.

${ }^{43}$ Nathaniel Hawthorne to Elizabeth Manning Hawthorne January 25, 1836 and Nathaniel Hawthorne to Elizabeth Manning Hawthorne undated c.1836. He suggested that they take the assignment as the nature of the work was "so much less difficult" than standard magazine article writing.

44 Nathaniel Hawthorne to Elizabeth Manning Hawthorne, Letter July 1837 quoted in: John A. Garraty and Mark C. Carnes, general editors. American National Biography. (New York: Oxford University Press), 9:265.

${ }^{45}$ Nathaniel Hawthorne, "Main Street" in Twice Told Tales (Boston: Ticknor and Fields, 1854), 1. Check this cite

${ }^{46}$ This estimate is from the American National Biography entry "Samuel Griswold Goodrich." Goodrich's own estimate was 7 million, 265. For Goodrich's own sales estimate, see: Samuel G. Goodrich, Recollections of a Lifetime (New York: Sheldon and Company, 1864), 240.

${ }^{47}$ Ibid.

48"Samuel Griswold Goodrich," Southern Literary Messenger, October 1841, 736-39. The writer points out that this "silent progress" in schoolbooks wrought by Goodrich might have been missed while in "the last fifteen years, public attention has been chiefly engrossed by political and commercial revolutions." 736.

49 Goodrich was not the only author concerned with talking animals in juvenile literature. Lyman Cobb in his 1836 reader calls such things "which never did, and which never can take place... destructive of truth and morality." See: Lyman Cobb, Juvenile Reader No. 3: containing Interesting, Historical, Moral and Instructive Reading Lessons... (St. Clairsville, Ohio: Horton J. Howard Publisher, 1836), 1. 50"Samuel Griswold Goodrich," 265.

${ }^{51}$ Goodrich, Recollections. See in particular $162-63$ and 23235. While Goodrich waxes enthusiastic about his principles 
and orientation toward the development of the youthful moral faculty, he coincidentally provides a stirring narrative of commercial savvy when he details his decision to publish juvenile non-fiction and early failures. Following his discussion of his initial non-fiction publications, he also provides a detailed account of copyright battles. In short, his celebration of his own success in such a chancy undertaking in the $1820 \mathrm{~s}$ and his defense of his market position puts him more clearly in the camp of the entrepreneurs that Lawrence Buell discusses than in that of the crusaders for edifying literature with his publishing and authorial projects. See Buell, New England Literary Culture, 60.

${ }^{52}$ Benedict Anderson. Imagined Communities: Reflections on the Origin and Spread of Nationalism (New York: Verso Books, 1991).

${ }^{53}$ David Waldstreicher. In the Midst of Perpetual Fetes: The Making of American Nationalism (Chapel Hill: University of North Carolina for the Omohundro Institute of Early American History and Culture, 1997), 109. Benedict Anderson briefly mentions that role that schools play in inculcating nationalism, see: Anderson, Imagined Communities, 113. For a discussion of how this political print culture could breed not public participation but instead merely an "imaginary" public life, see also: Michael Warner. Letters of the Republic: Publication and the Public Sphere in EighteenthCentury America (Cambridge, Mass: Harvard University Press, 1992).

54 The discussion in this section is informed by my reading of: Richard Helgerson, Forms of Nationhood: The Elizabethan Writing of England (Chicago: University of Chicago Press, 1992) detailing the Elizabethan cultural project of defining "a kingdom of our own language" which came to constitute "their own identity and consciousness" through literature, cartography and other ways of defining what England was and what was English. Quotation pg.3; and see especially Chapter Three. For contemporary discussions, see the prefatory notes in Jedidiah Morse's various geographies such as: Geography Made Easy, the first geography written and published by an American. And Morse's copious correspondence housed at Sterling Iibrary, Yale University which also details this attitude not only on the part of Morse, but also among his many correspondents, who ranged from Philadelphia merchants 
to a surveyor in New York state to historian Jeremy Belknap. See especially in Morse Family Papers: Jedidiah Morse to Jeremy Belknap, 18 January 1788; and, William Poole to Jedidiah Morse, 21 September 1792, Morse Family Papers, Special Collections, Sterling Memorial Library, Yale University. Helgerson, Nationhood, 3.

${ }^{55}$ Elson, Guardians of Tradition, 340.

56 For examples of this in introductory passages, see: Hannah Adams. An Abridged History of New England (Boston: Gray, 1807), 3; and, Charles A. Goodrich (Rev.). A History of the United States of America, on a PIan Adapted to the Capacity of Youths. $35^{\text {th }}$ edition (Boston: Richardson, Iord, and Holbrook, 1832), 3. In regard to this method of assembly, see Elson, Guardians, 10.

57 Benson Lossing, A Grammar-School History of the United States: From the Discovery of America to the Present Time (New York: Sheldon and Company, 1869.

${ }^{58}$ Thomas Hutchinson. The History of Massachusetts: From the First Settlement thereof in 1628, until the year 1750 . Vol.2. (Boston: Manning and Loring for Thomas and Andrews, no. 45 Newbury-Street, 1795), 62.

${ }^{59}$ Rufus Adams. The Young Gentleman and Lady's Explanatory Monitor. $2^{\text {nd }}$ ed., revised and corrected. (Zanesville, ohio: David Chambers, 1815), 152. These lessons came mainly through the Readers and all bear a striking resemblance to the denouement in the Salem witchcraft stories. For Readerbased lessons in vice and virtue, see especially: The Fourth Class Book: Containing lessons in Reading, for the Younger Classes in Schools. $2^{\text {nd }}$ edit. (Brookfield, Mass.: E. \& G. Merriam, 1828); David B. Tower and Cornelius Walker, North American Second Class Reader (Boston: Benjamin B. Mussey \& Co., 1849); and, F.W.P. Greenwood and G.B. Emerson, The Classical Reader: A Selection of Lessons in Prose and Verse. From the most Esteemed English and American Writers. Intended for the use of the Higher Classes in Publick and Private Seminaries. (Boston: Iincoln and Edmands, 1826). ${ }^{60}$ Elson, Guardians of Tradition, 213-15.

${ }^{61}$ Salma Hale. History of the United States from their first settlement as colonies to the close of the war with Great Britain. (New York: Charles Wiley, 1825); 44. ${ }^{62}$ Hutchinson. History of Massachusetts, 29. Books that draw 
upon Hutchinson very closely include: William Grimshaw. History of the United States (Philadelphia: Grigg and Elliott, 1832), 62; or Adams, Abridged, 160.

${ }^{63}$ Hutchinson, History of Massachusetts, 19. ${ }^{64}$ Ibid., 60.

${ }^{65}$ Colacurcio, Province of Piety, 207. See also: Goldberg, "School Histories," 176-179. Among those who adopted the Bancroft version of Salem witchcraft in the 1840 s editions of their histories were Emma Willard, Marcius Willison, Samuel Goodrich, Charles Goodrich, John Frost and Salma Hale's History, which was posthumously revised.

66 George Bancroft. History of the United States, from the Discovery of the American Continent. Vol.3 (Boston: Charles C. Little and James Brown, 1844), 86.

67 Ibid., 86-87.

68 Ibid., 87.

69 Ibid., 90.

70 Ibid., 95.

71 Ibid., 96.

72 Ibid., 98.

${ }^{73}$ Charles Carpenter. History of American Schoolbooks (Philadelphia: University of Pennsylvania, 1963), 201. ${ }^{74}$ Ibid.

${ }^{75}$ Emma Willard. History of the United States, or the Republic of America (New York: White, Gallagher, and White, 1828), vi. Most prefaces carried a similar message, for a sampling of similar ideas, see also: S. Goodrich, Peter Parley's History; S. Goodrich, Lights and Shadows; and, William Grimshaw, History of the United States (Philadelphia: J. Howe, 1824).

${ }^{76}$ Noah Webster. An American Selection of lessons in reading and speaking...also to instruct them in the geography, history, and politics of the United States. $3^{\text {rd }}$ ed. (Philadelphia, 1787), 5-6.

${ }^{77}$ A list of Popular Elementary School Books. (Boston: Carter, Hendee, and Co printed by Tuttle and Weeks, 1832), n.p. following page 21 in the catalogue. 
78"Review of Tales of Peter Parley About America, 2 ${ }^{\text {nd }}$ ed. American Annals of Education, 4 (March-April 1829), 191. ${ }^{79}$ Ibid.

${ }^{80}$ Goodrich, Recollections, 253. Goodrich's modesty about his fame is somewhat undermined in this account by the many pages recounting his reception and the details of those "soothing flatteries" about his many books.

${ }^{81}$ Goodrich, A History, 3.

${ }^{82} \mathrm{H}$. Adams, An Abridgment, 104.

${ }^{83}$ Frances Lister Hawks, Uncle Philip, 210.

${ }^{84} \mathrm{John}$ Howard Hinton, The History and Topography of the United States of North America, Brought Down from the Earliest Period. $2^{\text {nd }}$ edit. (Boston: Samuel Walker, 1843), 71. Hinton also cautions the children that although "the present age may censure the past" that they, in essence, did not understand their error. Ibid.,71n

${ }^{85}$ Olney, History, 44.

${ }^{86}$ Samuel G. Goodrich. The First Book of History for Children and Youth (Boston: Richardson, Lord and Holbrook, 1831), 28.

${ }^{87}$ Ibid. For a sampling of similar comparisons, see: Adams, Abridgment; Morse, American Geography, 165; S. Goodrich, First Book, 37; and Grimshaw ,History, 57.

${ }^{88}$ Samuel G. Goodrich. The First Book of History for Children and Youth (Boston: G.W. Palmer and Company, 1838), 36-7. ${ }^{89}$ Charles A. Goodrich. A History of the United States of America, accompanied by a book of questions and supplement by Reverend Joseph Emerson $35^{\text {th }}$ edition (Boston: Richardson, Lord and Holbrook, 1829), 67.

${ }^{90} \mathrm{~J}$. Olney. A History of the United States for the use of Schools and Academies (New Haven: Durrie and Peck, 1851), 67.

${ }^{91}$ Abiel Holmes, The Annals of America, from the Discovery by Columbus in the Year 1492, to the Year 1826 (Cambridge, Mass.: Hilliard and Brown, 1829), 438.

${ }^{92}$ William Grimshaw, History of the United States (Philadelphia: J. Howe, 1824), 57.

${ }^{93}$ Quotes in order: Grimshaw, History, 57; C. Goodrich, 
History, 66; Webster, Institutes, 150; Olney, History, 70; Adams, Abridgment, 160; and, Hinton, History, 68. This language is present in all of the books examined, for similar examples, see especially: Morse, American Geography, 191; Berard, History, 36; Olney, New Plan, 69; and Hale, History, 45.

${ }^{94}$ Olney, History, 67.

${ }^{95} \mathrm{John}$ Howard Hinton. The History and Typography of the United States of North America, vol. 1, $2^{\text {nd }}$ ed. (Boston: Samuel Walker, 1843), 71. Others also find a sudden shaking off of true beliefs in their versions of seventeenth-century Salem, see especially: Holmes, Annals, 440; and, Willard, History, 12.

${ }^{96}$ William Grimshaw. History of the United States (Philadelphia: Grigg and Elliott, 1832), 63,

${ }^{97}$ Salma Hale. History of the United States from their first settlement as colonies, to the close of the war with Great Britain in 1815 (New York: Collins, Keese, and Co.,1839), 46-47. This is a common transition within accounts, for other examples see: Olney, History, 70; S. Goodrich, First Book, 37; Lambert Lilly, The History of New England. (Boston: William Hyde, 1831), 13I; and, Hawks, Uncle Philip's, 211.

${ }^{98}$ Frederick Butler. A Complete History of the United States of America (Hartford: Frederick Butler, 1821), v.

${ }^{99}$ Ibid., 193.

${ }^{100}$ [Charles Prentiss] A Citizen of Massachusetts. History of the United States of America (Keene, N.H.: John Prentiss, 1822), 47.

${ }^{101} \mathrm{C}$. Goodrich, History of the United States, 78.

${ }^{102}$ John Clark Ridpath, A Popular History of the United States of America, from the Aboriginal Times to the Present Day (Cincinnati: Jones Brothers and Co., C1885), 161. ${ }^{103}$ Jedidiah Morse. The American Geography (Elizabethtown, New Jersey, 1789), 192.

${ }^{104} \mathrm{H}$. Adams. An Abridgment, 105.

${ }^{105} \mathrm{~S}$. Goodrich, First Book, 37. See also: Olney, New Plan, 70; S. Goodrich, Peter Parley's Book, 139; Hale, History, 45; and, Joseph Worcester Emerson, Questions and Supplement to Goodrich's History of the United States (Boston: 
Richardson and Lord, 1829) 100.

${ }^{106}$ S. Goodrich, First History, 37.

${ }^{107}$ Hinton, The History and Typography, 71.

${ }^{108}$ Fenning, Speller, 157.

${ }^{109}$ For a complete discussion of this method and its origins see especially: Elson, Guardians, 8-11; Frances FitzGerald, America Revised: History Schoolbooks in the Twentieth

Century (New York: Vintage Books, 1980), 18-19; John Nietz, Old Schoolbooks, 234; Charles Carpenter, History of

American Schoolbooks (Philadelphia: University of Pennsylvania, 1963); and, Daniel H. Calhoun. "Eyes for the Jacksonian World: William C. Woodbridge and Emma Willard" in The Journal of the Early Republic 4 (Spring 1984).

110 Quotes in order: Adams, Abridged, 183; Olney, A History, 69; Samuel G. Goodrich, A Pictorial History of the United States (Philadelphia: E.H. Butler \& Co., 1865), 101; and, A.B. Berard, School History of the United States. Revised edition. (Philadelphia: Cowperthwait and Company, 1867), 34. See also: Emerson, Questions, 100.

111 Hawthorne's biographer reports that Ticknor and Fields' prediction that House of Seven Gables would benefit from the popularity of The Scarlet Letter came true. Four separate printings went to press between April and September of 1851 for "a total of 6710 copies---710 more than the Scarlet Letter making it Hawthorne's best-seller. Critics were somewhat less enthusiastic but, nevertheless, found much to praise. See discussion of sales in: More, Nathaniel Hawthorne, 367-68. It was not, however, a national bestseller in the sense that T.S. Arthur's Ten Nights on a Barroom Floor was in the same period. On the 1850 s canonical works and sales, see: Tompkins, Sensational Designs, 199. 
CHAPTER TWO

NOT TO HEIL BUT TO SAIEM

In November of 1834, the New England Magazine included in its "Comments on the Times" an account of a sensational New York City trial then underway. The charges were embezzlement, fraud, and murder; the defendant a man who styled himself "the Prophet Matthias."1 Matthias, before becoming the self-described "Spirit of the Truth," was carpenter Robert Matthews from the Hudson River Valley region of New York. ${ }^{2}$ He had despotically ruled a small but devoted household of believers for two years. His story unfolded in newly competitive newspapers such as The Sun, a New York daily, during the fall of 1834. As the more scandalous details of life in Matthias" "kingdom" emerged, Americans were riveted by his story. The tale was propelled into national prominence by the combination of an alleged murder, rumors of sexual misconduct, and the bizarre doctrines and person of Matthias himself. ${ }^{3}$

Scandalous characters and public sensations like Matthias, who committed "uncleanness, seduction, and 
adultery.... in the name of the Lord," sold newspapers for the penny press. ${ }^{4}$ And as would true for the later controversy over the phenomenon of "spirit-rapping" in the $1840 \mathrm{~s}$ and 1850s, the New York Daily Tribune promised to "cheerfully publish all new facts."5 In covering the story of Matthias, reporters and editors scrambled to find new ways in which to describe his cult. The themes of scandal and seduction led them to Salem witchcraft, which through such references began its public career as a cultural metaphor during the 1830s.

The anonymous columnist in the New England Magazine, like most of the public, undoubtedly learned most of what he knew about Matthias' trial from newspapers. The details of the case and the language are similar between the two sources. 6 More strikingly, the judgments made about Matthias, his religion and followers in virtually all the print sources of the period bear a close resemblance to the imaginary and pedagogical literature about salem witchcraft. In fact, they and the New England Magazine provide an early map of the themes and language that would become familiar in nineteenth-century cultural debates as Salem made its appearance as an illustrative metaphor. Just as the fiction reader would find a comforting familiarity 
when Salem appeared as a plot device, so the reader of controversial literature through the nineteenth century would recognize allusions to witchcraft in public commentary on vice and virtue. Within the public debates related to religious controversies, the metaphor of Salem witchcraft emerged from the histories, schoolbooks, and fictional accounts and passed into broader circulation in ante-bellum America.

The citizen wondering about the Prophet Matthias, or any of the many other religious figures who arrived on the public scene during the century, would have well understood the terms "fanaticism," "delusion," "infatuation," "credulity," "impostors," and "superstition" when they were used in newspapers, books, and pamphlets to describe religious movements and their leaders. And those terms would undoubtedly have resonated (at least in the subconscious) with childhood lessons about Salem witchcraft. ${ }^{7}$ Salem witchcraft became a dramatic illustration that allowed writers, reporters, editors, polemicists, and even average citizens writing to newspapers to present their own arguments with the authority of historical precedent. History, after all, as their implicit arguments ran, shows us where such folly 
originates and where it is likely to lead.

Thus the 1834 New England Magazine column on Matthias labeled him an "imposter" and scorned his middle-class evangelical-minded followers as men whose "credulity and confidence knew no bounds. "8 ${ }^{8}$ But worse than the personal failings or crimes of these men were the broader implications of their misdeeds for the larger society. As another magazine noted, Matthias' believers were, after all, only partially culpable as "nothing but insanity accounts for the hideous delusion. ${ }^{\prime 9}$ What was more worrisome, the New England Magazine's writer insisted, was the "proof" such an affair offered "that human nature will ever continue what it always has been, in spite of the march of mind, and the spirit of improvement."10 In fact, the whole episode provided a revealing commentary on the times for the invention of religions such as Matthias' scorned the pretensions of an intellectual age. Human nature remained impervious to improvement, the Magazine suggested, when delusions hardly less absurd than in the time of witchcraft were current everywhere. ${ }^{11}$ Although the anonymous author did not specify Salem or a New Englandbased witchcraft episode, the eponymous magazine and the language used in the passage hint at it. 
Other critics explicitly used Salem as an illustrative metaphor in their commentary on Matthias and subsequent religious controversies. In 1835, William I. Stone, who wrote extensively on Matthias and his followers, charged Matthias with heading a religion whose very essence was a "series of delusions originating in fanaticism."12 It was Stone, in fact, who appears to have explicitly introduced the theme of Salem witchcraft into the Matthias controversy. Referring to strong religious beliefs that drove men to particular and disturbing actions, Stone reminded his reader of the model of the Puritans' "persecutions for witchcraft in the early days of New England." The Prophet Matthias' followers, like those early New England men, may "have been impelled by a strong but mistaken view of duty." ${ }^{13}$ Stone not only wrote a book (Matthias and His Imposture's[sic]) about the scandal, but also reported on the trial for the New York daily, the Commercial Advertiser. Three years later, in 1838, he also published a novel using the Salem trials as a subject. In the novel, Mercy Desborough, Stone apparently named the main character after Matthias' follower Anne Disbrow Folger's maiden name. Stone, childhood friend of Anne's husband Benjamin Folger, was completely sympathetic to the 
Folgers in all of his published writing. ${ }^{14}$ writers such as Stone suggested that Salem witchcraft exemplified a foreign, superstitious past that Americans had grown beyond with independence. In this he expressed more optimism than the essayist from New England Magazine.

As witch-hunting in seventeenth-century New England was itself inextricably bound up with religious controversy, it provided an especially apt metaphor for early nineteenth-century critics of radical religious sects. And of these there were many, for religious innovators rose and fell during the first half of the nineteenth century in a marketplace of spiritual ideas that was as vigorous as the burgeoning economic marketplace of the day. ${ }^{15}$ A number of religious groups and movements emerged in America, or spread from Europe, in fits and starts from 1790 until the 1850s. The Swedenborgians, established in major American cities by 1800, and the Spiritualists in the 1850s, offered adherents direct communication with dead loved ones or with God. Animal Magnetism or Mesmerism became popular among Americans in the 1830 s and 1840 s and promised to bring peace to the mentally ill by "aligning their individual forces with universal ones." William Miller prepared believers for the 
coming of Christ and the end of the world--several times-- in the 1840s. Joseph Smith revealed the Church of Jesus Christ of Latter Day Saints, or Mormonism, which reintroduced direct revelation from God to the world in 1831. A variety of other religious entrepreneurs likewise emerged in the $1830 \mathrm{~s}$ and $1840 \mathrm{~s} .{ }^{16}$

The rituals, hierarchies, and beliefs of these movements were alarming to the majority of mainstream Protestants. And a fierce debate arose about their place in the American religious tradition. Historian Jon Butler has asserted that the "vivid outburst of popular spiritual syncretism" of the post-Revolutionary era made the United States an "Antebellum Spiritual Hothouse." Although he was referring to the conditions for the growth of new religious innovations, he might as well have been referring to heated controversies that grew up with each "radical challenge to...religious, sexual, and economic values" that the new religions represented. ${ }^{17}$ The ensuing debate about the validity of the emerging religious sects raised pointed questions about what constituted legitimate and desirable religious practices in the new United States. As David Brion Davis argues, these often took the form of fears of "internal subversion" of American society and its cultural 
values. As such, the language of opponents to

religious innovation blended a claim to the preservation of American traditions of toleration with "faith in future progress."18

Indeed, nineteenth century opponents of the new religions even suggested that Mormonism could become "American" if it shed the practice of polygamy, the patriarchal church-community structure, and the doctrines that were inconsistent with Republicanism. Therefore, the true issue was one of cultural boundaries. In this context, Salem witchcraft gained power as a cultural metaphor for it neatly expressed fears that new religious sects were coming perilously close to the acceptable limits of religious expression. Some were indulging in practices that were implicitly dangerous to those involved and poisonous to the culture as a whole. In the case of Spiritualism, the danger was a retreat into an age of superstition from one of science and reason, while Mormonism not only imperiled rationality, but also threatened to introduce political innovations. Thus, the metaphor of Salem witchcraft expressed a desire for limits in American religious practice and warned against the dangers of transgressing traditional values. 
Positive religious models were, of course, consciously created in oratory, iconography, commemorations, and in every kind of print source. Schoolbooks functioned as particular repositories of "national truths" that provided a crucial inoculation in childhood against dangerous heresies, thus serving as "guardians of tradition."19 School geographies, histories, and readers had, by the late 1830s, already established a cluster of American virtues that were centered around the idea of a rational and progressive people. ${ }^{20}$ As primers for moral training, antebellum school histories emphasized that the United States was a moderate Protestant nation with a divinely appointed destiny. ${ }^{21}$ Part of the strength of the nation, the child was instructed, was that it was neither tyrannized by the Pope nor prey to "false religions."22

Roman Catholicism, on the other hand, was described in didactic literature in ways that critics would later find useful in anti-Mormon polemics. Like eastern religions which "departed most from the pure faith and worship of the one true God," ${ }^{23}$ its practices were fundamentally inimical to the development of the individual, his prosperity, his reason, and, especially, his freedom. The Inquisition appeared in several texts in colorful detail as evidence of 
the depravity of Catholicism. Pictures of "unhappy victims...strangled or committed to the flames" were instructional as "nothing ever displayed so fully to the eyes of mankind the spirit and temper of the papal religion." ${ }^{24}$ Such systems of belief reflected the level of "civilization" in a nation, with American Protestantism representing the highest end of the spectrum. With the world clearly divided into religions that were "true" (Protestant) and "false" ("Hindoos" and Catholics in particular), the child was provided with a standard by which to assess people's spiritual condition.

The issue of "toleration," a perennial schoolbook virtue, at least in the abstract, proved especially important to debate about emerging religious and quasireligious movements in nineteenth-century American society. Mitchell's Geography informed children that while "every man may worship God according to the dictates of his own conscience," only "Christianity" provided the proper "basis of the government and institutions."25 Toleration, however, as described in antebellum culture in general, did not mean allowing license to any popular religious or political notion. Finding the "truth" was not promoted by "Iistening to error and falsehood." For the American people needed to 
know the "criterion by which we may determine with certainty, who are right, and who are wrong."26

The idea of a "right" and "wrong" religion fueled relentless invective in nineteenth-century religious controversies. Critics of new religions focused on swaying public opinion by defining spiritual innovations as not "religions" at all. In this context, Americans were a tolerant people because they accepted those who exercised their freedom of religion in appropriate ways. But the religious, social, and even political movements that were considered "religious delusions" in the nineteenth century were many. Certain factors in faith systems especially caused them to be categorized as dangerous. In print genres ranging from periodicals and sermons to monographs, speeches, and editorials, critics challenged religious innovators who undermined "American" values. Persistent lines of attack included questioning the degree to which the faithful had lost their reason because of their involvement in the religious sect. ${ }^{27}$ Were the structure and doctrines of the religion "foreign" to a republican people ${ }^{28}$ And, most especially, did specific individual religious practices have a deleterious effect on the broader society? From the 1830 s through the end of the 
century, Salem witchcraft provided an effective point of reference for those who struggled with these questions.

This dynamic was especially evident in the debate over one of the nineteenth century's more unorthodox belief systems. Little more than a decade after the Prophet Matthias scandal highlighted some of the more disturbing potential in the various religious revivals and social movements sweeping America, reports of strange phenomena in upstate New York introduced the nation to Spiritualism. Twelve-year-old Kate and fourteen-year-old Margaret Fox of Hydesville, New York came to the attention of the general public in 1849 reports of their "rapping" communication with the "spirit world." 29 Critics would immediately focus on the geographical center of spiritualist activity. For the location was also the site of Mormonism's and Millerism's origins - a place "famous for queer things."30 Likewise, Essex County, Massachusetts, as one newspaper noted, was "a credulous place." Indeed, it qualified as the "grand seat of supernatural wonders" as the alleged home of a large number of local Spiritualists, as well as the starting point of "Salem witchcraft and Mormon founder Smith."31 In fact, during the sectional crisis, Southern 
writers seized on the purported New England origins of Spiritualism, Mormonism, and other utopian religions in their criticisms of Northern fanatics. The South, Jeffrey A. claimed, in the Southern Literary Messenger, was removed from such wild extremism as could be found in New England. "We know little of its freaks from the days of witchdrowning...the rise and fall of Millerism, the growth of Mormonism or Puritanical Mahomedanism [sic] ... Spiritualism, [or] Free Loveism." "Why is it," the author asked, "that no other land in the world has troubled mankind with such terrible abominations?"r32

Spiritualism took hold of the national imagination when, in 1850, the Fox sisters had left Hydesville for New York City. With their much older married sister Leah Fox Fish, they demonstrated their "rapping" and their ability to channel spoken messages from the dead for selected individuals and before sell-out crowds. ${ }^{33}$ Spiritualism appealed to such a broad cross section of seekers, that some Americans in the 1850 s and 1860 s thought that to dismiss it immediately with only "a shrug and a sneer" was foolish. ${ }^{34}$ The bereaved were promised another chance to reach departed loved ones. Those seeking everything from Christian perfectionism to medical treatments and 
scientific proof of life beyond death gravitated toward Spiritualist demonstrations and séances. ${ }^{35}$

Spiritualism would have another benefit that attracted long-term adherents as well as dilettantes. It, like William Miller's movement foretelling the end of the world in the 1840s, could be adopted alongside one's primary religious affiliation. ${ }^{36}$ In fact, Spiritualism, like Millerism, had no institutional foundation and no set dogma. As a movement more than a religion, it offered "extreme individualism" in practice and belief. ${ }^{37}$ Historians have, however, disagreed about the source of Spiritualism's appeal to mid-nineteenth-century Americans. Ann Braude finds diverse reasons that range from grief reactions to entertainment to rebellion against both authority and mortality. ${ }^{38}$ Jon Butler emphasizes that Spiritualism served to "satisfy" the search for "supernatural medical regimens" and the interest in millennialism. ${ }^{39}$ David Chapin sees the interest in Spiritualism as part of a "culture of curiosity" that pervaded antebellum America. ${ }^{40}$ Other scholars, such as Brett Carroll, see a search for order in a world undergoing rapid change. Rather than constituting rebellion, Carroll views the Spiritualist claim to communicating with the dead as an effort to reclaim the 
past and restore "disappearing sources of authority and security." 41

Regardless of whether Spiritualism reflected social or status anxieties in its believers, the movement certainly revealed the anxieties of critics. Jon Butler stresses that Spiritualism was considered part of a Protestant-based faith system prior to 1870 , in part because ministers regularly inveighed against it, demonstrating that it was seen as drawing converts from their flocks. ${ }^{42}$ Soon after the Fox sisters arrived in New York City in 1850, ridicule began in earnest, and it came from all quarters. A letter to the editor of the New York Tribune complained that the paper was insufficiently skeptical of the Eox sisters, whose claims hinted of the "absurdities of modern witchcraft." 43 Although most new religious movements at one time or another drew charges of "fanaticism" or "delusion," to express disapproval with the backwardness or "superstitious" nature of their practices, Spiritualism, and quasi-religious practices such as Mesmerism and Clairvoyance came under particularly harsh attack. Their adherents were regularly labeled as fanatics and charged with leading the rest of the nation away from reason and light and toward the dark ages. 
Before critics settled down in earnest to elaborate their view of Spiritualism as the latest of "one popular delusion [that] runs into another,"44 there was a brief "honeymoon" when some skeptics were willing to wait for proof of truth or fraud. The Democratic Review urged in 1847 that "reason" and "evidence" be used to evaluate the claims of Mesmer and Swedenborg. Is it reasonable to simply "ally it in public estimation with witchcraft" before all the facts are known, its writer.asked? ${ }^{45}$ There was a certain degree of curiosity and open-mindedness about Spiritualist mediums in the 1850s, who were sometimes credited with increasing scientific knowledge. ${ }^{46}$ Spiritualists, in fact, often "borrowed from American's burgeoning scientific language," according to Jon Butler, and "observers at séances heard as much about scientific 'laws' as about revelations." 47 A correspondent to the Southern Literary Messenger in 1850 advised just such a "wait and see" attitude toward spirit communication and provided a rare example of Salem used in support of Spiritualism as a potentially progressive idea. He sternly criticized the occasional "savage customer" who verbally abused the Fox sisters. Such rudeness demonstrated to his satisfaction that, despite the "boasted light of the nineteenth 
century," the spirit of inquiry was often aced by "the spirit which hung the witches." 48

Progress remained a chief concern for those who assessed Spiritualism. The days of Salem witchcraft brought to mind men who, "creeping cautiously along the narrow limits of the known," could not clearly distinguish between either fraud or delusion. ${ }^{49}$ So too William Hammond observed in an 1870 essay for the North American Review, only "two classes of individuals have been concerned in the propagation of false ideas relative to the phenomena... [of]the agency of spirits. These are the deceivers and the deceived." to call...witchcraft and necromancy" were being "shielded under the respectable mantle of science" tormented commentators who listened to the claims of the Spiritualists. ${ }^{51}$

Reports of communication with deceased notable persons designed to show the benefits of Spiritualism sometimes backfired to the delight of skeptics. An 1853 report of one medium's contact with the late Senator John C. Calhoun in the New York Daily Times drew an angry letter. The reader refused to believe that Calhoun would "condescend to return to earth in order to crawl under a 
table" and make rapping noises. Since this was not something the dignified Calhoun would have done in life, "can it be supposed that he has become a mountebank since his death?"52 Such hostile responses often included claims that anyone who believed in the reported afterlife antics of dignified and well-known individuals was suffering from the sort of "delusion... which has not been much in favor since Cotton Mather's days when it led to deplorable consequences."53 Spiritualist claims of contacting Iuminaries in death led a Massachusetts orator to jest in 1850 about the resemblance between such outlandish assertions and witchcraft. The speaker ventured that, were he to believe that he could "get up a conversation with General Washington about fly traps, or with John Adams on the respective merits of hair-dyes... I intend to believe also, unreservediy in the Salem witchcraft!"54

Indeed, Spiritualism acquired in short order not only a devoted following but ardent critics who indicated that there was a fine line (or perhaps none) between fanaticism and insanity. Some physicians chose to explain both the intensity and the stubbornness of spiritual belief by medicalizing religious fervor. ${ }^{55}$ In 1838 , in the wake of Matthias and amid the advent of Mormon activity in New York 
City, physician David Meredith Reese had devoted a volume to that "species of infuriated insanity called fanaticism."56 The idea gained great currency in a society where Protestant revivals and new religions were gaining enthusiastic converts daily. By 1850, the connection between fanaticism and mental illness was so thoroughly established that the New York Herald, looking north to Rochester demonstrations of "spirit-rapping," called the practice the sort of behavior that "commands so much respect in the Iunatic asylums throughout the country."57 Such enthusiasms ran the danger, it was generally feared, of spreading and becoming "an epidemic delusion, like the delusions which have prevailed in past times in regard to magic [and] witchcraft."58 When laymen countered with the argument that the wide-spread popularity of Spiritualism was "proof" that it was not a product of delusion, physician George M. Beard asked whether popularity of an idea was proof of its validity. In that case, what was the use of science? We should then base our judgments on referendum. That would make our intellectual shrines "the birthplace of mesmerism and mind-reading, the Witches' Hill at Salem, the house where spirit-rappings first appeared" and other similar locations. ${ }^{59}$ 
Some who rejected explanations of Spiritualism inflected with medical overtones preferred to see the movement as a "careering sweep of popular excitement." They likened it to "a phenomena [sic] of the present day [that] does not surpass those witnessed during the salem witchcraft."60 Others saw the parallel in credulity backed by force as in "Salem witchcraft [which] was a sheer delusion, fostered by imposition."61 A writer for the New Englander and Yale Review in 1860 suggested that Spiritualism could be explained if readers considered that every era used its own "power of the imagination to invest the supernatural with a seeming presence and to associate the supernatural with unexplained phenomena. "62 What was now being attributed to "the agency of spirits," two hundred years ago was "in vogue among the witches of Salem."63 Delusions and fanaticism were not mere intellectual curiosities, critics of Spiritualism and other religious enthusiasms stressed. Rather, they constituted a danger to American material and moral progress, as every schoolchild knew. "Minds not sufficiently enlightened by reason and philosophy," Hannah Adams warned in 1806, could hardly be expected to contribute to the nation's intellectual, economic, or moral progress. ${ }^{64}$ What each age expected when 
under the influence of delusion was not improved by the reportedly benign nature of the current spirit beliefs. Proof of this argument, one writer suggested, could be easily enough found. "It will be sufficient to refer to the Salem witchcraft... which is easily explained if we [consider that it was] an age which was prepared to expect visitations from infernal rather than from celestial spirits."65 In fact, this writer predicted that one day Spiritualism would be viewed "with the vague skepticism with which most persons regard the diabolical workings" found in Salem in 1692. ${ }^{66}$ Readers of articles on religious innovation were likewise reminded that "we profess to look down with lofty pity upon the benighted ignorance that persecuted those who were accused of witchcraft." But, one essayist concluded, if we but glance about us "we have our innumerable forms of spiritual fanaticism." 67

Spiritualism commonly gave rise to charges of fraud, particularly after the Civil war. Here too the specter of Salem appeared in nineteenth century meditations on new religious enthusiasms. Investigators probing into Spiritualist gatherings revealed the tricks some mediums used to produce rapping or other "manifestations" for their clients. The very presence of "counterfeit clairvoyants 
[and] shamming mesmerizers" proved that everything from Mesmerism to Spiritualism was "knavish or selfdeluded," claimed Putnam's Magazine. ${ }^{68}$ What caused people to advance such deception? One observer suggested simply "love of notoriety, hope of gain, the prosecution of some private intrigue" or other unknown personal motivations. ${ }^{69}$ This writer recalled Salem when he read the descriptions of physical possession reported in histories of other "familiar examples of wide-spread contagious delusions."70 Thus, practitioners of the "arts or sciences" of Mesmerism, clairvoyance, and Spiritualism were "pretenders," but their clients suffered from "self-delusion."71 George Fitzhugh, reviewing a series of books on metaphysics for Debow's Review in 1867, echoed such criticism. He noted that both "phrenology and mesmerism...are blemishes" on American claims to living in a rational and scientific age. He charged both with being "pretended sciences." "Witchcraft, two centuries since, was much better attested and more generally credited,"72 than phrenology or mesmerism, Fitzhugh observed. And yet, "the philosopher who should embrace witchcraft within his program of facts, arts or sciences, would forfeit or at least impair his reputation." 73 
As harsh as these attacks on Spiritualism and other nineteenth-century religious innovations often were, they were temperate in comparison to the attacks on Mormonism before and after the Civil War. Deluded or fanatical believers who claimed to have contacted Benjamin Franklin or a lost child distressed the advocates of reason. Mormonism, on the other hand, threatened not just the belief in rationality and progress, but fundamental democratic values. Mormonism was full of practices out of place in a republican society, or so its critics insisted. It followed a strong central leader, and in its early decades advocated magic and occult practices, aggressively proselytized, and called for a "kingdom" that was, at the very least, only ambiguously located in Heaven rather than on earth. ${ }^{74}$ Thus, with teachings "subversive of freedom, morality, and progress," Mormonism, in the eyes of its opponents, threatened the entire political order. ${ }^{75}$

A Revolutionary-era prayer was invoked in an 1835 North American Review article to predict the fate of the followers of the Church of Jesus Christ of Latter Day Saints. Followers of Joseph Smith and his church, it insisted, would have to "be brought to reason or ruin."76 This could have served as a motto for the forces that 
allied to condemn Mormonism from the 1830 s through the early twentieth century. Many believed that the task of discrediting Mormonism was nearly impossible. For some retained sympathy for the travails of the Mormons as they sought a home and insisted on their right to worship freely. The Rochester New York newspaper The North Star published by abolitionist and escaped slave Frederick Douglass, asserted that "witchburnings [sic]...afford the only adequate parallels" to the persecution of the Mormons. ${ }^{77}$ But such views were rare after the anti-Mormon forces started printing diatribes against the religion in earnest in the 1840s. E.D. Howe, an Ohio editor and persistent foe of the Mormons, saw no reason at all for sympathy. In Howe's opinion, the Mormons were not part of a religion but rather fanatical devotees of a single sinister man. And, Howe insisted, they were an excellent example of the fact that, once entrapped "there is no turning a fanatic from his folly."78

Nowhere in the discussion of religious enthusiasm was the metaphor of Salem more rife than in critical commentary on Mormonism in the nineteenth century. The history of the Chirch of Jesus Christ of Latter Day Saints, most commonly known as Mormons, began when New York resident Joseph Smith 
announced in 1830 that God had revealed golden plates to him which contained the Book of Mormon. ${ }^{79}$ Smith organized his church in Fayette, New York in 1831 and actively sought converts. Smith and his followers would travel from New York to Ohio, Missouri, Illinois, and Iowa before finally establishing their patriarchal kingdom in Utah territory in 1847 . They would reach the promised land without Smith, however, as he was murdered in Carthage, Illinois by a mob in 1844. Unlike religious movements such as Spiritualism or Millerism, the Mormons developed an institutional structure, complex ritual, and elaborate doctrines. These factors plus the fact that the Mormons endured eviction, mob violence, murder, and persistent attacks in their efforts to form a faith community helped to establish the religion as a major worldwide church in the twentieth century. The Latter Day Saints had a longterm history of attacks by opponents, they were often criticized in the same terms as other nineteenth century sects. In fact, the anti-Mormon literature is striking for its sameness over seventy years. Iong after Millerism and Spiritualism were gone from the cultural scene, anti-Mormon literature was still recycling not only arguments but also the language in which they were framed during the 1840s. 
Various features of Mormonism precipitated particularly virulent opposition among the church's American critics. The image of Salem well served these antagonists.

In the eyes of opponents, to become and remain a Mormon was, as for membership in other rising sects in the nineteenth century, a sign that one was mentally ill or unstable. In an autobiography describing his conversion, Daniel Tyler recounted his older brother's attempt to steer him away from the Mormon religion at age 15. Tyler was told that "good people said it carried the spirit of witchcraft, which caused those that read it to be bewitched and join the 'Mormon' church." ${ }^{180}$ Converts in the 1850 s were assumed to be inherently susceptible to "excitements and loss of reason;" this propensity resulted in their becoming "contemptible slaves of a degrading superstition." ${ }^{81}$ Indeed, the level of fanaticism found in Mormonism, said one commentator in 1853, recalled the "days of witchdrowning." ${ }^{82}$ The current rise of Mormonism, claimed the New Englander and Yale Review in 1860, would one day be viewed as "the present generation looks upon the Salem witchcraft, as a miserable imposture and delusion." ${ }^{183}$ That is, the Philadelphia Christian Observer, a Presbyterian newspaper, 
raged, "if their religious apprehensions may be called faith." If so, then it is "more astounding than faith in witchcraft... which prevailed among many in the seventeenth century. ${ }^{84}$ If the Presbyterians in 1844 didn't know, or did not want to admit, where the blame lay for Joseph Smith's own "delusions and impostures," the Roman Catholics offered an analysis in 1877. Protestant revivals were at the root of Mormonism, the national Roman Catholic lay publication Catholic World insisted. For Smith's "writings abound with revival phraseology; his pretended revelations are full of the cant-terms of the campmeeting." 85

Charges of fanaticism or delusion in relation to Mormonism rarely focused on doctrinal or ritual practices that opponents found objectionable (with the exception of polygamy) but more often stressed the control that the church leaders had over the faithful and non-believing gentiles of Utah. In relation to this argument, as Kenneth Winn argues, geographic proximity was an important issue. The 1847 removal of the community to Utah territory gave opponents "proof" that the Saints intended to build an earthly kingdom with Church leaders in both spiritual and secular control reminiscent of Puritan rule. Called "a rude 
Cromwell" or "Pope Joseph the First," Joseph Smith, and later Brigham Young and the ruling council of the church, were harshly attacked for pursuing "patriarchal" or "kingly" authority in Utah after $1847 .^{86}$ Opponents charged Smith with attempting to "establish a new theocracy...to crush all individual will and freedom of thought" through his "pretended revelations."87 Smith's "priestly rule" and "patriarchal" authority hinted at popes in America, according to a North American Review article. The neighboring Atlantic Monthly had already defined the religious problem of the century as "tending more and more to the two poles, Rome and Reason."88 "That old New England divine" entered into this drama of tyranny in a republic as "chuckling over his conceit of certain poor women, who had been burned to death in his own town. "89 Just as that "divine" found his authority in the Bible, so too, critics asserted, did the Mormons or, the "vulgar," in our own midst base their authority. ${ }^{90}$

With a revolution to throw off monarchy and their later battles over disestablishment, Americans certainly had reason to be wary of tyranny in any form. Americans could follow practices that involved "seer stones" or attention to astrology or any number of unusual rituals 
that Mormonism and other religions in the nineteenth century could devise, even if neighbors sometimes looked askance. Because, in the end, such habits could be dismissed, or even slandered, as derangements that stemmed from an excess of piety. But that followers could submit to a church that required in sacred and secular matters "unquestioned and unquestioning obedience which is extracted from these people $e^{\prime 91}$ was a mystery that tormented opponents. Religions that required "obedience" were tyrannical, and tyranny hinted at kings and popes. Therefore such things were a public not a private concern. Readers of polemical literature on Mormonism, which was full of words such as "tyrant," "king," and even "patriarchy," could not fail to conclude that these concepts were alien or hostile to American society and government. What a late-century reader might also find, however, from the 1880 s onward was that newly written textbooks left "the distinct impression that religious freedom does not extend to Mormons." 92 Other books were very clear on the matter. Emma Willard's 1868 edition of her schoolroom history describes Mormonism as "the most extraordinary imposture of the age." The religion, Willard asserted, gave its followers "license to commit every crime 
which may be sanctioned by the leading prophet."93

Some felt that they had found their answer to how such a religion as alien as Mormonism not only rose up but also prospered. Knowledge of the Church's aggressive proselytizing efforts in Europe led critics to describe Mormons as "chiefly foreigners; and rude, ignorant foreigners they are." 94 Many, it was true, might be English, but they still belonged to "the foreign element [which] predominates in Utah." The Southern Literary Messenger claimed that "the tyranny of fanaticism" was originally imported from England with the Puritans. That migration to American shores alleviated England's religious strife in the seventeenth century, just as the exodus of Mormon converts to America in the nineteenth century promised to do again. ${ }^{96}$ The Mormon church, claimed one writer for Scribner's Magazine in 1879, might have begun in the United States, but it "has lost every trace of Americanism." C. C. Goodwin, in a 1881 essay for Harper's Monthly called Mormonism "so absolutely un-American in all its requirements, that it would die of its own infamies within twenty years except for the yearly infusion of fresh serf blood." 97 Debow's Review complained of the "heterogeneous combination of all climes and countries...[of] that 
Northern system...from the rigidity of Puritanism to the licentiousness of Mormonism."98 This transformation into a "foreign theocracy" was effected by encouraging immigration "from the peasantry of the Old World." 99

Combining ideas such as foreign origins, theocracies, and tyranny with Puritanism was effective. Every American schoolboy in the nineteenth century was well versed, in particular, in the evils of tyranny. In her study of schoolbooks, Ruth Elson notes that the training a child received in everything from spellers to histories taught that kings and popes were sources of evil for their subjects. ${ }^{100}$ Much of the coverage of Salem witchcraft in the school histories implied a similar parallelism between foreign autocracy and wickedness. Puritans who tried and hanged witches followed, after all, "the practice of the courts...regulated" by English "precedents."101 These immigrants, said an 1861 Samuel Barber United States history text of foreign-born Mormons, "have not the first conceptions of their duties to our government, or of their duties as American citizens. They come to Zion, but they do not come to America."102

But it was not only demographics that brought in charges of foreign influences. Polygamy presented both a 
moral and a political problem for the admission of Utah as a state. Polygamy, said opponents of Mormonism, was a product of "lusts and superstition."103 As Allan G. Campbell put it, "polygamy is only one of a series of evils, attracting attention by its prominence rather than its preeminence over its fellows."104 Whatever its significance, one thing was certain: the issue of polygamy could be used to stir up the public. In so doing, critics placed Mormonism outside the Christian tradition.

Polygamy thus offered the opportunity to portray Mormonism as both immoral and foreign. A "degradation" to both men and women, the practice was the "reward that Mohammed offered to men's lusts."105 On judgment day, two men would surely pay for their sins in life, said the Ladies Repository in 1859. "Mohammed shall suffer for the dupes of the Koran, Joe Smith for the Mormons."106 Indeed, Mormonism's unique crime was to draw upon the worst religious precedents in the American nation and mix them with foreign influence. By reviving religious patriarchal government in America and introducing polygamy, Mormonism has "mixed Puritanism with Mohammedanism." And, by Puritanism, this critic was careful to clarify, "we mean...the kind that burned witches."107 Still, territorial 
Representative W. H. Hooper found a use for Salem in his defense of polygamy. He appealed in this "age of great religious toleration" for allowing the religious practice of polygamy to remain legal. The anti-polygamy bill then before Congress, Hooper said, recalled "the fearful days... when in New England... witches burned at the stake."108

A fundamental fear pervaded debates about the new religious enthusiasms of nineteenth-century America, particularly Mormonism. Critics worried about the effect a religion's concentrated political power would have on the rest of the nation once it had established a majority population. Mormons themselves provided prophecies about world-wide conversion that alarmed Americans. In 1832, prominent Mormon Martin Harris publicly predicted:

every sectarian and religious denomination in the United States, shall be broken down and every Christian shall be gathered unto the Mormonites...the righteous will be gathered to Zion...there will be no president of the United States. ${ }^{109}$

Three years later, during their sojourn in Kirtland, Ohio, his prophecy appeared to be coming true. An all-Mormon slate for township offices so frightened Whigs and Democrats that they rushed "into each others arms" to narrowly defeat the "church ticket."110 when a 
Mormon ticket did prevail in 1836, the ensuing hysteria fueled Ohioan efforts to drive the Mormons out of the region lest something resembling a Puritan republic ruled by ministers rise again in their midst. In this context Brigham Young, who assumed leadership of the church upon the death of Joseph Smith, appeared to much of gentile America, it was claimed by Allan G. Campbell, as an "imperium in imperio' almost as dangerous... as the slave oligarchy of the South."111 This perception was undoubtedly reinforced by the concurrent use of the example of the Puritan theocracy's descent into witch-hunting in the sectional crisis(a subject addressed in the next chapter). Campbell also warned in 1859 that Mormon practices and the structures required to maintain them threatened to take the church "out of the sphere of religion and of necessity brings it into conflict with a republican people and their institutions." ${ }^{112}$ Political scientist Francis Lieber was equally firm on this point. It would be "insane," Lieber argued, "to admit a class of people, so entirely incongruous with us as the Mormons are...can we admit, as a state, a society of men who deny the very first principle... of our whole western civilization?"113 For if the Mormons prevailed, The 
Princeton Review argued during the 1859 campaign, the people of Utah territory would lose the "principle of individual liberty and responsibility... [that is] so strikingly characteristic of the American mind."114 The Century in 1882 was still warning that the Saints, left alone with their church-directed territorial government and their polygamous family arrangements, would cause Utah to "break at last in tears and blood, and drench the whole land." 115 When Utah statehood appeared about to come to a vote again in 1882, The Century warned against admitting "any people who are not capable of autonomy... [they] are only a weakness to us."116 By 1882, the sectional crisis rhetoric, the religious controversies, and even the Civil War would have impressed upon Americans the lesson of Salem witchcraft whose religious "delusions" and "fanatical" leaders unleashed mayhem on the Massachusetts countryside. When Americans looked to Utah with its central Church leadership and majority status in the electorate, it is not a far stretch to say they wondered whether the anti-Mormon writers who used the warning of Puritan Salem might not be right.

Perhaps it was true that "all the schoolmasters in the world"117 could not stave off the emotional upheavals that 
came with nineteenth century religious

"enthusiasms," as the 1835 New England Magazine writer exclaimed. But they could and did provide a cultural context and vocabulary for judging such new spiritual movements. Strangely enough, the violent rhetoric in opposition to such religions suggests that their neighbors believed followers of these sects were not as much at risk of going to hell as of going to Salem. As the sectional crisis deepened in the 1850s, Salem witchcraft would make a transition from a religious counter-example to a political metaphor that delineated the "fanatical" aims of the largely New England-based abolition movement. With that application, the cultural metaphor of Salem witchcraft would become truly national. 
Notes to Chapter Two

1 "Comments on the Times," New England Magazine, vol. 7, issue 5 (November 1834), 407-13. The Magazine misspelled his name calling him Robert "Matthies." Ibid., 408. For a full history of Robert Matthews and his "kingdom," see also: Paul E. Johnson and Sean Wilentz, The Kingdom of Matthias: A Story of Sex and Salvation in 19th Century America (New York: Oxford University Press, 1994, and, Thomas M. McDade, "Matthias, Prophet Without Honor," NewYork Historical Society Quarterly 62 (1977):311-34.

2 Johnson and Wilentz, Kingdom of Matthias, 145.

${ }^{3}$ For coverage of the trial in the New York press from Octcber 1834 through April 1835 in addition to The Sun, see especially: Evening Post; Commercial Advertiser; and NewYork Observer. For periodical coverage of the trials, see also: "Matthias and His Impostures," North American Review 89 (1835):307-27. Several pamphlets and books quickly appeared detailing the most scandalous aspects of belief and conduct which include: Memoirs of Matthias the Prophet, with a full exposure of his atrocious impositions, and of the degrading delusions of his followers (New York: The New York Sun Press,1835); [Margaret Matthews], Matthias. By His Wife (New York, 1835); G[ilbert] Vale, Fanaticism; Its Source and Influence. Illustrated by the Simple Narrative of Isabella, in the Case of Matthias, Mr. And Mrs. B. Folger, Mr. Pierson, Mr. Mills, Catherine, Isabella, \&c., \&c. 2 vols. (New York: , 1835); W.E. Drake, The Prophet! A Full and Accurate Report of the Judicial Proceedings in the Extraordinary and Highly Interesting Case of Matthews, alias Matthias (New York, 1834); and, William L. Stone, Matthias and His Impostures; or the Progress of Fanaticism. Illustrated in the Extraordinary Case of Robert Matthews, and Some of His Forerunners and Disciples (New York: The Sun Press, 1835).

${ }^{4}$ Vale, Fanaticism, 4. The anonymous pamphleteer who produced the "memoirs" of Matthias promised to write "with a due regard to public decency" but hinted at the activities in the communal house where followers were "engulfed" in "wild vortices of fanaticism." Memoirs, n.p. 
${ }^{5}$ New York Daily Tribune, December 5, 1849.

${ }^{6}$ For a discussion of the role that print culture and particularly daily newspapers (often also called the "penny press") played in sensational trials of the nineteenth century, see: Alexander Saxton, The Rise and Fall of the White Republic: Class Politics and Mass Culture in Nineteenth Century America (New York: Verso, 1988); and, Dan Schiller, Objectivity and the News: The Public and the Rise of Commercial Journalism (Philadelphia: University of Pennsylvania Press, 1988). In regard to specific trials one should start with the 1836 Helen Jewett murder for which the Matthias scandal acted as a dress-rehearsal: Patricia Cline Cohen, The Murder of Helen Jewett (New York: Vintage, 1998); for a discussion of the moral dimension of the narratives of murder, see: Karen Halttunen, "Early American Murder Narratives: The Birth of Horror," in Richard Wightman Fox and T.J. Jackson Lears, eds., The Power of Culture: Critical Essays in American History (Chicago: University of Chicago Press, 1993). Forty years after the Matthias trial brought sex, religion and newspapers together, the Beecher-Tilton scandal showed the maturation of the form, see: Richard Wightman Fox, Trials of Intimacy: Love and Loss in the Beecher-Tilton Scandal (Chicago: University of Chicago Press, 1999).

'Each of these words is ubiquitous in the school texts' presentation of Salem witchcraft. Authors of such books made judgments on the catalysts for the original episode. For "imposture," see especially: Salma Hale, History of the United States: From their First Settlement as Colonies, To the Close of the War with Great Britain (New York: Charles Wiley, 1825), 46-7 and Frances Iister Hawks, History of the United States I. Or, Uncle Philip's Conversations with the Children about Massachusetts (New York: Harper \& Brothers, 1835), 211. Hale was published in 1825 well before this term was applied to religious controversies like Matthias. Although Hawks, also known as "Lambert Lilly" and "Uncle Phillip" published his United States History in 1835, the same appears in his 1831 volume on New England, see: Lambert Lilly, The History of New England (Philadelphia: William Hyde, 1831. For a sampling of those which include at least one of the following: fanaticism, delusion, infatuation, hysteria, credulity, or superstition, see 
especially: Hannah Adams, An Abridgement of the History of New England. For the Use of Young Persons (Boston: B. and J. Homans and John West, 1805), 164; J[ohn] Olney, $A$ History of the United States for the use of Schools and Academies (New Haven: Durrie and Peck, 1851), 70; Abiel Holmes, The Annals of America, from the Discovery by Columbus in the Year 1492, to the Year 1826 (Cambridge, Mass.: Hilliard and Brown, 1829), 438; Samuel Goodrich, The First Book of History: For Children and Youth (Cincinnati: C.D. Bradford \& Co., 1832), 37; and, A [ugusta] B [lanche] Berard, School History of the United States (Philadelphia: H. Cowperthwait \& Co., 1855), 36. Given the nature of creating schoolbooks from compilation, it is impossible to tell which influence might be strongest upon the language of the 1830s and 1840s era new (versus the endless and unrevised post-1834) books. Although many of the books first published in the late-1830s might be including language drawn from the contemporary debates about "religious fanaticism," all of these terms had been associated with Salem witchcraft in histories well before 1834. For a discussion of the language used to describe Salem witchcraft, see Chapter One and Conclusion.

${ }^{8}$ New England Magazine, 409.

${ }^{9}$ North American Review, 324. (October 1835) 10

Ibid.

11 New England Magazine., 409. In addition, the words "infatuation," "delusion," "imposture," were used repeatedly in the review of Stone's book on the scandal by The North American Review 41, vol.89 (October 1835):307-27 passim.

12 Stone, Matthias and his Impostures, 321. ${ }^{13}$ Ibid., 16.

${ }^{14}$ On his friendship with and sympathy for the Folgers, see: Johnson and Wilentz, Kingdom of Matthias, 165-67. Although Johnson and Wilentz do not mention this link (or Stone's novel), they mention Ann Folger's maiden name in their discussion of her background. Ibid., 29. 
${ }^{15}$ Jon Butler, Awash in a Sea of Faith: Christianizing the American People (Cambridge, Mass.: Harvard University Press, 1990), 247.

16 On various antebellum religious movements under discussion in this chapter, see especially: Butler, Awash; Hatch, Democratization, Johnson, Shopkeeper's; David L. Rowe, Thunder and Trumpets: Millerites and Dissenting Religion in Upstate New York, 1800-1850 (Chico,Calif.); Richard L. Bushman, Joseph Smith and the Beginnings of Mormonism (Urbana: University of Illinois Press, 1985); Kenneth H. Winn, Exiles in a Land of Liberty: Mormons in America (Chapel Hill: University of North Carolina Press, 1989): Jan Shipps, Mormonism: The Story of a New Religious Tradition (Urbana: University of Illinois Press, 1985); Terryl L. Givens, The Viper on the Hearth: Mormons, Myths, and the Construction of Heresy (New York: Oxford University Press, 1997); D. Michael Quinn, Early Mormonism and the Magic World View (Salt Lake City, Utah: Signature Books, 1987); R. Laurence Moore, Religious Outsiders and the Making of Americans (New York: Oxford University Press, 1986); Bret E. Carroll, Spiritualism in Antebellum America (Bloomington, Indiana: Indiana University Press, 1997); Ann Braude, Radical Spirits: Spiritualism and Women's Rights in Nineteenth-Century America (Boston: Beacon Press, 1989); and, David Chapin, "Exploring Other Worlds: Margaret Fox, Elisha Kane, and the Antebellum Culture of Curiosity," (Ph.D. diss, University of New Hampshire, 2000),

${ }^{17}$ Butler, Awash in a Sea of Faith,236-37. On the antebellum religious ferment in general see also: Nathan 0 . Hatch, The Democratization of American Christianity (New Haven: Yale University Press, 1989); Robert H. Abzug, Cosmos Crumbling: American Reform and the Religious Imagination (New York: Oxford University Press, 1994); and, Johnson, Shopkeeper's. 18

David Brion Davis. "Some Themes of Counter-Subversion: An Analysis of Anti-Masonic, Anti-Catholic, and Anti-Mormon Literature," The Mississippi Valley Historical Review, vol. 47, vol. 2 (Sept. 1960), 224. Davis ascribes the use of these themes to anxiety over social and economic change in an era of national expansion as well as nativism. Kenneth Winn, however, sees the issue of "republicanism" coming 
into the anti- literature only after the LDS arguments in defense of the Church were made on those grounds. See: Winn, Exiles, 4-5. I argue that while these issues were certainly inherent in much of the usage, that the fundamental issue was proscribing cultural boundaries. 19

Elson, Guardians, 340 .

${ }^{20}$ Among the frequent comparative passages in schoolroom histories and readers that reinforced the idea that both America itself and the nineteenth century heralded an age of reason and progress, see especially: Charles Goodrich, $A$ History of the United States of America, accompanied by a book of questions and supplement by Reverend Joseph Emerson $35^{\text {th }}$ ed. (Boston: Richardson, Iord and Holbrook, 1829), 68; Lilly, History, 132; S.Goodrich, First Book, 43; and, Hawks, History, 210.

${ }^{21}$ Elson, Guardians, 41.

22 Ibid., 47. See also: C.A. Goodrich, United States, 23; and, Joseph Worcester, Questions and Supplement to Goodrich's History of the United States (Boston: Richardson and Lord, 1829), 90.

23 Richardson, Reader (1813) quoted in Elson, Guardians, 44.

${ }^{24}$ Rev. J.I. Blake, A Geography for Children (Boston: Richardson, Lord and Holbrook, 1831), 60. See also: Alexander, Reader, 187; and, By a Teacher, The Village School Geography. $3^{\text {rd }}$ ed. (Hartford, Conn.: Reed and Barber, 1837), 43.

${ }^{25} \mathrm{~S}$. Augustus Mitchell, A System of Modern Geography (Philadelphia: Thomas, Cowperthwait and Co., 1843), 31 . For the same sentiment, see also: Benson Lossing, A Grammarschool History of the United States: From the Discovery of America to the Present Time (New York: Sheldon and Company, 1869), 65; and, George Payn Quackenbos, American History for Schools (New York: D. Appleton and Co., 1879), 67.

26 Gordon S. Wood, The Radicalism of the American Revolution (New York: Vintage, 1991), 363 quoting Judge Addison of Pennsylvania and Isaac Chapman Bates of Massachusetts. ${ }^{27}$ For a discussion of this in relation to the Matthias case, see: Johnson and Wilentz, Kingdom, 152. In relation to the LDS, see: Winn, Exiles, 73. 
28 Ibid. For the purposes of this chapter, which deals with the period from 1830 s through the 1890 s, I will define these ideas as related to "American" identity rather than "republican ideology." Although many of the debates include the term republican as understood by the combatants and appeal to his vision of that philosophy, I argue that by the 1830s the invocation of "republicanism" itself was a metaphor of sorts. Evidence for this is in the competing visions found in the debates. The reader is referred for a fuller elaboration on the divisions in American society on its meaning in the 1830s onward within the controversial literature on Mormonism in particular (although Winn makes no such claim for metaphor status in regard to republicanism). See also: Winn, Exiles, Introduction.

${ }^{29}$ Braude, Radical, 10.

${ }^{30}$ New York Herald, January 23, 1850.

${ }^{31}$ Joseph Smith's family lived in Topsfield, Essex County, Massachusetts near Salem for at least four generations by the early nineteenth century. See: Shipps, Mormonism, 4-5 for genealogical information.

32 Jeffrey A., "European Emigration and New England Puritanism, Southern Literary Messenger 37, vol. 8 (August 1863), 467.

33 Braude, Radical, chapter 1.; Butler, Awash, 25.

34 "Modern Necromancy," The North American Review 80, vol. 167 (April 1855), 513.

${ }^{35}$ Butler, Awash in a Sea of Faith, 252-54. ${ }^{36}$ Ibid., 253.

${ }^{37}$ Braude, Radical, 7; Butler, Awash in a Sea of Faith, 253. For this reason it is unknown exactly how many Americans ever regularly or occasionally dabbled in Spiritualist practices.

${ }^{38}$ Braude, Radical, 2.

${ }^{39}$ Butler, Awash in a Sea of Faith, 253.

${ }^{40}$ David Chapin, "Exploring Other Worlds, 2. Chapin says that "antebellum Americans wanted to be both educated and amused by knowledge." 
${ }^{41}$ Carroll, Spiritualism, 5. Alternately, in his study of the "religious imagination" as the foundation for antebellum reform, Robert Abzug argues that neither religion nor reform was necessarily based in secular concerns despite rapid changes in nineteenth-century America, but rather a true search for meaning in a religious sense.

${ }^{42}$ Butler, Awash in a Sea of Faith, 253. Butler argues as well that Spiritualism became a "cultural curiosity" by the late nineteenth-century as well because it never

"transcended the barriers of class and race." Ibid., 255. That it also drew from an overwhelmingly Protestant base is undoubtedly a function of demographics in the United States at the time but also accounts for ministerial opposition. ${ }^{43}$ John W. Hurn, "Letter to the Editor," New York Tribune, February 25, 1850.

44 "A Convention of Spiritualists," Philadelphia Public Ledger, August 11, 1852.

45 "Mesmer and Swedenborg," United States and Democratic Review 20, vol. 104 (February 1847), 107.

${ }^{46}$ See, especially: New York Daily Tribune, November 29, 1849; December 5, 1849; and, New York Herald, January 23, 1850. Although the Herald would reverse its position by late spring and claim that the whole enterprise was "supported chiefly by the Tribune and The Sun, those organs of all kinds of isms and humbugs." "Humbugs of the Day-The Rochester and Stratford Spirits Coming to Town," New York Herald, May 9, 1850.

47 Butler, Awash in a Sea of Faith, 254.

${ }^{48}$ Benjamin Park, "Letter from New York," Southern Literary Messenger 16, vol.7 (July 1850), 450. Some critics, like " $W$ " in a letter to the editor of the New York Tribune on February 4, 1850 prior to the arrival of the Fox sisters in New York City were more direct in their condemnation and charges of fraud: "these girls would rather tell a lie than the truth."

49 "Curiosities of Puritan History: Witchcraft," Putnam's Monthly Magazine 2, vol.9, 251. 
${ }^{50}$ William A. Hammond, "The Physics and Physiology of Spiritualism," North American Review 110, vol. 227 (April 1870), 258.

51 "Forthcoming Dramatic Novelty," United States and Democratic Review 32 (June 1853), 551.

52 Letter to the Editor, New York Daily Times, June 1, 1853. Joseph Jastrow's call for scientific investigation in the 1880 s long after others had relegated to Spirit communication to the cultural junk heap. He said that until science proved or disproved the claims, science was not meeting its "moral mission." And, to ridicule without full investigation brings to mind "the witch-burning by pious worthies of two centuries ago." See: Joseph Jastrow, Ph.D., "The Problems of 'Psychic Research," Harper's New Monthly Magazine 79, vol. 469, 77.

53 "A Convention of Spiritualists," Philadelphia Public Ledger, August 11, 1852. See also: Allen, "The Credulity of the Times," Southern Literary Messenger 20, vol.6 (June 1854), 343; George M. Beard, M.D., "The Psychology of Spiritism," North American Review 129, vol.272 (July 1879), 78;

54 The behavior of the spirits contacted came under criticism as well for "behaving no better than loafers and rowdies up town on New Year's Eve." "The Disembodied Spirits at Rochester," New York Herald, January 23, 1850. ${ }^{55}$ For a discussion of "fanaticism" in relation to an excess of religious enthusiasm and its believed relationship to insanity, see: David J. Rothman, The Discovery of the Asylum: Social Order and Disorder in the New Republic (Boston: Little and Brown, 1971); Ronald L. Numbers and Janet S. Numbers, "Millerism and Madness: A Study of 'Religious Insanity' in Nineteenth-Century America," in Ronald L. Numbers and Jonathan M. Butler, The Disappointed: Millerism and Millenarianism in the Nineteenth Century (Bloomington: Indiana University Press, 1987). For contemporary commentary on the issue, see: Amariah Brigham, Observations on the influence of Religion upon the Health and Physical Welfare of Mankind (n.p.: Boston, 1835); and David Meredith Reese, Humbugs of New York: Being a Remonstrance Against Popular Delusion (New York: John S. Taylor, 1838). 
${ }^{56}$ Reese, "Humbugs," 15.

57 "The Disembodied Sprits at Rochester," New York Herald, January 23, 1850.

${ }^{58}$ (Review) "Carpenter's Mesmerism, Spiritualism, etc.," North American Review 125, vol. 258 (September 1877), 390. ${ }^{59}$ Beard, "Psychology," 71.

${ }^{60}$ (Review) "To Diamonion, or the Spiritual Medium," The National Era, 6, vol.310 (December 9, 1852), 200. Although this review is unsigned, it may either be by whittier or influenced by his extensive use of Salem within his antislavery poetry and prose within the paper which he also edited. In this article the author makes no fewer than five analogous references to salem and Spiritualism.

61 "Are the Phenomena of Spiritualism Supernatural," New Englander and Yale Review 6, vol. 310 (May 1860), 400.

${ }^{62}$ Ibid., 405.

${ }^{63}$ Ibid.

${ }^{64}$ Adams, Abridgement, 160. Similar sentiments are found in: C.A. Goodrich, United States, 68 and Hawks, History, 150. 65"Necromancy," 523.

${ }^{66}$ Ibid., 524. Clairvoyance was also occasionally mentioned with Spiritualism as "repeating the history of witchcraft." Such things "Cotton Mather loved." See: George M. Beard, M.D., "The Delusions of Clairvoyance," Scribners Monthly 18, vol. 3 (July 1879), 433.

67"On Somnambulism," The Living Age 63, vol. 801 (October 1, 1859), 3.

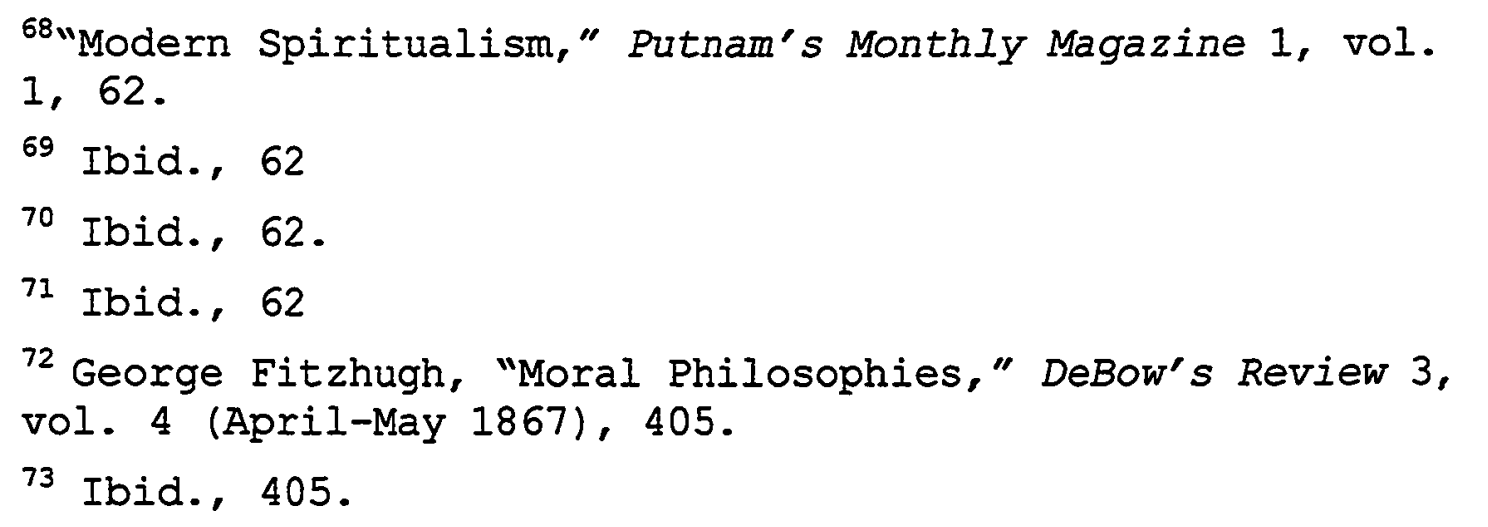


${ }^{74}$ For a general overview of the history, practices, and opposition to Joseph Smith and the Church of Jesus Christ of Latter Day Saints, see: Bushman, Joseph Smith; Winn, Exiles; Shipps, Mormonism; Givens, Viper on the Hearth; Quinn, Early Mormonism; Moore, Religious Outsiders.

${ }^{75}$ Allen G. Campbell, "Utah. Haw it a Republican Form of Government?" Century 23, vol. 5 (March 1882), 712.

76 "Matthias and his Impostures," 325.

77 "The Mormons in the Wilderness," The North Star (Rochester), March 3, 1848.

${ }^{78}$ Howe, Unvailed, ix. Howe's book, according to Kenneth Winn, became the source for anti-Mormon writers well into the twentieth century. As Howe actively sought testimony in the form of affidavits from Smith's former neighbors, his projects took on the aura, as he intended, of careful and objective research.

${ }^{79}$ For general histories of the church, see: Bushman, Joseph Smith; and, Shipps, Mormonism.

${ }^{80}$ Winn, Exiles, 73.

81 "The Many and The Few," Ladies Repository ,526. It was also called "a sort of epidemic insanity," see: "Theocracy," 393. "The Mormons," Southern Literary Messenger 17, vol.3 (March 1851), 174.

${ }^{82}$ Jeffrey A., "European," 467. For similar references, see: "Two Prophets," 315; and, (Review) "History of the United States," United States Democratic Review, 26 (January 1850): $44-49$.

83 "Comment on the Times," 405.

84 (Presbyterian) Philadelphia Christian Observer, (October $25,1844), 170$.

85 "The Two Prophets of Mormonism, Catholic World 26, vol. 152 (November 1877), 229. For a similar comment in the preface to a history of Salem witchcraft, see: Samuel G. Drake, The Witchcraft Delusion in New England vol. 1 (New York: Burt Franklin, 1970), 1xii-lxiii. Drake found human progress disappointing when looking from 1692 Salem to the 
"transparent jugglery as that which has people the Salt Lake Regions."

${ }^{86}$ Quotes in order: Edwin De Leon, "The Rise and Progress of the Mormon Faith and People," Southern Literary Messenger 10, vol. 9 (September 1844), 535; Howe, Unvailed, 84. De Leon, appalled at Mormons' superstitious beliefs, displays some interesting contemporary beliefs of his own. Of Joseph Smith, De Leon notes: "his head is phrenologically bad." De Leon, "Rise," 536.

${ }^{87}$ Quotes in order: C.C. Goodwin, "The Mormon Situation," Harper's New Monthly Magazine, 63 (October 1881), 759; De Leon, "Rise," 528; E.D. Howe, History of Mormonism; or, A Faithful Account of that Singular Imposition and Delusion, with Sketches of the Characters of its Propagators

(Painesville, Ohio: Published by the Author, 1840), 399.

${ }^{88}$ Quotes in order: Eugene Young, "Revival of the Mormon Problem," North American Review 168, vol. 509 (April 1899), 482; "The Professor at the Breakfast Table," The Atlantic Monthly 3, vol. 19 (May 1859), 617.

${ }^{89}$ Ibid.

${ }^{90}$ Charles G. Leland, "The Ash Tree," Continental Monthly 2 (December 1862): 684 .

${ }^{91}$ Goodwin, "Situation," 759.

${ }^{92}$ Elson, Guardians, 288.

${ }^{93}$ Willard, History, 337. See also: W.H. Venable, A School History of the United States (Cincinnati: Wilson, Hinkle and Co., 1872),90; and, Quackenbos, History, x.

94 Rollin Lynde Hartt, "The Mormons," The Atlantic Monthly, 85, vol. 508 (February 1900), 174. For similar descriptions of Utah territory demographics, see: Goodwin, "Situation," 759.

${ }^{95}$ Congress, House of Representatives, Territorial

Representative T.A.R. Nelson of Utah, "Polygamy in Utah," 36 th Cong., Ist sess. Congressional Globe (April 5, 1860). 96 Jeffrey A., "European," 467.

${ }^{97}$ Goodwin, "Situation," 759. 
98"Disruption of the Federal Union," DeBow's Review 30 (April 1861): 432 .

99"Theocracy," 392.

${ }^{100}$ Elson, Guardians, 285. For examples within schoolbooks, see especially: Lossing, History, 42; [Joel Dorman Steele], A Brief History of the United States, (New York: A.S. Barnes, 1881), 55; and, William McGuffey, McGuffey's New Eclectic Spelling-Book, (Cincinnati: Sargent, Wilson and Hinkle, 1865), 40 .

${ }^{101}$ For sampling of the schoolbooks which emphasize English control or influence over the courts at Salem, see: Adams, Abridgement, 164; Webster in Morse, Geography, 192; and, Olney, United States, 70.

ivz John W. Barber and Henry Howe, Our Whole Country: or, The Past and Present of the United States. Historical and Descriptive. 2 vols. (New York: George F. Tuggle and Henry M'Cauley, 1861), 1460; and,

${ }^{103}$ Goodwin, "Situation," 756.

${ }^{104}$ Campbell, "Utah," 712.

${ }^{105}$ Ibid.

${ }^{106} \mathrm{~J} . \mathrm{D}$. Bell, "The Many and the Few," The Ladies' Repository 15, vol. 9 (July 1859), 527.

107 Goodwin, "Situation," 760.

${ }^{108}$ Congress, House of Representatives, Territorial

Representative W.H. Hooper of Utah speaking on Utah

Statehood, Congressional Globe, 41st cong., 2nd sess.,

(March 22 and 23, 1870).

109 Howe, Unvailed, 14.

110 Winn, Exiles, 81.

${ }^{111}$ Campbell, "Utah," 712.

112 "Theocracy, 392. See also: Campbell, "Utah," 712.

113 Francis Lieber, "Civil Liberty and Self-Government," The Southern Quarterly Review 9 (April 1854), 323.

114 "A Nation's Right to Worship God," The Princeton Review

31 (October 1859), 672. 
115 "Ghosts in our Foreign Policy," The Century 23, vol. 5 (March 1882), 779.

116 Ibid.

117 "A Comment on the Times," 409 


\section{CHAPTER THREE}

\section{PURITANS, WITCHES, AND SOUTHERN RHETORIC}

On February 16, 1849 Democratic Congressman Henry Bedinger of Virginia had had enough. Enough of hearing slavery described in the House as a "curse" on Southern culture and morals. More than enough, especially, of Massachusetts Representatives Horace Mann and John Palfrey and their "fanatical abolitionist" friends in the chamber who took every opportunity to make negative comparisons between the North and the South. As Bedinger stood on the floor of the House of Representatives, he waved Elwood Eisher's recently published pro-slavery speech which used statistical data to "prove" that slavery resulted in both more prosperity and a superior moral climate. ${ }^{1}$ As for Massachusetts, he concluded, "she is unquestionably, sir, a great state, and some of her Representatives on this floor seem to know it."2 But, for those members who were unacquainted with the glories of Massachusetts history and culture, he offered an instructional historical episode: "there witches... were, 'in the brave days of old,' burned, literally by the cord!"3 
The association of Salem witchcraft with "fanatical" abolitionism was not a singular example of hyperbole. It represented an emerging rhetorical strategy among proslavery advocates designed to address the "cruel slaveholder" figure who so dominated Northern discussions of slavery. ${ }^{4}$ Southern writers and politicians advanced a particular version of the "Puritan" toward the same ends. The addition of the idea that witches were burned in Salem in 1692 was new. No historical or literary account ever claimed such a fate for the convicted Salem witches. It was a charge which would, through repetition in these debates over slavery, become part of the American popular imagination. The method of state execution in 1692 Salem as in most of nineteenth-century America was hanging. But, by claiming that Puritans burned those convicted of witchcraft, the image of injustice and barbarity lent the illustration more horror and thus more power. ${ }^{6}$

By invoking the "witch" and the "Puritan," Southern writers and politicians played their part in the escalation of the emotional climate that historian Avery O. Craven has described as an essential pre-condition for the Civil War. Political failures, weak men and missed opportunities were less to blame for the Civil War, he asserted, than heightened "emotions, cultivated hostilities, and ultimately of hatred between sections. Bloodshed was "necessary" 
because men associated their rivals with disliked and dishonorable symbols, and crowned their own interests with moral sanctions...they were both fighting mythical devils."7 Southern invocations of seventeenth century New England witchcraft and the response it garnered, in both the North and the South, certainly supports such a conclusion. But, in addition, it provides a view of how the metaphor of Salem witchcraft became a permanent part of American cultural discourse.

Indeed, ante-bellum Southern readers of newspapers, periodicals, pamphlets, and books were exposed to much escalating and emotionally charged rhetoric as the struggle over new western territories deepened in the wake of the Mexican-American War and the oregon treaty. The invocation of Salem witchcraft within the dialogue between sections was designed by Southern writers and politicians not merely to defend slavery, but to illustrate the cultural superiority of the society that had been built upon slave labor. The finer points of the legality of the 1820 Missouri Compromise did little to stir any great emotional response in an audience. To speak of the South as having offered a larger contingent of volunteers than the North in the recent war and of having to endure the subsequent "insult" of being asked to "consent to arbitrary and insolent restrictions" by the banning of slavery in that land was effective. But 
most persuasive of all was to remind constituents or readers that the same men who called slavery a "curse" on the culture of the South were themselves descendants of men who burned "witches" and to emphasize how that showed "there are some monstrosities we never commit" was more effective still. 8

The Southern Congressman or editorial writer who called up the seventeenth-century Massachusetts Puritan to stand-in first for the abolitionist and finally for the undifferentiated Northerner, of course drew upon a figure Iamiiiar to his audience. For the "Puritan" of Massachusetts Bay Colony was, as we have seen, a fixture in nineteenthcentury school histories --North and South-- as was the 1692 episode of Salem witchcraft. Although by 1850 there still was nothing approaching universal common school education in the southern states, approximately two thousand private academies served an estimated 70,000 students. ${ }^{9}$ Southern children used the same schoolbooks as their Northern peers when they read Samuel and Charles Goodrich, Emma Willard, Salma Hale, John Frost, and other authors who featured a retelling of the Salem story framed in condemnatory terms. ${ }^{10}$ Those schoolbooks also consistently cast the Salem Puritan as "English" or "European." The proof that this interpretation shaped American thinking across sections is evident in a belated transition in Southern writing and 
rhetoric that moved the Puritan figure from an English into an American context.

The "Puritan" had, of course, a presence in Southern letters and political rhetoric that extended back to the 1830s. The popularity of Sir Walter Scott's Waverly novels, as Drew Gilpin Faust and others have argued, nicely dramatized the Southern feeling of cultural and economic domination by the North. ${ }^{11}$ Within this imaginary literature Southerners comforted themselves with visions of their Norman and Cavalier antecedents and images of Northerners as descended from brutish Saxons and Puritans. This fictional refuge, much like Scott's Highlanders fighting the aggressive Englishman, allowed Southerners to retreat into a fantasy of self-assured innate cultural superiority that was conferred by such symbols. The conflict between Puritans and Cavaliers in these sources drew on myths about the origins of the original settlers in each section and borrowed directly the model of the royalist Cavaliers not from Virginia's Tidewater plantations but from the 1640 s era of the English Civil War. Thus the adaptation of the Cavalier as a symbol of gentility and cultural achievement attached new meanings to enduring symbols in the old South. For these sources personified the aggressive Puritan type who traditionally posed a threat to the South prior to 1849 not 
as Massachusetts Bay Colony's Cotton Mather but as England's Oliver Cromwell.

This mythology would become central to the creation of a Confederate nationalism by 1860 . It did so first by intensifying the Southern identification with the Cavalier through the transformation of the Puritan in the Southern imagination from English to New Englander. Once that was accomplished the besieged Cavalier of the South was provided with a critical historical past for Confederate nationalism. It was one that offered "an interpretative framework in which to view the Civil war as a struggle between great moral-historical principles."12 It also provided an alternative to the overwhelmingly Northern myth of national origin based on the Puritan founding in Massachusetts. The resurrection of these seventeenth-century English political antagonists and their permanency in the Southern mind was fully established by their versatility in expressing critical values in opposition to the North.

Still, rhetorical șirmishes prior to the most vitriolic phase of the sectional crisis in the 1850 s rarely laid out a fundamental dichotomy in cultural development between the two sections. Rather, most discussion offered an exposition of the virtues of the Southern descendant of the Cavalier, while drawing explicit comparisons with the morally inferior Puritan strain among Northerners. The full 
potential of the Puritan as a symbol of essential Northern autocratic and aggressive tendencies, however, was only realized by placing the model firmly on American rather than English soil. By transferring the symbolic threat based in English history to one that had concrete American connections, the idea of real and imminent danger was intensified. Salem witchcraft thus became crucial to a Southern rhetoric that already employed a Puritan-Cavalier symbolism to express dissatisfaction with other issues of social, economic and cultural development. In addition, the long association of Salem witchcraft in American history books as essentially English or European in origin completed the idea that the South exemplified "American" virtues while the North was effectively steeped in European sins of tyranny, or so Southern audiences were encouraged to believe."13

A particularly well-informed Southerner who followed the debates over religious innovations in newspapers and periodicals from the mid-1830s onward would, of course, also be familiar with the use of Salem witchcraft as a metaphor. Southern and Northern pamphlets, editorials, and books promoted the idea that there were real dangers to society in religious movements that ranged from the Prophet Matthias to Mormonism. Tolerance, that great American value of the schoolroom textbook, it was argued, was never meant to 
extend to religious "delusions." Opponents of these religious innovations already had found Salem witchcraft to be a useful shorthand to convey the idea that there were limits to acceptable American religious practices. These limits were necessary to hold irrationality, public hysteria, and even foreign influences at bay.

By the 1850s, then, it was relatively easy to refine the model of Puritan-Cavalier conflict for the current political crisis. Additional negative traits could be assigned and the old references to Cromwell and the Puritans of the English Civil War period could be made more explicit and American. The "story" of Salem witchcraft was not only familiar to Southern audiences but it was, as we have seen, saturated with provocative language. Pro-slavery advocates wished to associate abolitionists and their goals with: "hypocrisy," "delusion," "intolerance," and, especially, the catch-all phrase tinged with irrationality and violence, "fanaticism." Each vice could be vividly illustrated by a simple association with Salem witchcraft.

Thus, as in the religious controversies where despised religious sects were compared to salem witchcraft and described as dangerous "delusions," so too could disturbing political innovations like abolition be similarly joined to witchcraft. In this way, Salem became a persistent rhetorical theme within the current political crisis between 
sections. In melding a Northern abolitionism that was increasingly taking on a moral and religious-based rationale, with the historical and fictional Puritan symbol, as well as Salem witchcraft, the Southern writer or politician found an apt candidate to promote as a Northern "dishonorable symbol."

Provocative language describing Salem witchcraft had already emerged in some Southern publications by the 1830 s through references to the English Puritan as "fanatical" abolitionist. These writings were a direct response to the growing strength and focus of organized abolition activities in the North. The association was only heightened as abolitionists tried to use moral suasion to create a sense of a divinely inspired and guided mission in its adherents. ${ }^{14}$ Thus William Drayton's 1836 book The South Vindicated from the Treason and Fanaticism of the Northern Abolitionists attempted to instill in his Southern readers' minds the essential nature of the abolitionists and their ultimate goals.

To Drayton, some in the abolition movement were "actuated by honest fanaticism; others are impelled by a sinister ambition, by hatred of the South, or by a natural proneness "to make trouble" but, from Ohio in the west, to New York in the east "all are evil---all are mad!"15 Abolitionist publications, he noted, revealed that "the 
days of Cromwell were revived, and that his fanatical followers... were abroad in the land."16 Certainly Drayton's warning of a threat to the South through Northern political domination relied on a broad depiction of abolitionists as "Northern" but even at this date we can see the beginnings of the transformation of the Puritan symbol would make from English to American. In this volume, the New England Puritan was evoked by Drayton's description of sermons across the northern states as being "almost nasal with cant."17

The connection between the New England Puritan and abolition became increasingly common within popular southern periodicals in the 1840s. The author of an unsigned editorial comment in the Southern Literary Messenger directly linked the New England Puritan with abolition while ridiculing those who would mount a "spirited defense of the character of the people of New England."18 A decade before territorial questions sharpened both hostilities and metaphors, the writer revealed the true issue of contentionabolitionist "enthusiasm." Others, he noted, have labeled it "fanaticism" or even referred to the "bigotted [sic] despotism with which they domineered over all who departed from their stern creed."19 The contemporary New Englander had "all the leading traits of their progenitors ...the same vein of ultraism and the same insolent pretension to impose their own dogmas, and their own notions upon others. Take 
for sample that real fanaticism, that fever, or rather, frenzy of abolitionism." 20

"G" directly connected the Puritans to Salem witchcraft in making the case for New England extremism. "Fanaticism," he noted, "appears to form an essential trait in the New England character"-the proof of which was "the old women [who] were burnt as witches." Such a spirit of fanaticism always needed a "discharge," G. claimed. "This it has at the present time found in abolitionism."21 An 1845 reviewer of Religion in America in The Southern Quarterly Review fended off any potential suggestions that the seventeenth-century English colony of Virginia also had laws against witchcraft on the books by noting that in Virginia they were "mildly," if ever, executed. ${ }^{22}$ Virginia, he implied, was well on the road to an American sense of reason in the 1600s. By contrast, the ancestors of contemporary New England Congregationalists, and by implication the current vocal Massachusetts abolitionists, were still thoroughly English and so responsible not only for the "banishment of Roger Williams" but also for the "execution of witches." Those, he ominously declared, were "some of the fruits of their principles."23

During the 1849 Congressional debate, "fanaticism" was a word in use but not yet entirely identified with the abolitionist much less Salem witchcraft. That it was rapidly 
becoming so was evident in the complaint of Democrat Abraham Venable of North Carolina three days after Henry Bedinger's remarks. Venable claimed to be struck by "a sickly sensibility" of late in the House that members addressing the question of slavery were often "alluded to as agitators and fanatics." 24 Indeed, the identification of Salem witchcraft with the abolitionist in Bedinger's speech soon inspired a number of similar comments in Southern journals.

Defensive statements by Northern and abolitionist sources furthered popular use of the Salem metaphor to describe anti-slavery activism. Both Horace Mann and John Palfrey of Massachusetts responded to Bedinger's remarks directly on the floor of the House on February 26, 1849. Mann objected to the turn in the tone of the debates by citing the "torrent of abuse" that Bedinger and several others had heaped on Massachusetts. He asked: "Is a state to have no benefit from a statute of limitations? Is a crime committed by ancestors to be forever imputed to their posterity?"25 Perhaps, Mann suggested, the Virginian could understand the impetus for Massachusetts' penchant for abolition by considering it an act of atonement for departed victims of other historical wrongs. John Palfrey mounted a far more aggressive defense of his state's honor. "There has crept of late into this discussion," he observed, "a style 
of remark...Gentlemen incline to invite us to the investigation of historical problems" for they "imagine that if they can point out some fault in our ancestors, they do something towards refuting our reasonings." 26 Palfrey, who would later publish his own well-received History of Massachusetts, especially objected to Bedinger's "violent hyperbole" and insisted that he found no reason for shame in his New England ancestors' actions. In fact, Palfrey turned the attack into an opportunity to advance abolitionism. He mused that being "challenged about the past" reminded him of that "stern but constant ancestry" which continually renewed his anti-slavery convictions and gave him the courage to press onward in the fight.

The introduction of Salem witchcraft gave fresh energy, as well, to a variety of Northern and Southern editors and politicians in $1849-50$ as the Congressional speeches appeared in print. In an obvious reaction to the debate, a February 1849 issue of National Era, a Washington based abolitionist newspaper co-edited by John Greenleaf Whittier, echoed Palfrey's remarks in an article on "The Reform School in Massachusetts."27 In it, Whittier praised the idea of "reformation" over punishment and connected Salem witchcraft directly to the idea of progress in penal reform. Whittier celebrated man's progress by contrasting the new methods used by the school to the days when crowds were "convulsed 
with grim merriment... [as they] enjoy[ed] the spectacle of an old man enduring the unutterable torment of the peine forte et dure---pressed slowly to death under planks---for refusing to plead to an indictment for witchcraft." 28 Likewise, the arrest of a Wesleyan-Methodist circuit rider in Virginia inspired a report in May that invoked Salem. This article suggested that as long as Virginia had censorship statutes "let her never talk of the hanging of witches by Massachusetts a hundred years ago." 29 Nor was the National Era adverse to printing speeches of Mid-Western congressmen whose stand on slavery extension was based less on abolition than on the rights of "free white laboring men," ${ }^{30}$ if it supported the general cause. Congressman Kinsley Scott Bingham of Michigan objected to the admission of California to statehood if it meant establishing "a great slave mart on the shores of the Pacific." Slavery itself was, in his view, "a living libel on the Declaration of Independence." Bingham was convinced that one day slavery would be known, like the "burning of witches," as something which "an enlightened age condemns." 31

The African-American press was burdened by none of the conflicts that bedeviled Whittier or the Massachusetts congressmen. They could ignore the defense of Massachusetts' honor to cut directly to the real issue under debateslavery. Picking up the theme of Salem witchcraft from the 
white press, ex-slave Frederick Douglass' Rochester, New York newspaper The North Star found Salem witchcraft useful in its own critique of slavery. ${ }^{32}$ "In what respect," Douglass asked in July of 1849, as he pondered the issue of slavery in the District of Columbia, was the belief in witchcraft in those far-away days "one whit more absurd, extravagant, foolish, or wicked" than the contemporary belief in slavery? In fact, "dig[ging] up old superstitions" like the episode of witchcraft in Massachusetts was a waste of time. Why not, he argued vigorously, "find full occupation in exposing and combating those that remain?" A letter to Douglass printed later that same year described the current popular interest in hypnosis and suggested that perhaps "the potency of mind upon mind" might convince slave-holders to abandon the institution. If not, then at the very least, believers should perhaps experiment in other ways with their "favorite science" by using the contemporary "subject of slavery as well as the Salem witchcraft to illustrate" the powerful influence of one mind upon another. ${ }^{33}$

During those same autumn months of 1849, Whittier continued his efforts to reconcile Massachusetts' witchhunting past with its abolitionist present. Whittier advanced one of the most novel connections between slavery and Salem witchcraft before abandoning his short-lived 
attempt to refute or reverse the metaphor in the pages of the National Era. His editorial comment in November 1850 considered the standard Southern argument that slavery "like the cotton-plant, is confined by natural laws to certain parallels." New England's growing opposition, or so the argument went, was based not on virtue but on economic selfinterest. ${ }^{34}$ Whittier countered that slavery was in reality a product of "pride and lust and avarice" and had prospered at different times in every latitude from the steppes to the city. Indeed, he said, it prospered in Massachusetts despite an ordinance banning it in 1649. According to Whittier's view of Massachusetts history, lax enforcement of the law allowed slavery to become established on an "execrable foundation of robbery and wrong." But, the "retributive dealings of Providence" set things right again. Evidence of this could be found in the first of the accusations of witchcraft in Salem which "originated with the Indian Tituba, a slave in the family of the minister." Is it any wonder, he concluded, that Massachusetts fears the Fugitive Slave Act? He left the reader to consider the application of this "instructive fact." 35

Witchcraft also appeared as the subject of one of Whittier's many anti-slavery poems which, like his editorial comments, turned the metaphor around to emphasize the theme of progress and redemption. Calef in Boston, 1692 imagined a 
meeting between Cotton Mather, the Puritan clergyman most associated in the popular mind with the Salem trials and their subsequent defense, and Boston merchant Robert Calef, who just eight years after the trials published a critique of the procedures used and the men who conducted them. In Whittier's fantasy Calef tells Mather that while there were a few eternal verities, belief in witchcraft was not one of them. Instead such ideas prevented man's intellectual progress:

Falsehoods which we spurn today Were the truths of long ago Iet the dead boughs fall away, Fresher shall the living grow.

In Whittier's poem, the minister remained resistant to the end in this exchange, but the poet reminded his readers that ultimately, the Boston merchant's struggle to persuade Mather was validated by God himself as men came to know the truth:

The Lord hath blest the seed Which that tradesman scattered then And the preacher's spectral creed Chills no more the blood of men. ${ }^{36}$

Whittier's purpose here extended beyond echoing Palfrey's demand that men not be asked to pay for the sins of their fathers. In using Calef as his spokesman, Whittier provided a subtle reminder that it was not only a Boston man but a merchant who challenged the witchcraft trials in their 
own day. As the most ardent of abolitionists, Whittier warned that one day future generations would view the intransigence of slave-holders and of Southern Congressmen as men now did belief in witchcraft. The slaveholder, he suggested, was as rigid in his own erroneous faith in slavery as Mather was in his of witchcraft. And, in concert with Palfrey's comments on the floor of the House of Representatives, Whittier's held out the hope that repentance and reformation on slavery could result in moral regeneration for the slave-holder.

This was exactly the sort of blatant moralizing that Southerners like the editor of New Orleans based DeBow's Review grew increasingly tired of hearing. In perusing the recently delivered Edinburgh Review in 1851, J.D.B. DeBow found a troubling tone in its reviews of American books. The journal, he complained in an editorial note, increasingly "considers New England the United States, and New England is the land of abolition." Therefore, he acidly observed, it cannot be praised enough. The Southern states on the other hand, are "tolerated only because they may some- day be converted, and turned from the error of their ways, by negro-loving, witch-burning New England, into the paths of redemption and political salvation."37

If J.D.B. DeBow was finding no comfort overseas, he knew he had a consistent political ally of sorts in the 
United States Democratic Review. The Democratic Party organ resisted both militant abolitionists and New England's politicians. In an unsigned article entitled "The Conspiracy of Fanaticism," the Review described New England as "more addicted to superstition and fanaticism" than any other section of the country. ${ }^{38}$ The Review carried the opportunity and the burden of maintaining a bi-sectional audience throughout the contentious 1850s. And thus, it never missed an opportunity to attack abolitionists. Ironically, for a party that rose on the populism of Andrew Jackson, it often showed a fear of "mobs" that would do credit to the most conservative Southern Whig. ${ }^{39}$ By 1855, the Democratic Review was claiming that the New England "hive is always full and always swarming." Indeed, this writer expected New England to combine with a foreign power once they had "exhausted all the means of declamation, sedition, and anarchy."40 For the "infuriated fanatics" of New England, the anonymous author added, there was not much distance between "moral and political treason."4I In one of its last articles before a party split between Northern and Southern Democrats resulted in its demise, the Democratic Review fired a last barrage at the "selfish and rapacious Yankee" who drove the more refined Englishman to colonial New York or Virginia in disgust as the Yankee remained in New England to enjoy such pursuits as "the pleasure of burning witches."42 
These references to "swarms," "hives," and "superstition" echo the familiar nineteenth-century interpretations of Salem witchcraft within the pages of history books, fiction, or the invective of other cultural controversies as dangerous and backward "delusions" which inflamed the population of Massachusetts with tragic results. ${ }^{43}$ And certainly warnings of potential "treason" reinforced the idea promoted in the Southern press about New England's essential un-American orientation on everything from slavery to homesteading legislation. But while the political rhetoric of the 1840 s and 1850 s relied upon a generalized demonization of abolitionists and Northerners, a few Southern writers used Salem witchcraft to support the notion that only a complete breakdown of reason alone explained abolitionism. One contributor to DeBow's Review in 1853 argued that all the "delusions of the North" no matter how "wild and furious the numerous outbreaks of our northern brethren in the way of 'Salem Witchcrafts'...including even 'abolitionism' itself,"44 were no more than curiosities so long as the consequences were confined to New England.

E. Boyden linked his argument to the on-going debates over religious innovations which had introduced Salem to controversial literature in the 1830s. Boyden advanced the idea of such episodes of public excitement as a "moral epidemic." Looking to history, he argued, we can see in the 
"witch mania... [how] honest men...took leave of their senses in pursuing pious and harmless old women to the death, under charges, by modes of trial, and upon evidence such as idiots only could well be supposed capable of listening." The fact that history was rife with inexplicable excitements such as "phrenology, mesmerism, clairvoyance, animal electricity ... and spiritualism" was a similar concern for "Nella" in the Southern Literary Messenger who attributed the spread of those superstitions, like the Salem "witch scare," to "credulity." While Nella could conclude that in comparison to Salem "no leaf of American History is so revolting," 45 Southern writers were deeply concerned about this latest Northern delusion and its potential consequences.

The Salem example thus seemed relevant to widespread anti-slavery sentiment, for like other "inexplicable excitements," both abolition and witchcraft reflected the mass insanity that resulted when the unscrupulous gained temporary sway over another's reason by fast talk and deceit, as did both witches and professional abolitionist agitators. Increasingly, the rhetorical emphasis was on the leaders of the abolition movement, their allies in the pulpit, and the effect of abolitionist activities on legislation. What was feared was "the tyranny of public opinion." So H.T. Tuckerman argued in his discussion of the 
persecution of both witches and Quakers by Puritans in an 1851 review of Hawthorne's works for the Southern Literary Messenger. Congressional imbalance and the resulting elimination of slavery was the "epidemic" many in the South feared would spread beyond New England if the abolitionists were successful in their efforts to sway "public opinion." Southern writers targeted abolitionist leaders as the 1850 s progressed in order to avoid alienating those Northerners who still had not fallen prey to what Southerners saw as ministerial collusion in promoting abolitionism. Perhaps Northerners might yet realize the danger of faliing under the "delusion" of abolition.

Salem surfaced, as well, in the immense Southern ire at ministerial participation in the anti-slavery movement. Such participation came in the form of direct political activity as in speaking out against slavery or petitioning Congress, and by supporting legal resistance on the grounds of conscience or "higher-law." Indeed, Cotton Mather, and to a lesser degree Salem minister Samuel Parris, were used as object lessons of the dangers of the "premium...offered for hypocrisy in an effort to gain power in a "religious" colony." 46

In an 1853 review of Bancroft's History of the United States, DeBow's Review raised the specter of Salem when noting contemporary clerical influence on abolitionist 
organizations. Cotton Mather, the reviewer fancifully claimed, was "hated by many and loved by none... haunted by the gloomy terrors of an evil conscience, and by the innocent blood which he had been instrumental in shedding." 47 With such "a persecuting spirit" at the head, the witch hunt proceeded until finally "the spirit of the people began to be roused," priestly influence was overthrown, and the tragedy ended. ${ }^{48}$ Undoubtedly, the reviewer was not adverse to the "tyranny of public opinion" if it served his own cause. J.D.B. DeBow's reading of the situation matched the escalating rhetoric, including that of his own journal. A poem about Northern ministers that accompanied his article finished with these lines: "beside the prayer-book on his desk/ the bullet mould [sic] is seen. "49

But even moderate to conservative non-Southerners had difficulty with the abandonment of the rule of law for the rule of conscience through the 1850s. Commodore Robert Field Stockton was asked by Daniel Webster in 1850 to comment on the issue of slavery extension to California. In his reply, Stockton agreed with Webster that on Constitutional grounds slavery could not be outlawed. Further, he believed that it was "the error of fanaticism" to rely upon individual conscience in such matters. For conscience was that which "burns the supposed heretic at the stake, or hunts down 
witchcraft." 50 Boston moderate Moses Stuart also objected to the imposition of a rule of conscience on political questions. "The hangers of witches among us surely had a conscience," he noted. Stuart went on to observe that "when judgment is kept down, and passion set up, men...can manufacture a conscience into any possible convenient shape." "Who has discovered and determined such a law?" he asked. $^{51}$ Samuel F.B. Morse wrote privately to his brother Sidney that abolition was "a fearful hallucination, not less absurd than...Salem witchcraft" and which has "darkened the moral atmosphere of the North. "52

A petition signed by more than 3000 clergymen against the proposed Kansas-Nebraska act in the United States Senate on March 14, 1854 likewise reinvoked the memory of Salem. The submission of this petition infuriated some Southern Senators who saw the clergymen as "usurping spiritual functions for the purposes of agitation."53 In May of 1854, Massachusetts Senator Charles Sumner added more fuel to the fire by offering additional petitions from sources which included Quakers in Michigan, as well as Baptist clergy and laity in Michigan, Indiana, New England, and New York. Sumner argued that if the senate could invoke God at will, then certainly the clergy could do so "without just criticism," ${ }^{54}$ as well. James M. Mason of Virginia immediately and strenuously objected to the involvement of 
the clergy as a "prostitution of their office to the embrace of political party."55 Clerical invocation of God in the petition texts and closing salutations, Mason insisted, carried a different authority than when laymen in the Senate did the same. Democrat Stephen Douglas of Illinois settled for categorizing anti-slavery petitions under clerical endorsement as "treason against the Constitution and the Union."56 Yet, by June of 1854, still more petitions signed by a wide spectrum of Bostonians were offered by Sumner and his Massachusetts colleague Julius Rockwell. Because of these petitions, Sumner became embroiled in a violent debate over two days with Mason which included Sumner's charge that Mason and Andrew Pickens Butler of South Carolina used "Salem as a slur on the state."57 Butler angrily replied that he wanted to respond to Sumner's latest comments there and then for if he took time to answer formally, he might be tempted to act "like a hyena...scratching at the graves in Massachusetts to take revenge." 58

By the mid-1850s very few Americans with any ties to New England apart from politicians, editors, and polemicists wanted to deal with the Salem charge with the notable exception of the New England Societies (NES). Salem witchcraft had been a thorn in the NES' collective side for over thirty years. A loosely knit organization with chapters 
in major cities throughout the nation, the NES was comprised of upper-middle class and professional men whose membership was based upon personal or hereditary ties to the region. ${ }^{59}$ Iargely social in character, the highlight of the NES year was the annual anniversary dinner with orations in honor of the December 1620 landing at Plymouth. The menus, speeches, and programs were widely reported on in local newspapers and often printed independently. As a central feature of these programs was a celebration of the New England founding and its values, the specter of Salem provided a constant provocation for the speakers to respond and defend the region. Indeed, the toasts and orations at the yearly December meetings provide a barometric reading of the antiPuritan atmosphere in the culture at large which was inevitably linked to the subject of Salem witchcraft. Reverend Leonard Bacon, as early as 1838, had not only met the subject of Salem head-on in his address before the New York City NES, but devoted a considerable portion of his remarks responding to what he perceived as the continual "invective and ridicule against those venerable men" 60 of colonial New England. "Did these men believe in witchcraft? Certainly they did." But, he inquired of his audience, should the Puritan be castigated because he did not throw off the "prejudices and terrors" of his age ${ }^{61}$ By 1847 , Charles Boynton, a minister who delivered the annual New 
England Society of Cincinnati address, complained that the very mention of Salem witchcraft was now "generally supposed to be the end of all controversy upon New England." ${ }^{62}$ Boynton undoubtedly voiced the frustration of the membership at large when he concluded: "there are thousands in our own country, whose prominent idea of the New England Puritans is, that they were a set of misguided fanatics or prating hypocrites, who sang Psalms on Sunday and hunted witches...through the week."63 Through the 1850s NES speakers wrestled with the "problem" of Salem. At the 1855 New York dinner the speakers were a study in contrasts. Physician Oliver Wendell Holmes, spoke of the need to proceed with caution on issues that threatened disunion, while minister John Pierpont called for active resistance in the name of the forefathers as both sought authority in ancestry for what they insisted was merely a reasonable course of action. The audience at the New England Society dinner in New York City was listening to a more politically charged program than was usual for their typically and determinedly non-controversial meetings. ${ }^{64}$ The Reverend John Piexpont directly addressed the Fugitive Slave Act by suggesting that the forefathers would be shamed by any descendant who helped send men back into bondage "because so bidden by laws that men have made."65 Oliver Wendell Holmes, Sr. in addressing the NES the same evening also dismissed 
talk of New England "ultraisms and heresies." In fact, Holmes claimed that "the land that has no enthusiasts, no fanatics, no madmen" is one that suffers from a sort of intellectual death. ${ }^{66}$

Charles Sumner, for his part, often reveled in the charge of "fanatic" and never avoided the subject of Salem witchcraft when he found it useful. Shortly after his debates with Butler and Mason, Sumner re-entered the fray in a September 1854 speech before the delegates at the first Republican state convention in Worcester, Massachusetts. In it he compared the hated Fugitive Slave Act to the Massachusetts witchcraft laws of the seventeenth century. Arguing that "nothing so abhorrent to reason and conscience should be regarded as constitutional and binding," Sumner likened resistance to the Fugitive Slave Act with resistance to witchcraft prosecution. In his sometimes tortured logic and fractured history, he claimed a "parallel between the law against witchcraft and the fugitive act" that was "not yet complete." What was ultimately needed to complete his envisioned historical "parallel" was for Congress to renounce the Fugitive Slave Act and serve as "the successor of that original general court, to lead the penitential march." 67 In a closing designed to hit all the local and national emotional high notes, sumner said that conscience was of God, but laws were of men. Since it was man's law 
"which hung witches at Salem---and which affirmed the constitutionality of the Stamp Act" ${ }^{68}$ resisting the Fugitive Slave Act was both a patriotic and religious duty.

Wendell Phillips, that most radical of Boston abolitionists, likewise happily donned the "fanatic" mantle before the Pilgrim Society at their annual meeting in December 1855. Linking the past with the most pressing controversy of the moment, the violent struggle over the Kansas territory then being waged between Free-Soil and proslavery settlers, he announced to loud cheers that the Pilgrims themselves would today "in 1855, [be] not in Plymouth, but in Kansas."69 Their only questions would be, "Is liberty safe? Is man sacred? They say, sir, I am a fanatic, and so I am."70 But Phillips, however irrepressible he often seemed to his enemies, was also less apologetic for the excesses of history. He claimed that "the Puritans...hung the witches; George Washington held slaves; and wherever you go up and down history, you find men, not angels." 71

While Phillips was enthusing in Plymouth, the Southern press continued to expand their Salem-based critique. The Richmond Examiner routinely criticized Massachusetts whose heritage of "Puritan bigotry is not relaxed in tension since...the hanging of defenseless and toothless old maidens for 'witchcraft'" simply for "opinion's sake."72 In an 1856 
article entitled "The War against the South," DeBow's Review's editor warned that the war between settler factions in Kansas and the assault on Charles Sumner in the Senate the previous spring no longer allowed Southerners to "beguile" themselves that abolition sentiment was confined to "a few fanatics." "73

The Kansas situation alerted those on both sides to the potential spread of violence. And in this context, abolitionist Parker Pillsbury in the late 1850s still carried on the somewhat limited, but spirited, tradition of attempting to turn the Salem witchcraft metaphor itself back onto the South. He did so in a Boston speech that connected the "barbarism of slavery" with a code that would in an earlier age be "willing to swing over the gibbet...every homely woman who dared to live a single life, and earn the reputation of being a witch. ${ }^{174}$ Wendell Phillips suggested in his speeches that the Puritans would have shipped guns to Kansas "in crates marked Bibles."75 While pro-slavery Judge LeCompte charged a Kansas grand jury to reject "conscience" as a defense by evoking "the early witchcraft history of Massachusetts, to prove the impropriety of being regulated by sincerity." 176

Similar sentiment was expressed by Governor Henry Wise of Virginia when he declined an invitation to attend the annual New England Society dinner in New York City in 1857. 
The Southern Literary Messenger was pleased to print his letter expressing his regrets accompanied by a gleeful annotation which praised wise for his ability to "draw in a few strong lines the character of the Pilgrim fathers more faithfully than the portraiture has ever been done."77 For Wise extolled Puritan virtues by saying that in all things their "consciences were on the Lord's side. They were against the devil and all his witches."78 In this way, Governor Wise took a jab at both the issue of conscience and the Puritan. Howell Cobb, a Georgia Congressman and author of "A Scriptural Examination of the institution of Slavery in the United States," summed up the opinion of many Southerners when he rejected the notion that Massachusetts freed slaves early in the seventeenth century out of virtue rather than convenience:

What a pity it was, however, that Massachusetts bestowed such an amount of sympathy upon Negroes, that when afterwards her own citizens (Quakers and witches), stood in need of it, it was all gone! It is so now. It is said, that at this time there are not many Quakers in Massachusetts, fewer witches, and plenty of abolitionists. Happy State! ${ }^{79}$

But it was John Brown's failed raid on the federal arsenal at Harpers Ferry, Virginia in October of 1859, and the presidential election of 1860 one year later that contributed a final burst of bellicose rhetoric tinged with cultural invocations of Salem. The ensuing flurry of reaction and commentary fully exposed not only the level of 
hate and fear that had developed with the sectional conflict but the profound ways in which Salem witchcraft had become intertwined in the expression of those emotions. Southerners who paid attention to such things probably expected no better of Wendell Phillips than to praise John Brown for the "brave act of an old Puritan soul" shortly after the Harpers Ferry raid. ${ }^{80}$ They were not prepared, however, for the general outpouring of approval in the North for the "spirit" of the raid if not the "act" itself. 81 The day after Brown's execution in Virginia, a North Carolina newspaper warned Virginia Governor Henry wise to burn the gallows lest some enterprising man remove it and ship it north as "Yankees have no objection to mingling money-making with their grief."82 The idea of memorial services and "mock funerals" rumored to be planned in the North irritated the same editor enough to suggest that if Northerners were looking for public entertainment, "it is a pity they haven't a witch or two to drown or burn."83 Daniel Hundley railed against the "Phillipses and Beechers [who] have spoken about John Brown...beating their drums ecclesiastic in a rage of fanatical zeal!"84 He for one no longer believed that when the old Puritans were "sorely exercised about Quakers, Baptists, and witches...they were not more befogged and befooled than are their descendants today."85 J.T. Wiswall imagined "swarms of transcendentalists" in New England 
cheering the impulse that drove "the Kansas gladiator, reeking with the blood of his murders" on to his actions in Virginia. For Wiswall, Brown's actions had their origins in the Northerners' Puritan legacy---an "inability to reason" that resulted in a "thousand kinds of fanaticism" and, of course, the "witch-burnings" that were only the first of these manifestations. ${ }^{86}$

Thus did Representative Abraham w. Venable, of North Carolina, who had complained in relation to the BedingerMann-Palfrey debate in 1849 that men could no longer speak on slavery without being labeled "agitators or fanatics," come full-circle by February 19, 1860. Angered by Horace Mann's comments on the floor of the House of Representatives condemning slavery the previous week, Venable lashed out at the "cant" and "mock sanctity" with which Mann spoke. "Let him blush when he speaks of the sins and crimes of any people on earth...no southern calendar of crime can afford such cases as the Salem murders. "88 But the mark of how much had changed in eleven years was not in Venable's assumption of Bedinger's 1849 charge against Mann but in the person who came forward to defend New England. It was not Horace Mann who took up the defense of Massachusetts but New York Republican Representative Charles Henry Van Wyck.

On March 7, 1860 Van Wyck made the first of two responses to Venable. Van Wyck charged that it was Southern 
Democrats not Northern Republicans who had been "preaching violence...[and] disunion. "89 Neither the Northern men nor the Republicans, he asserted, who "unchained the whirlwind of angry passion and bitter invective." 90 In regard to statements made on the floor on the $19^{\text {th }}$, Van Wyck continued, Venable "spoke of Massachusetts burning witches in the ancient times. Does he not know that your own people burn slaves at the stake, and it seems to awaken no horror in your minds?"91 This roused Reuben Davis of Mississippi to interrupt and call Van Wyck both "a liar and a scoundrel."92 Although Van Wyck said that Massachusetts had "able sons to defend her reputation," he returned on June 16, 1860 to the subject of Salem in response to Davis' objection. The "rebuke" to Massachusetts for "witch-burning some two hundred years ago" was instructive, Van wyck argued, as it provoked this compelling question: "how much more, then, are you chargeable with those of your own time?"93 He had no defense to make of the historical events in Salem. For the Republican position was that the "moral and political world...has its development" and that in that process there are always "despotisms and cruelties."94 But, if the Southerner wished to spread his "domestic and criminal arrangements...over the common territories," he should expect to answer for the abuses in the system of slavery 
which was so often defended in Congress as a "great missionary institution!"95

Historical references surfaced in several long articles in the leading Southern journals during the summer of 1860 that further detailed fundamental "racial" differences between white Americans of the North and South. Pro-slavery writers insisted that it was a fact that the "Puritan" was temperamentally "unfit for rational freedom... [which was] abundantly verified" both historically and in the current crisis. 96 The two sections were "deadly enemies, whose hatred no circumstance of time, place or even interest could soften." Just as "debates" in Congress had degenerated into speeches by men who no longer had faith in the ability to change one another's minds, the polarization and alienation between sections was reflected in the Southern press, as well. The journals of the South reacted to the rise of the Republican party, the Northern response to the Harpers Ferry raid, and the demise of a national Democratic party by finally abandoning their attempts to reach across sectional lines. "The Basis of Northern Hostility to the South" in DeBow's Review provided a catalogue of Northern cultural horrors and signaled that there was no longer even the pretense of believing that the preachers of abolition were "honest fanatics." Rather, there were only men who saw in the issue of slavery "a kind of adventitious 
opportunity."98 The motives of these men were simply the expression of historical and contemporary "envy and hate." Still, the author claimed, that he would have to leave it to the "leisured who study the human psyche" to determine what the exact cause was for Northern hatred. ${ }^{99}$ Even the Southern Literary Messenger, whose tone through the 1850s had been generally less inflammatory than DeBow's Review, hardened its position in the wake of Brown's raid and the advent of the Presidential election.

An unsigned article, "The Difference of Race between the Northern and Southern People," repeated the same cultural theme of spelling out fundamental difference between sections. It offered a history of sectional settlement that extended the old Puritan-Cavalier model further back in time to an Anglo-Saxon and Norman division. The more tribal, brutish Anglo-Saxons, the author explained, became the English faction who populated New England. Uncontrollable and even uncivilized in England, they "instinctively pursued the same path...squabbling, fighting, singing Psalms, burning witches, and talking about liberty" in the new world. ${ }^{100}$ This inability of Northerners to tame their natural "religious fanaticism" had political ramifications which endangered the more genteel Normandescended Southerner. Those who populated the South were "of royal pedigree" and were responsible for having established 
"law, order and government over the earth."101 Such claims were more than over-heated rhetoric and grandiose notions of lineage. They were part of an argument which insisted that Northerners enjoyed "liberty which they do not appreciate" that tended to run "into anarchy."102 In this manner, Southern observers warned about the potential consequences of a Republican victory and the establishment over the entire nation of a "Northern" government.

As the election loomed in the fall of 1860, the Boston based Atlantic Monthly ridiculed Southern fears. The South, it sneered, "seems to have become alarmed at its own scarecrow."103 And, perhaps to the Northern editor it had. But as the journals of the South continued to pour forth editorials and features that emphasized a "Northern mind and character" composed of the "fiercest, wildest elements," literate Southern citizens were bombarded with warnings that a most dire threat was on the horizon. And those fears did have a reasonable basis apart from the atmosphere generated by political rhetoric. A Republican administration posed a real threat to slavery despite the language of the Republican party platform. No one who had listened to William Seward or Charles Sumner over the last decade had any doubts about their power in the party or their goals for the disposition of the slavery question. ${ }^{104}$ By the time Southerners' worst fears were indeed fulfilled 
by the election of Republican Abraham Lincoln in November 1860, DeBow's Review would ask if it would not be "madness, worse than madness, servility and baseness, for the South to submit to a government which has passed into the hands of the fanatics of the North?" Such a question required little elaboration. ${ }^{105}$

The emotions that Avery Craven concluded were an essential pre-condition for armed conflict were thus now fully in place. Men did identify "their rivals with disliked and dishonorable symbols."106 As those symbols were largely of their own creation, they were able to invest them with traits not only antithetical to their own qualities, but with the utmost potency for generating hate and fear. Southern use of the metaphor of Salem witchcraft ensured that when a Southern citizen read about the recent election results in DeBow's Review in December of 1860 , he or she needed no further explanation of the message: "The North, who, having begun with burning witches, will end by burning us! "107

But, in the final months before the 1860 election there was another development that signaled that the Salem witchcraft metaphor had permanently entered American cultural discourse. That staunch bastion of abolitionism-the Boston based Atlantic Monthly, whose contributors and champions had done so much to refute the assignment of Salem 
witchcraft to their own cause and section - now used the event for their own purposes. In the same editorial that ridiculed Southern fears of a Republican victory, the Atlantic drew upon the Salem witchcraft metaphor itself in challenging recent Southern actions. The current "persecution" of free-state settlers in Texas over "pretended complicity" in a local arson plot, it argued, turned on evidence "obtained by means without a parallel since the trial of the Salem witches. "108

As the sectional crisis erupted into Civil War, more Northern newspapers and periodicals found utility in Saiem's metaphor. The Northern application of Salem during the war years paralieled that of the Southern rhetoric of the sectional crisis period. In both cases, Salem was used to marginalize what were perceived to be extreme political positions in the popular mind. This latest emergence of Salem witchcraft underscores the fact that while the metaphor had particular utility for Southern politicians and writers from 1849-60, its use expressed not so much tension over slavery, but a struggle to define the parameters of political power. 
Notes to Chapter Three

1. Congressional Globe, $30^{\text {th }}$ cong., $2^{\text {nd }}$ sess., 111-12. February 23, 1849. Horace Mann specifically complained of Bedinger's reference to Fisher's pamphlet which "has been profusely scattered about this House." Ibid., 318. February 26,1849 . The publication in question was the very popular pro-slavery polemic: Elwood Fisher, Lecture on the North and the South before the Young Men's Mercantile Library Association of Cincinnati, (Cincinnati, 1849). Fisher's lecture received wide distribution as a pamphlet, through lengthy reviews, and excerpting in the southern Quarterly Review 15 (July 1849):273-311; De Bow's Review 7 (August and October 1849): 134-45, 304-16. It also appeared again in 1857 in DeBow's Review 23 (August 1857): 194-201. Fisher, raised an anti-slavery Virginia Quaker had, for a time, practiced law in Cincinnati where he appears to have had a change of heart. The creation of a pro-Southern daily newspaper, the Southern Press in Washington, D.C., gave Elwood Fisher a wider audience as one of the two founding editors in 1850. See: Howard C. Perkins, "A Neglected Phase of the Movement for Southern Unity, 1847-1852," Journal of Southern History, 12, (May 1946):153-203. Perkins asserts that Fisher "popularized the selected-statistics method in the dialectics of the slavery controversy." Ibid., 165.

2. Ibid.

3. Ibid., 112.

4. On the abolitionists' construction of the slave-holder see: Craven, "Coming," 313; "Revolution the only Remedy for Slavery," (N.Y.: American Anti-Slavery Society,1855.) and, Ronald G. Walters, The Anti-slavery Appeal: American Abolitionism after 1830 (Baltimore: Johns Hopkins University Press, 1976.) 64-7.

5. Jan C. Dawson, "The Puritan and the Cavalier: The South's Perception of Contrasting Traditions," The Journal of Southern History 44 (November 1978): 599. See also: William R. Taylor, Cavalier and Yankee: The old South and American National Character (Garden City, N.Y.: George Braziller, 1963); Michael O'Brien, Rethinking the South: Essays in Intellectual History (Athens, Georgia: University of Georgia Press, 1993); W.J. Cash, The Mind of the South (N.Y.: Vintage, 1991); Frank Wesley Craven, The Legend of the Founding Fathers (Ithaca, N.Y.: Cornell University Press, 
1965); and, Michael Kammen, Mystic Chords of Memory: The Transformation of Tradition in American Culture (N.Y.: Vintage, 1993).

6 On the persistence of witch-burning as a symbol of "ignorance and barbarity" see: Bernard Rosenthal, Salem Story: Reading the Witch Trials of 1692 (Cambridge: Cambridge University Press, 1993), 209. See also: Rosenthal, Salem Story, 209. I argue that enters the "story" of Salem witchcraft at this time and in this manner.

7. Avery 0. Craven "The Coming of the War between the States 1860-65: An interpretation" Journal of Southern History, 2 (August 1936), 304. This is not to claim, however, that other issues did not contribute to the atmosphere of "cultivated hostilities." The "threat of amalgamation" or miscegenation (for instance) was mentioned constantly in debates and in written polemics. But, those were only considered a real threat as a result of the failure to stop the "fanatical abolitionist" from conquering the South. For an example of this cause and effect argument, see: Drayton, South Vindicated, 180. Those fears were also subsumed within the Salem witchcraft metaphor. Craven wrote in opposition to the "avoidable" conflict model of Civil War causation historiography. See especially: J.G. Randall, "The Blundering Generation," Mississippi Valley Historical Review 27 (June 1940): 4-16. On the sectional crisis politics in general, see: David M. Potter, The Impending Crisis, 18481861, completed and edited by Don E. Fehrenbacher. (N.Y.: Harper, 1976); William Ereehling, The Road to Disunion, 1776-1854 (N.Y.: Oxford, 1990); and Alan Nevins, Ordeal of the Union, 2 vols. (N.Y.: Charles Scribner's Sons, 1947).

8. Congressional Globe, $30^{\text {th }}$ cong., $2^{\text {nd }}$ sess., 112.

${ }^{9}$ John McCardell, The Idea of a Southern Nation: Southern Nationalists and Southern Nationalism, 1830-1860 (New York: W.W. Norton, 1979), 179. Southern emphasis in the antebellum period was on the development of tertiary institutions rather than on the development of those for primary and secondary education.

10 For a quantitative analysis and discussion of the use of northern authored schoolbooks in Southern academies, see: Rolla M. Tryon, The Social Sciences as School Subjects (New York: Ginn, 1935), and for a general overview of education in the nineteenth-century South, see: Edgar W. Knight, Public Education in the South (Boston: Ginn, 1922), 271. Knight says that northern authored books were used "out of 
necessity." Both studies confirm the perception of ante bellum editors when they voiced concerns about the cultural effects of the schoolbooks in use and the conclusions reached by Tryon about the national popularity of the authors listed in particular. For a study of Southern use of Northern publications including schoolbooks, see also: Jay Hubbell, The South in American Literature, 1607-1900 (Durham: Duke University Press, 1954), 354-66.

11 Drew Gilpin Faust, The Creation of Confederate Nationalism: Ideology and Identity in the Civil War South (Baton Rouge: Louisiana State University Press, 1988), 9-11.

12. Dawson, "Cavalier," 613. Dawson expanded on earlier studies of the various Yankee and Cavalier archetypes as sectional symbols found in the literary analyses of Rollin Osterweis and William R. Taylor, by analyzing the Southern use of the Puritan and Cavalier as symbolic figures in nonfiction sources. She delineated the use of the symbols in Southern periodical based social commentary designed specifically to foster a historically legitimate basis for the Southern "sense of itself as a conscious minority and its hostility toward the North." Dawson concluded that the archetypes of Puritan and Cavalier highlighted "the divided moral and religious heritage" of the two sections which, Southern social commentators asserted, resulted in the evolution of two radically different cultures within the United States. As Dawson's argument spans the general use from the early nineteenth through twentieth centuries her emphases and concerns diverge from my more specialized interest in a particular dimension of that use. For the mythology of the Virginia Cavalier and its adaptation as a Southern myth, see: Craven, Legend; and, Harlow W. Sheidley, Sectional Nationalism: Massachusetts Conservative Leaders and the Transformation of America, 1815-1836 (Boston: Northeastern University, 1998).

13 For a complete discussion of the schoolbook presentation of Salem witchcraft see Chapter One: Useful Knowledge. Also, for a sampling of Salem witchcraft described as specifically foreign in origin see the following: Morse, American Geography, 192; Adams, Abridgment, 105; S. Goodrich, First History, 37; and, Hinton, History, 71.

14. See: Avery 0. Craven, The Coming of the Civil War (Chicago: University of Chicago Press, 1957): Walters, AntiSlavery; and, Steven Mintz, Moralists and Modernizers:

America's Pre-Civil War Reformers (Baltimore: Johns Hopkins 
University Press, 1995).

15. William Drayton, The South Vindicated from the Treason and Fanaticism of the Northern Abolitionists (Philadelphia: H. Manly, 1836), quotes in order: 170, 161.

16. Ibid., 179.

17 Ibid. Italics mine. New Englanders were often described as "nasal" in speech.

18. "The New England Character," Southern Literary Messenger (hereafter: Southern Literary Messenger), 3 (July 1837), 412. In response to "Misconceptions of the New England Character," North American Review, 44(January 1837): 237-60.

19. Southern Literary Messenger, Character, 416.

20. Ibid.

21. "G.," "Thoughts and Reflections," Southern Literary Messenger 5 (October 1839), 707.

22. Review: "Religion in America," Southern Quarterly Review, 357.

23. Ibid., 358 .

24. Congressional Globe, $30^{\text {th }}$ cong., $2^{\text {nd }}$ sess., 161. February 26,1849 .

25. Ibid., 320 .

26. Ibid., 316.

27. "The Reform School of Massachusetts," The National Era 112, February 22, 1849, 30. This article was signed J.G.W. 28. Ibid. Giles Corey suffered such a fate at Salem.

29. "Slavery and Despotism," The National Era 126, May 31, $1849,87$.

30. Kinsley Scott Bingham, "Speech of Mr. Bingham of Michigan on the Admission of California. Delivered in the House of Representatives, June 4, 1850," the National Era, July 18, 1850, 116. For the full text of the speech see: Congressional Globe, $31^{\text {st }}$ cong., $1^{\text {st }}$ sess., 734 .

31. Ibid.

32. The first of the articles to mention Salem in the North 
Star "Salem Witchcraft \& Slavery in the District, \&c." was published on July 6, 1849 with the dateline "June 12, 1849, Washington" appeared, of course, following the National Era's spate of references but also began with a discussion of how recently "an editor of a Boston paper has favored his readers with long disquisitions on the subject."

33. "Biology-Moneyology-\&c," The North Star, October 29, 1849.

34. J[ohn] G[reenleaf] W[hittier], "Slavery in

Massachusetts," National Era 204 (November 28, 1850), 190. Whittier also claims incorrectly in this article that slavery never had "the sanction and authority of law" in Massachusetts but "crept into the Commonwealth like other evils and vices."

35. Ibid.

36."Calef in Boston, 1692," The National Era 142, September $20,1849,150$.

37. "The Edinburgh Review and the Southern States," DeBow's Review 10 (May 1851), 512. (hereafter: DeBow's Review)

38. "The Conspiracy of Fanaticism," United States Democratic Review (May 1850), 389-90.

39. The Democratic Review worried about the effect on the general population by a man who might "propound some stupendous dogma, to which he arrogates the sanction of Heaven, and they will batter down everything in its way." Ibid., 391.

40. Editorial, United States Democratic Review (July 1855), 82 .

41. Ibid., 83.

42. Ibid.

43. For a discussion of this in fiction and adult histories in the early republic, see: Philip Gould, "New England" 5882 .

44. Dr. Van Evne, "Slavery Extension," DeBow's Review 15 (July 1853), 1.

45. Ibid. 
46. Review: "Bancroft's History of the United States," DeBow's Review 15, 177.

47. Ibid., 180 .

48. Ibid., 181.

49. Ibid.

50. Robert Field Stockton, Letter of Commodore Stockton on the Slavery Question, (New York: S.W. Benedict, 1850) 20. Stockton was the commander of the naval forces which captured the southern California coastal cities in the Mexican-American War and first U.S. governor of the territory and so was assumed by many to have an informed interest on the question.

51. Moses Stuart, Conscience and the Constitution (Boston: Crocker and Brewster, 1850), 61. Rufus W. Clark said comparing the conscience of resisters to new fugitive slave laws with "that which the hangers of witches had" brings the whole concept on "conscience into contempt." See: Rufus W. Clark, A Review of the Revolution. Moses Stuart's Pamphlet on Slavery(Boston: C.C.P. Moody, 1850): 78 .

${ }^{52}$ Samuel F.B. Morse to Sidney Morse, December 29, 1857, reprinted in Edward Iind Morse, Samuel Morse Letters and Journals (1917), 2: 389-90.

53. Congressional Globe, $33^{\text {rd }}$ cong., $I^{\text {st }}$ sess., 1517.

54. Charles Sumner, Recent Speeches and Addresses, 1851-55 (Boston: Higgins and Bradley, 1856), 785. Sumner's own biographer notes Sumner's irritation with the earlier petition going to Edward Everett for submission to the Senate. Sumner did not feel Everett was as strongly committed to the cause. His biographer, Edward Lillie Pierce, dates Sumner's public notice from this debate. His performance, Pierce says, let Southern Senators know "they had a new kind of antagonist to deal with." See: Edward Iillie Pierce, Memoirs and Letters of Charles Sumner

(Boston: Roberts Brothers, 1877-94), v.3

55. Sumner, Recent Speeches, 786.

56. Ibid.

57. Congressional Globe, $33^{\text {rd }}$ cong., $1^{\text {st }}$ sess., 1555. I have yet to find aversion that carries the text this alleged 
"slur" but

Butler's remark that follows this in the debate can be read as alluding to something of the sort. This serves as an excellent example of the issue raised in the "Introduction" of the difficulty of recapturing oratorical references to Salem witchcraft even when the speech in question is purported to be published. We can't know if Butler was lying or if Sumner was exaggerating.

58. Ibid.

59. The best study of the New England Societies remains: Pershing Vartanian, "The Puritan as a Symbol in American Thought: A Study of the New England Societies, 1820-1920," (Ph.D. diss., University of Michigan, 1971).

60. Cephas and Eveline Brainerd (eds.), The New England Society Orations: Addresses, Sermons, and Poems Delivered before the New England Society in the City of New York, 1820-1885, 2 vols. (New York: New England Society of the City of New York by the DeVine Press), 193.

61. Ibid.

62. (Rev.) Charles B. Boynton, Oration Delivered before the New England Society of Cincinnati, on the Anniversary of the Landing of the Pilgrims, December 22d, 1847 (Cincinnati: Collins and Van Wagner, 1848), 20.

63. Ibid., 8 .

64.The 1820 meeting of the New England Society of the City of New York was marked by contention over the CongregationalUnitarian issue. Learning from this incident, the New York organization carefully avoided any topic that might split members' loyalties. As the sectional crisis intensified, this was increasingly impossible as the 1855 orations show. Ironically, although the Civil war led to the dissolution of many local NES organizations, Charleston, South Carolina navigated the political crisis to emerge as one of the strongest. See: Vartanian, New England Societies, 73-76.

65. Brainerd, New England Society, vol. 2, 74.

66. Oliver Wendell Holmes, M.D., Semi-Centennial Celebration of the New England Society in the City of New York December 1855 (New York: Wm. C. Bryant \& Co., Printers, 1856), 35. Although Holmes called slavery "the detested social arrangement of our neighbors" and found "manly logic" in abolition (Ibid., 38) if the situation ever called for a choice between alliance with the black or the white 
Southerner, Holmes said the "great family instinct... [would] settle the question for us." (Ibid., 43).

67. Sumner, Recent Speeches, 1851-55 (Boston: Higgins and Bradley), 390, 407. Sumner implied that the General Court also invalidated the laws against witchcraft in

Massachusetts Bay Colony. It did not. Further, in another of Sumner's many errors in this address, the actions he approximately describe were taken not by the General Court but by the predecessor of the current supreme Judicial Court which was the Superior Court of Judicature which was created specifically to oversee capital cases in the final days of the Salem investigations.

68. Ibid., 406.

69. Wendell Phillips, Speeches, Lectures, and Letters (Boston: James Redpath, 1863), 230.

70. Ibid., 236. Phillips made the very common error of conflating "Pilgrims" and "Puritans." Seldom did anyone distinguish between the two colonies and their inhabitants prior to 1870 and it was even common at the New England Society Dinners held annually in honor of the landing at Plymouth. For a fuller discussion of this issue and Salem witchcraft, see chapter six.

71. James Redpath, Echoes of Harpers Ferry (Boston: Thayer and Eldridge, 1860), 105. From an address originally delivered on December 19, 1859 at the Congregational Society, Boston, Massachusetts. Phillips also claimed that Brown acted out of the Puritan ethos of "action" both in Kansas and in Virginia.

72. "Duplicity better than Nationality, Richmond Examiner, April 24, 1855.

73. J.D.B. De Bow, "The War Against the South Opinions of Freesoilers and Abolitionists...," DeBow's Review 21 (September 1856), 272.

74. Parker Pillsbury, "West Indian Emancipation," The Liberator, August 12, 1859.

75. Phillips, Speeches, 231.

76. William Addison Phillips, The Conquest of Kansas(Boston: Philips, Sampson, and Company, 1856), 267-8.

77. "Editor's Table," Southern Literary Messenger 26 (January 
1858), 77 .

78. Ibid.

79. Howell Cobb, A Scriptural Examination of the Institution of Slavery in the United States; with its Objects and Purposes (Georgia: Howell Cobb, 1856), 114.

80. James Redpath, Echoes, 112. From an address originally delivered on December 19, 1859 at the Congregational Society, Boston, Massachusetts. Phillips also claimed that Brown acted out of the Puritan "ethos of action" both in Kansas and in Virginia.

81. Ibid., passim. For an example of this sentiment from a non-professional abolitionist, see also: Charles Henry Van Wyck, True Democracy--History Vindicated, (Washington, DC: Republican Executive Committee, 1860), 11. For an evaluation of both Northern and Southern responses to the raid, see: Paul Einkleman (ed.), His Soul goes Marching on: Responses to John Brown and the Harpers Ferry Raid (Charlottesville: University of Virginia Press, 1995).

82. (Raleigh, North Carolina) Register, December 3, 1859.

83. Ibid.

84. Daniel Robinson Hundley, Social Relations in our Southern States ( New York: H.B. Price, 1860), 16.

85. Ibid. Hundley also linked Salem witchcraft to "blue laws" and the "rejection of institutions" in various parts of this book.

86. J.T. Wiswall, "Delusions of Fanaticism," DeBow's Review 29 (July 1860), 46, 47. The root of such problems according to the author were the long New England winters which preyed on the mind and produced "hypochondria and querulousness" and there was also the troubling fact that in their colonies Awe find a large number of ministers." Ibid., 47 .

87. Congressional Globe, $30^{\text {th }}$ cong., $2^{\text {nd }}$ sess., 161. February $26,1849$.

88. Congressional Globe, $36^{\text {th }}$ cong., $1^{\text {st }}$ sess., 158. February 19. 1860 .

89. Van Wyck, True Democracy, 1. 
90. Ibid., 11.

91. Ibid., 12 .

92. Ibid.

93. "The Despotism of Slavery," delivered June 16, 1860 by Representative Charles Henry Van Wyck of New York in the House of Representatives of the United States. (Washington, DC: Republican Executive Committee, 1860); quotes from version: Congressional Globe, $36^{\text {th }}$ cong., $1^{\text {st }}$ sess., 434 .

94. Ibid., 435. Van Wyck was also angry that Davis had challenged him to a duel over the comments in March. The fact that Davis did so over "a mere utterance in a free country" was evidence Van Wyck claimed of the state of society in Mississippi due to the violent influence of slavery. Ibid.,435-7.

95. Ibid., 435, 436. Van Wyck advanced the Republican platform of 1860 position here in that he acknowledged that he "disclaim[ed] any right to interfere with slavery where it exists" but he did reserve the right to comment on what "deadens your own sensibilities and brutalizes your own people" referring both to the challenge to duel and to the several Southern newspaper excerpts he read into the record relating to mob violence against Blacks to support his argument in the earlier session.

96. A. Clarkson, "The Basis of Northern Hostility to the South," DeBow's Review 28 (July 1860), 9. This was shown by "the fierce fanatic intolerance of his opinions" on slavery.

97. Ibid., 7. Clarkson went so far as to advocate that the Mason-Dixon line be restored ---to separate the two fundamentally different white races.

98. Ibid., 8 .

99. Ibid.

100. "The Difference of Race between the Northern and Southern People," Southern Literary Messenger 30 (June 1860), 404 .

101. Ibid., 407 .

102. Ibid., 405 . 


\begin{abstract}
103. Ibid.
104. The editor of the Richmond (Virginia) Examiner certainly harbored no illusions: "The idle canvass prattle about Northern conservation may now be dismissed. A party founded on the single sentiment, the exclusive feeling of hatred to African slavery, is now the controlling power." November 9, 1860 .
\end{abstract}

105. Editorial Miscellany, DeBow's Review 29 (December 1860), 797. The "bloody shirts" of Harpers Ferry and Kansas were waved and the hated trio of Seward, Garrison and Sumner mentioned within this passage but there was no elaboration of the reference to witch-burning.

106. Craven, Coming, 304.

107. "Editorial Miscellany," DeBow's Review 29, 797.

108. "The Election in November," The Atlantic Monthly 6 (October 1860), 501 . 
CHAPTER FOUR

THE CULTURAL WORK OF SALEM WITCHCRAFT: FROM PURITAN TO PIIGRIM

In 1866, the English Pilgrim of Plymouth Colony made a second, albeit symbolic, migration to the shores of America. Benjamin Scott, an English Congregational minister delivering a historical oration before the Friends' Institute in London, insisted that to label the Pilgrim of Plymouth Colony a Puritan would be "unreasonable as it is unhistorical."1 In advancing his case for the "fundamental and irreconcilable"2 differences between the pioneering groups of English settlers, he considered at length the divergent origins and philosophies of the inhabitants of the New England's two early colonies. The seventeenthcentury Massachusetts Bay Colony Puritans, he argued, had their origins in a reformation movement within the Church of England. As such, their aims were to purify the State Church in their own image, to impose conformity, and to persecute" those who resisted. ${ }^{3}$ By contrast, the Pilgrim emerged out of John Robinson's separatist tradition. 
Robinson's influence provided the Pilgrims with both an impulse toward martyrdom and a truer congregational spirit. Wanting only to be left alone to perfect their relationship with God, they left others alone as well. There were no Quaker or witch hangings in Plymouth. The proof of their philosophy, Scott offered, was in the Pilgrims' willingness to shelter rather than persecute Massachusetts Bay Colony exiles. In providing such a refuge, the Pilgrim colony lived its principles and, thus, were the true "founders of religious and civil liberty in America."4

The idea that the Pilgrim was responsible for religious and civil liberty could easily be passed over as simply a moment of denominational chauvinism of the sort commonly advanced by ministers for a variety of reasons. In fact, another English minister, John Waddington, made a similar case in 1859, during the height of the sectional crisis, when Southerners routinely invoked the metaphor of Salem. During his successful tour of the United States, Waddington told his audiences at each stop: "The Puritans had half learned their lesson. The Pilgrims learned it all. They were not persecutors when in England or New England." 5 In 1859, however, most Americans seemed unconvinced 
despite the barrage of anti-Puritan Salem laden Southern rhetoric. Even the influential members of the New England Societies still insisted at their yearly dinner in honor of the Plymouth landing that there was no distinction between the Pilgrims and the Puritans. But by 1866 something had changed. In the aftermath of the Civil War, Americans gradually moved toward abandoning the now-tainted Puritan icon. The "discovery" of the Pilgrim solved an uncomfortable cultural problem by providing an alternative and non-controversial symbol of New England founding. Americans seemed eager to embrace the idea that there were two strands to the story of the nation's founding - one gentle and tolerant, one stern and coercive. Salem witchcraft proved decisive to an iconic transformation that turned Puritans into Pilgrims. The way in which this crucial shift in public opinion occurred reveals much about shifting cultural values. In particular, it reveals an increasing insistence that "toleration" was a defining American trait.

The shift has been overlooked by most twentiethcentury historians who have seen the growing late nineteenth-century emphasis on the Pilgrim as simply a 
refinement of familiar language employed to describe a national symbol. Two recent studies, Ann Uhry Abrams' The Pilgrims and Pocahontas: Rival Myths of American Origin (1999) and John Seelye's Memory's Nation: The Place of Plymouth Rock (1998) largely neglect the Puritan who populated nineteenth-century periodicals and schoolbooks. Both authors note that the New England symbols of Puritan and Pilgrim were regularly conflated, however, they attach little intellectual significance to the late nineteenth century decline of the Puritan. - Abrams argues that the Puritan in the 1850 s became a convenient repository for "unpleasant associations" and the Pilgrim for those considered "desirable." John Seelye maintains an equally rigid focus on the career of the Pilgrim symbol while noting that the orators of the 1820s "aspirated the Pilgrims and the Puritans in one breath. "I In addition, Seelye notes, "the prevalence of the Puritans," was assisted by their growing use in fiction. This "confounding" would last, Seelye admits, "more than a half century." 8 What neither considers, however, is that the Pilgrim was not merely rhetorically split-off from the Puritan, but instead supplanted him. This was done, as we 
will see, through a concerted effort to define the Plymouth Pilgrim in opposition to the Massachusetts Bay Colony Puritan. 9 This shifting use was a product of specific historical circumstances in the post-Civil war era.

As we have seen, the Salem metaphor first moved out of regional and limited use into the national imagination during public debates from the 1830 s onward over the validity of Spiritualism, Mormonism and a host of other religious and social movements. As David Brion Davis has observed, public controversies over the perceived subversive designs of certain nineteenth-century religious and fraternal organizations often led to a crisis point for critics whose values conflicted with their actions. While attacking the core beliefs of an organizations' members, antagonists demonstrated a constant desire to maintain their own claims to the central American cultural value of "toleration," even as they demonstrated intolerance. ${ }^{10}$ This paradox was, of course, solved within religious controversies by opponents casting the targeted sects as either not truly "religions" by American standards, or as having practices and structures so unorthodox and dangerously "foreign" as to forfeit any claim to religious 
toleration. Salem witchcraft thus became more than a useful metaphor to express the issues at stake in such battles. It illustrated as well the costs of deviance to followers and to the larger society. Salem surfaced again amid the political rhetoric of sectionalism among Southern writers and politicians in the 1850s, in a language and a tone that closely paralleled its use during the religious controversies.

During the Civil War, the invocation of Salem changed, as both Southerners, striving to build a sense of Confederate nationalism, and Northerners, intent on demonstrating their distaste for "radical" abolition ideology, made use of the metaphor. Such aims combined to confer a cultural meaning on Salem that persists to this day. The familiar terms of "fanaticism" and "delusion," long associated with Salem witchcraft, would appear with regularity in the 1860 s and beyond. Still bigotry or even persecution were terms that did not suddenly appear without precedent in the 1860s. Thomas Hutchinson's 1750 account of the Salem trials in his History of Massachusetts makes specific note of the issue: "I know not how to excuse the persecution," he admitted, "when the charter granted 
toleration to all Christians, except Papists."11 What is significant about this particular historical moment in the life of the Salem metaphor is that after decades of emphasis on the "fanatical" and "delusional," those would begin to be regularly paired with or replaced by words such as "tolerance" and "bigotry" until by the 1880 s Salem would be more associated with intolerance and persecution than with madness. Salem, that is, now appeared as an issue of power, rather than one public hysteria. Integrally bound up in this shift was the discovery that there was a fundamental "problem with the Puritan" - namely, an underlying tendency to "persecute" based in the Puritan's "intolerance" of dissent.

As Drew Gilpin Faust argues, such "symbols of political values" need to be taken seriously, for they played an important part in the construction of "Confederate nationalism." Despite the short life of the Confederacy, she observes, a fund of "Confederate words as well as deeds" delineated a national ideology and identity. ${ }^{12}$ Its sudden creation allowed the Confederacy little time for a considered cultural process of selfdefinition. Forced simultaneously to define itself as a 
nation and to define the United States as enemy, Confederate orators, politicians, polemicists, and editors engaged in the process of creating nationalism had to quickly establish a compelling ideology for their citizens. The most effective route was to elaborate themes that were already in place and widely used during the sectional crisis. ${ }^{13}$ In this way, Salem and the Puritans reappeared amid the burgeoning of Southern confederate nationalism.

For the Cavalier remained a central motif of the Southern, and now Confederate, identity. In the sectional crisis of the 1850s, the Cavalier had provided a useful counterpoint to the Northern "Puritan" as Southerners elaborated the merits of their region. The theme of distinctiveness likewise proved central in the early 1860 s to the emergence of Confederate identity. As the Richmond Enquirer observed in July 1861, "The Confederacy may pride itself, as making us a distinct people from the Yankee nation," in the absence of "that diabolical spirit of intolerance." 14 The Southern Literary Messenger found in the older associations of Salem with "delusions" and "fanaticism" a useful foundation for a claim of congenital intolerance among Northerners. The condition was a result 
of New England's colonization by

men of small minds, fanatical, and to a considerable extent, tinctured with insanity; this last feature has been the prolific source of the countless "isms" which have afflicted that region, and those settled by its descendants, from the days of witchism. ${ }^{15}$

Defining and inculcating a Confederate sense of national identity was, of course, a project that never fully came to maturity. We can see in it, however, the ways in which Salem remained a powerful element of nineteenth-century efforts to define a cuiturai mainstream.

Confederate writers recognized, for example, the importance of inculcating a new rendition of the nation's founding. One pamphleteer called for new Southern books for schools, as the current "Yankee story of the Puritans... is absolutely and entirely false. The current textbooks are nothing but the 'Puritan apotheosis.'"16 This South Carolinian expressed deep concern that the Confederate citizen was unaware of how extensive and insidious was the Northern invasion of Southern identity. He insisted:

For more than half a century, Southern apathy has permitted our country to be deluged with northern books and northern papers. Our schoolbooks, our histories, our journals, even our almanacs, have been printed, published by Northern men in Northern cities...by turning the vices and crimes of their forefathers into virtues and heroic actions. ${ }^{17}$ 
Northerner had, in essence, seduced the Southerner into a belief in a past full of error and deception. In the fall of 1861, the Southern Literary Messenger's editor also reminded readers that a complete southern literature was needed as "a nation cannot live upon bread alone."18

DeBow's Review endorsed the view that schoolbooks provided the fundamental building blocks for a new nation. J.W. Morgan noted, in "Our Schoolbooks," that "lessons learned in youth are formative and enduring. "19 Wise parents, he stressed, were selective about what their sons read. "The department of school books" was so completely dominated by Northern authors that many children were taught that their own fathers were "a heartless, cruel, bloody-minded set of robbers, kidnappers, and slaverywhippers."20 For The school book was where "Northern cunning and ingenuity had exercised its utmost power... as a most efficient mode of corrupting the minds of Southern youth."21 Morgan pleaded for any of the "men among us who are wellsuited to the work" to provide books that "Southern parents and teachers can with safety and good conscience place before their children." 22 In making the case for just how bad the situation was, Morgan stressed the schoolbooks were 
filled with praise and glorification of the first settlers of the New England and Northern States generally, as a set of incorruptible patriots, irreproachable moralists... on the other hand, the individuals, who organized society in the Southern States, are pictured as a race of immoral reprobates... [while] the institution of slavery... [is] made the occasion of much violent invective, there is but a slight effort at rebuke, and a large amount of apology is offered, for the amusements of burning witches... formerly so very popular in New England... such is the state of the histories. ${ }^{23}$

Although the exigencies of war and the brief life of the Confederate nation offered little opportunity for the fulfillment of these wishes, "R." or, "A South Carolinian" did answer the call for Southern books in 1864. The result, The Confederate, is a diatribe meant to reinforce patriotic sentiment. Throughout its one-hundred-odd pages, invective rains on the "the Yankee race, true descendants of their false and fanatical progenitors, the bigoted Pilgrim Fathers... [who] have caused the severance of that union between the States which can never be renewed." ${ }^{24}$ The author stressed his intention to deliberately, and interchangeably, "use the words, Puritan, Pilgrim Fathers, and Yankee in common... [as they] signify the same worthless crew. "25 By way of introduction, he invited the reader to "look a little into their antecedents and see what record they have left...written in the tears of their helpless and 
hapless victims. "26

The Confederate lingered over the history of Salem witchcraft. For its origins came from a time when, "at a loss how further to annoy and harass humanity, the Puritans happily fell upon the notable device of witchcraft."27 The discovery of witchcraft "afforded a glorious field for the display of Puritan intolerance, bigotry, malignity, and cruelty, and for a considerable time they flourished and luxuriated in it without stint or limit." ${ }^{28}$ No one else on this continent, "R" claimed, "ever burned witches."29 For this crime,

let these bigoted, fanatical, mischief-making, would-be enlighteners, instructors, exemplars, and reformers of the moral, political and religious world, be branded, like Cain for their crimes, and held up to the lasting scorn and derision of the world. ${ }^{30}$

The inclusion of Salem witchcraft in this 1864 publication was far from surprising. For the repeated use of "bigotry" as an adjective suggested that "tolerance" was fast becoming a value that could be further exalted by noting its absence in Salem.

Changes in the discussion of Salem in Northern print sources are even more revealing of a fundamental transformation that was reshaping the metaphor in Civil war 
America. In this instance, Salem provided a way of marginalizing elements of Northern society perceived as radical as well as unpopular governmental policies during the war years. Care must taken when criticizing either the government or abolitionists with close ties to the administration, of course, during wartime for a thin line separated criticism from treason. Still, Salem witchcraft remained a persistent metaphor in Northern print culture. Many who sympathized with abolition still thought that the radical varieties preached by the Sumners, Phillipses, Welds, or Garrisons were indeed "fanatical." Salem, in the current historical context, thus echoed its presence in earlier public debates about the anti-slavery movement. The vital issue in the critical Northern wartime rhetoric was not only the repetition and application of the witchcraft example as a provocative symbol of extremism, but also in the larger meaning associated with Salem. For the metaphor would be used easily to conjure up deeply held values.

In this context, tolerance also loomed large in the minds of Northern writers who reflected on the state of American society as the war clouds gathered. The New York Herald and the New York-based Harper's Monthly had brief 
but telling flirtations with the Salem metaphor. Between January 1861 and the firing on Ft. Sumter in South Carolina, both printed articles which attempted to rally public support for moderate or appeasing policies toward the seceded states from the Iincoln administration. With little time between the crisis and the on-set of war, the campaign was of extremely short duration. Yet, nonetheless, it is interesting in its adaptation of previously Southernbased images of the abolitionist as Puritan.

New York based Harper's Monthly had time for only one pointed reference to Salem witchcraft in the three months before war. In the March 1861 issue Harper's reminded readers that "Puritans... were a grim, gloomy, severe race of men."31 The idea that Puritans were "severe" would come as no news to any American reader in 1861. But the anonymous writer went on to advance a description of New England's founders using language that would largely displace detailed descriptions of Puritan "fanaticism"32 over the next two decades. Puritans, the editor said, would always "be more tenacious of their own views than tolerant of those of others; and the liberty they would defend at all hazards would be the liberty of thinking as they did." ${ }^{33}$ 
To the old defense that the Puritan was a product of his times, the author had a ready answer: "Our reply is that every sinner can be excused by the same plea... what are the times but people? And what are faulty times but tyrannical persons?"34 Yet despite his dismissal of the Puritan's own historical context, Harper's editor made a plea for his own place in his own cultural moment: "this whole matter seems to us only a hideous nightmare as we look at it in our lights of to-day." ${ }^{35}$ Thus he also relied on the old assumption that Salem witchcraft was a relict of an ignorant, unenlightened age. The ultimate result of the Puritan tenacity of opinion (and by implication that of the radical abolitionist) was "the shame of the witchcraft massacres." ${ }^{36}$ Curiously, the lesson drawn here from Salem, and for, presumably, the bloodless resolution of the current national political crisis, was "toleration." We must compromise on the Southerner's insistence on maintaining slavery, he advised, for to "respect the rights of others just as firmly as we insist upon our own, is the only path of peace." Obviously, the simple expedient of "toleration" for the slave-holders' viewpoint would avoid the "massacres" of Civil War. ${ }^{37}$ 
The New York the Herald, a daily, had more opportunity to work Salem witchcraft into its portrait of extremist New England abolitionists, allegedly driving Lincoln administrative policies in the first four months of 1861, than did Harper's. Indeed, the Herald began the year with a long two-part editorial entitled: "The Story of PuritanismReal Origin of Southern Secession." It promised to deliver the details on "the fierce controversy which has sprung from the propagandism of the Puritan sect of New England."38 There is, the editorial asserted with a pointed choice of terms, a long tradition of "glorifying New England and its Puritans at the expense of the rest of the people of the confederacy, and glossing over the indubitable facts of history which tell a very different tale." ${ }^{39}$ Reminding the reader that there was an argument for the Union being made up one of a "confederation of states," the pro-Southern, pro-slavery slant of James Bennett's editorial policy tried to remove the onus from the term that would within a month forme:lly name the organization of the seceding Southern states. The editorial described Massachusetts as a haven for "self complacent divines," "flattering orators," and "mutual admiration anniversaries," as well as home to 
"Plymouth Rock, the blarney stone of New England."40 As for philosophy, Massachusetts, with its Puritan past and present, possessed

one idea that penetrates and pervades them...that they have a right to regulate the whole political, moral and religious world, and that God has appointed them as supervisors over the conduct of their fellow men to control even their domestic affairs. ${ }^{41}$

The Herald presented an outlandish portrait of a Massachusetts devastated by the closing of the Atlantic slave trade. The state then turned "with a holy horror" on Southern slave holders "as they are intolerant of the prosperity which it gives the South. "42 Under the cover of abolition, the writer argued, Massachusetts' present day Puritans sought only power over others. Puritanism itself was part of a mentality that once had "claimed an exclusive patent from Heaven for religious persecution-a Divine right to do wrong."43 Indeed, the state was, the Herald concluded, the sole cause of secession. Its abolitionist activities constituted a fraud "on a par with their sincerity touching religious persecution in days of old...innocent men and women of the best character were put to death as witches by this intolerable fanatical despotism." 44

The Herald kept up this drumbeat on February 3, 1861, 
when it attacked both Henry Ward Beecher and Wendell Phillips for uttering words to the effect that within the Puritan tradition lies "the germ of which everything that is good in the country has sprung." It was typical of such "narrow minded Puritanism," the editor thundered, that Virginians Jefferson, Madison, and Washington were not mentioned. After invoking the Virginia trinity, he closed with a flourish by resurrecting Massachusetts' own contribution to American history and ideas: "It was not the witch burning, persecuting sectarianism of Massachusetts that modeled the constitution, but the liberal ideas of Virginia." ${ }^{45}$ Massachusetts, he averred, "has always arrogated too much credit to herself." 46

The Herald's late winter 1861 stance was in line with editor James Bennett's sentiments on the issue of slavery. The paper had opposed Lincoln's election and advocated compromise on slavery by confining it to below the MasonDixon line. Bennett and his staff never missed an opportunity to ridicule both the President and New England with a single evocative image. Since Iincoln had instituted a ban on liquor in the White House, it asked, did he realize that his high level staff was imbibing on a train 
trip? The Herald thought he might want this brought to his attention, "knowing as we do that the President is as prim a Puritan as ever sat under Cotton Mather preaching."147

James Crouthamel's study of Bennett and the Herald calls its position going into the secession crisis "prosouthern, proslavery, [and] anti-Republican." 48 Observers like George Templeton Strong, on hearing of the firing on Fort Sumter in April of 1861, cynically predicted an about face for Bennett and the Herald: "it takes naturally to eating dirt and its own words (the same thing)." 49 The very next day, as Lincoln called for volunteers to put down the uprising and regain sumter, the Herald decided that when the shooting started, the more vitriolic criticisms should end.

But the New York Herald did not undergo a complete "conversion" despite the advent of war or Iincoln's sending an intermediary to Bennett but rather because it was good for business. ${ }^{50}$ Still, occaisional small doses of the old vitriol surfaced. For example, New England and its abolitionists drew the Herald's ire and the longstanding Salem associated label of "fanaticism" for its "intrigues" and "machinations" in the fall of 1861. 
Laying the blame for the war itself and the "cry of mourning [which] will arise from untold bereft families" squarely at the door of New England abolitionists and their allies, it argued that it was only New England "fanaticism" that caused the South to be "goaded into overt acts of treason." 51

The newspaper did its part to goad the Lincoln administration when it felt that it was appeasing the "fanatical" Puritan faction and inveighed against the abolitionist "war of propagandism."52 In minor skirmishes in its pages from 1861 to 1865, the Herald continued its own war against the Massachusetts Puritan of the 1860s, even while it backed down from its initial pro-South position. Indeed, through its persistent use of the Puritan as the symbol of Massachusetts and abolitionism, and Salem witchcraft as the symbol for the Puritan, all joined in their "persecuting" spirit - the widely read New York daily helped establish the metaphor of Salem witchcraft as more than simply a regional slur within a specific crisis. In the pages of the Herald, Salem continued its career as a rhetorical device to express cultural limits. In its adoption of language that 
firmly and explicitly associated salem with persecution and intolerance the paper also participated in the evolution of the metaphor of Salem witchcraft and helped it become a national political metaphor.

That such rhetoric circulated widely was evident in the Presbyterian Philadelphia weekly, The Christian Recorder, one of many journals that reprinted a letter from an English reporter who had toured the South just after secession. William Howard Russell, who had reported on the Crimean War for the London Times, related that the South Carolinians detested "New England and the populations of the Northern States, whom they regard as tainted beyond cure with the venom of 'Puritanism'." South Carolinians informed Russell that,

The State of South Carolina was founded by gentlemen. It was not established by witch-burning Puritans, by cruel, persecuting fanatics, who implanted in the North the standard of Torquemada, and breathed into the nostrils of their newly-born colonies all the ferocity, blood-thirstiness, and rabid intolerance of the Inquisition. ${ }^{53}$

The vehemence with which such strongly worded opinions were stated clearly alarmed Russell. He maintained that it was difficult to preserve a "decent neutrality" when faced with their "violence." 
Obviously fanaticism and all the other provocative words long associated with Salem witchcraft and the Puritan still circulated freely on both sides of the Mason-Dixon line from 1861-65. But even C. Chancy Burr, whose newspaper The old Guard was a Copperhead catalogue of abolitionist inspired horrors, combined the new and old language of the Salem metaphor in 1861. "Intolerant fanaticism!" was Burr's evaluation of the Lincoln administration. Burr claimed he moved his office between New Jersey and New York severaI times to save himself from "Mr. Lincoln's dungeons and his reign of terror." He found ample interpretive power in the full range of words that over many decades had been associated with Salem. He raged that "Puritanism has always been a political religion."55 For men like Burr, intolerance, of necessity, required qualifiers to describe adequately why Massachusetts Bay Colony prescribed
drowning the Baptists, whipping the Quakers, boring holes through their tongues with red-hot irons, and driving women naked through the streets of Boston. All this because they would not adopt the Puritan sectarianism, [as] the Catholic 'slave'-holders of Maryland were laying the deep foundations of religious toleration and liberty. ${ }^{56}$

But in Burr's persistent assignment of "intolerance" to the North and his praise for the openness of Southern culture, he 
joined a chorus who emphasized the linkage between Salem and repression rather than Salem and delusion.

Criticism of what were perceived to be the radical elements of society was not, of course, confined to the established press. Individuals penned essays, poems, and treatises for private and public distribution that employed themes and language permeated with the now familiar illustration of Salem. To such writers, the extremist was a Puritan, Boston his home, fanaticism the well-spring of his ideas, and the persecution of others his goal. ${ }^{57}$ one enterprising journalist offered an erratically published newspaper entitled The Banner of Liberty that promised on its masthead to promote the Union and expose "Priestcraft." The newspaper, published in nine issues between 1848 and 1866, came out of Middletown, New York, but proximity to New England did little to dull its hostility to Massachusetts. Priestcraft, it claimed, was introduced into America by the Puritans, "whose narrow-brained and silly dogmas were enforced by...burning or drowning obnoxious persons under the pretense of the clergy and their dupes that they were witches!"58 Just when Puritanism had appeared to be finally dead, the anonymous editor wrote, what should 
occur but that "another generation should arise in place of that which had won liberty at such cost." 59 once in power, these ungrateful descendants obviously reverted to the Puritan type and celebrated the "triumph of fanaticism and ignorance in electing the nondescript Iincoln as President."

The theme of Puritan intolerance likewise informed discussion about prosecution of the war. It was amply apparent on the lecture circuit and in the press as Ohio Congressman Samuel Sullivan Cox carried on a vigorous campaign to expose what he termed "Puritan" treachery and treason. He filled a Broadway auditorium to standing-roomonly in January 1863 with a pointed assessment of the war effort, concluding that: "New England intolerant fanaticism made compromise impossible."60 A New York City audience estimated at 300 , and said to be of "the most intelligent and enthusiastic character," heard Cox inveigh against the "narrow, arrogant, selfish Puritan policy" in Washington. ${ }^{61}$ Abolition was clearly Cox's complaint, a grievance that appeared to be shared by the crowd of men in the hall. Cox called for a return to the 1861 "policy... which declared no war for conquest---no anti-slavery crusade." But, with "the 
bigots of New England" influencing policy, he saw no such hope on the horizon. As a "western man," Cox continued, he didn't intend to stand idly by as Puritanism, "the reptile which has been boring into the mound, which is the Constitution," destroyed the nation. It was, he said, "criminal nonsense" to expect that the Emancipation Proclamation would quell the rebellion. They were no more than "wild utterances of New England Puritanism, in press and pulpit" ${ }^{\prime 62}$

Some rose in defense of the Puritan. James Russell Lowell, who had turned away from radical abolitionism after John Brown's 1859 raid on Harpers' Ferry, claimed that the "delusion" of witchcraft had "nothing whatever to do with the Puritan." Lowell explained that witchcraft was a force in the world of the early New Englander, who had no alternative but to deal with its apparent outbreak. In an 1864 North American Review article, Lowell presented the Puritan as a vigorous man of business making hard choices in a hard world. As for the current preoccupation with the Puritan's lack of tolerance? "Toleration... is something which is won, not granted... [the Puritans] had no notion of tolerating mischief," Lowell 
stressed, making clear his own impatience with nonsense. ${ }^{63}$

It is striking that the New England Puritan and his specific crimes at Salem disappeared quickly from Southern rhetoric after Appomattox. Indeed Salem disappeared from widespread use even more rapidly than he had first arisen after the Congressional debates of 1849. Scattered references appeared occasionally but the focus now was on essential cultural differences and the potential for a nonspecific "Puritan" abuse of power in victory. George Fitzhugh, considering the "Impending Fate of the Country," gave the metaphor one of its final appearances in a major Southern periodical as he meditated on "history and experience... and the lessons which it[sic] teaches."64 Worried about the radical "rationalism" inherent in Northerners who had gainsd what history taught was always dangerous--"undue and prolonged ascendancy"-Fitzhugh suggested "looking to the blood" to find the likely future for the South. It was not a comforting image. Fitzhugh explained,

among the New England people (who rule the North with a rod of iron)... we find the former fanatics, radicals, and destructive by inheritance, just the same people now as ...the witch-burners and Quaker hangers two centuries ago...the Puritan fathers were 
sincere, earnest, conscientious men, but bigoted, fanatical, intolerant, narrow-minded, and cruel in the extreme. ${ }^{65}$

Surveying the post-war political landscape, from this vantage point, Fitzhugh predicted "civil war and military despotism." 166

Similar sentiment was evident in a report by Army veteran, former Freedman's Bureau official, and novelist J.W. DeForest who claimed to have spoken to an unnamed "Greenville planter." The gentleman assured DeForest that the war was not over slavery but "the aggressive spirit of the Northerners." DeForest's planter announced that the Puritans" "quarrelsome" natures Ied them not only to start the Civil war, but into other bloodletting ventures. They "got after the Indians and killed them by thousands, they drove out the Baptists and whipped the Quakers and hung the witches," the planter noted. ${ }^{67}$

Salem witchcraft still appeared in Southern journals in unusual ways in the late 1860s. John C. Delavique wrote about the prospects for continuing sugar and cotton cultivation without slave labor. Delavique complained of the "ruinous failure" facing the planter - a catastrophe rooted in the failure of Puritans and Pilgrims to "permit 
to others the toleration for the want of which they fled their country. They persecuted those who did not worship as they did, and burned witches." 68 In light of the war defeat, Delavique thought perhaps he would fare better in Brazil, away from Puritan "passions." 69

The Southern use of Salem, as well as that found in pro-Southern Northern sources during the war years, sheds some light on the emergence of this emphasis on tolerance as a definer of the Salem metaphor. The peace, and the needs of white reconciliation, however, intensified the association of Salem with tolerance. Moreover, it linked Salem witchcraft with the action that "intolerance" provokes-persecution. In this transformation, we can see why the Civil War became a liminal moment in the life of the metaphor. Urging "tolerance" for dissenting opinions euphemized the fight over the issue of slavery, and, more importantly, it dehumanized the issue. In John Delavique's plea for "tolerance" of those "who do not worship as they did, and burned witches," he implicitly asserted that only white owners paid the cost of slavery. In essence, in Delavique's comments and in similar uses, the conflict was defined as an abstract debate over "beliefs" between two 
white men, and thus re-defined the racialized project of national Reconstruction. ${ }^{70}$

According to Southern whites and their sympathizers, political Reconstruction required white reconciliation. The Southern incarnation of the old schoolbook icon, the Puritan, as the "demon" of the North in the sectional crisis and Civil War, and its subsequent appearance in the Northern press, completed a half-century's evolution of Salem as a symbol of backwardness, superstition, and fanaticism had started. It killed the Puritan as the primary symbol of founding and as the repository of American cultural virtues. Still, the Puritan symbol died neither a quick nor a completely uncontested death. Although the staunchest promoters of the Puritan were compelled to recognize that its rhetorical employment in the Civil War era had tainted the Puritan icon beyond any utility, they were able to transfer their allegiance. They did this in the decades following the war in the interests of the larger cultural goals of Reconstruction and, as well, to preserve their own regional centrality in the national narrative.

As was true during the sectional crisis, chapters of 
the New England Society (NES) in all regions of the United States remained deeply involved in an ongoing project to defend the Puritan as the founder of the nation and the fountain of all virtues. In 1838, when Salem and the Puritans were injected into both the Prophet Matthias scandal and the emerging anti-Mormon literature, Leonard Bacon reassured the New York NES that Puritan "prejudices and terrors" were appropriate to the seventeenth century. "Invective and ridicule" for believing in what was reasonable for the times, he continued, was unfair and insulting to such "venerable men."71 At many annual December dinners in many cities until 1860, speakers repeated the same sentiments. Thus Charles Boynton, at the 1847 Cincinnati annual dinner complained in frustration that the very mention of Salem in that day was "supposed to be the end of all controversy upon New England." If he thought of those words in 1860, he would have realized that it was only the beginning of the argument. ${ }^{72}$

The Civil War was an extremely difficult time for the New England Societies. The strongest group, in New York City, had an established membership, and an elevated status among the men's clubs; it weathered the storm out of sheer 
will despite New York's divisive conflicts during the war. Surprisingly, the Charleston, South Carolina chapter came out of the war intact and it grew stronger. It had long nurtured a genteel culture among its members, borne of mutual local interests and a vague fondness for ancestral connections in the North. During the early days of the secession crisis, members of Charleston's NES very quickly established their credentials as Southern men by suspending their annual dinner and donated time and money to Confederate charities and war drives. ${ }^{73}$ In the final years before secession, members such as Col. James Taylor complained at the annual dinner of currents of "wild fanaticism" promoted by "the pulpit and the press." 74 Unlike their Northern brothers, however, the Charleston speakers named neither Salem nor any specific issues raised about their forefathers. W.B. Carlisle in the 1860 NES Presidential address said only that: "whatever errors or evil has followed in the footprints of the Pilgrims or their misguided descendants, this great lesson is essentially and eternally American and knows no section or climate."75 But, the Pilgrims of Plymouth had neither "errors or evil" that anyone could trace, nor many widely 
recognized "misguided descendants" who might concern an 1860 Southern NES member. Carlisle's audience, long accustomed to the conscious unification of the Pilgrim and Puritan in their own organization's vocabulary, understood. In the diplomatic way that marked the Charleston NES, Carlisle was referring to the Massachusetts Bay Colony Puritan and his abolitionist descendants while avoiding the polemics of the tract or newspaper. That this mild a reference occurred at aII, and only once in the one hundred years of orations still extant, and that on the eve of secession, explains why Charleston, South Carolina's NES survived the war when many nationally did not.

After the war, the unofficial NES campaign to defend the Puritan was waged by the few remaining chapters with a mix of humorous, defensive, and sometimes odd attempts to rehabilitate the Puritan. The difficulty, as it had been since nearly the inception of their organization, was "Puritan fanaticism." 76 The St. Louis chapter in 1886 heard their President, James Richardson, refute Puritan "narrow mindedness." In response, George Leighton found instead much about the Puritan that "amuses" from "the high vantage ground of the nineteenth-century."77 In 1893 a Pennsylvania 
speaker, identified only as "President Smith," echoed Charles Boynton's 1847 remarks in Cincinnati: "When we make an unassailable position in politics or statesmanship, they say to us, 'Well, we, we quite don't know about you-you hanged the witches!" "But instead of the earnest and concurring response with which other speakers on the program greeted Boynton's remarks, Smith's provoked only "laughter" from the members. 78

Mark Twain's invitation to speak at the Philadelphia NES in December of 1881 must have represented the apotheosis of New England Society humor. Twain, who described his ancestry as Missouri "border-ruffian," (although he then was living in Connecticut) represented a departure from the usual minister, politician or businessman with familial ties to the region. ${ }^{79}$ He also diverged sharply in style and content. Rather than a celebratory oration about the New England past, Twain needled the membership about Puritan persecutions, among other skeletons. Claiming a Quaker ancestor whose heretical beliefs probably got her "to the same place which your ancestors went to, 180 he insisted New England imported slaves, while making reference to Roger Williams and the 
forebears who swindled Indians. Finally, Twain dug into the Salem episode with obvious gusto:

All those Salem witches were ancestors of mine! Your people made it tropical for them. Yes they did; by pressure and the gallows they made such a clean deal with them that there hasn't been a witch and hardly a halter in our family from that day to this. ${ }^{81}$

In his windup, Twain called on the society to disband and, ribbing the long held description of the witch hunt itself, to instead cease being "perpetuators of ancestral superstition." 82

But, by the 1880s, the day had arrived, in Philadelphia at least, when the Puritan could be incorporated into a narrative of progress. Local chapter President D.D. Wayland reflected in 1885 upon the recent dedication of a monument in Danvers, Massachusetts to convicted Salem witch Rebecca Nurse. He observed that "progress implies advance upon the past, implies that we were less wise yesterday than we are today. There is no progress without acknowledging and forsaking past errors." ${ }^{83}$ In responding, another member twitted what he called the "distinguished example of magnanimity for New England to hang a fellow and then two hundred years afterwards to erect a monument to him!"84 No one, Wayne MacVeagh assured Wayland, "has ever been hung in 
Pennsylvania for his religious opinions, or for his vagaries as to witchcraft... you have at last come to the home of civil and religious liberty." ${ }^{85}$ But former Governor of Massachusetts John D. Long's toast to close the evening's program contained a hint that explained the jocularity so newly apparent in Gilded Age NES speeches about Salem witchcraft.

Our Puritan forefathers are now aged men. They come out rarely---only once or twice a year...the Plymouth Pilgrim was...unlike the Puritan--a distinction which should never be forgotten--their religion was tolerant and large, never marred by persecution. ${ }^{86}$

Unlike Charles Boynton and the many other orators who insisted that a Pilgrim was a Puritan and that, Salem witchcraft notwithstanding, the two could not be divided, NES speakers by the 1880 s insisted upon the distinction. Twenty years after the Civil War, the New England Society had fully retreated from the Puritan as a primary symbol, largely because this progenitor was so deeply associated in popular imagination with intolerance and persecution. Instead, the Society now took organizational refuge in the symbol of the Pilgrim.

The rise of the Pilgrim in the post-Civil-War period addressed several cultural concerns in late nineteenth 
century America. A series of articles in periodicals inspired by Benjamin Scott's 1866 London oration on the Pilgrims, reflected the newly found power of Pilgrim iconography. Published in journals ranging from the Theological Review to Scribners Monthly, these essays traced the history of the Pilgrims in England and America, taking pains to carefully distinguish between the two. ${ }^{87}$

The attraction of the Pilgrim to late nineteenth century Americans rested, according to Wesley Frank Craven, on the symbol's ability to represent "the people themselves." "Have we not seen in them," Craven asked in 1954, "what we like to think we are---men of faith and men of courage, men who are free and men who are tolerant?"188 There was no need to defend the Pilgrim against charges of extremism. Best of all, the Pilgrim could be effectively promoted as the true "first" permanent settler. ${ }^{89}$ Michael Kammen attributes the promotion of the Pilgrim ideal to the plasticity that came with the relatively sparse public attention given heretofore to Plymouth Colony's founders in comparison to the Puritans. However, Abraham Iincoln's 1863 Proclamation establishing a national Thanksgiving holiday cemented the primacy of the Pilgrim in the American mind. 
By the last decades of the nineteenth century, Puritans had been recognized, Kammen notes, "as the mixed blessing that they in fact were." 90 Americans now wanted emblems of "intense faith, imagination, and courage" but not ones that evoked charges of being "intolerant." reconciliation and healing was equally strong and certainly an element, as mentioned, of wishing simply to make final peace after the Civil War. Instead, attacks against the symbols of the New England Puritan past became so common that, according to one New Englander: "all of our local historians are engaged in defending somebody." 92

Indeed as early as 1869, efforts to defend Puritans gave evidence that the tarnishing of New England's founders was well underway. In a review of Salem-related publications, William Frederick Poole sought to uphold the reputation of Cotton Mather, and he vociferously objected to accounts of Salem that were full of fanciful speculation and even character assassination. Most troubling to him was the fact that these erroneous and biased accounts "have obtained a lodgment in all the minor and school histories [sic]. .93

Poole also expressed distaste for the fact that 
witchcraft was "receiving more attention to-day than at any former period." As "the last great exhibition of a superstition," witchcraft demonstrated, much to Poole's chagrin, an extraordinary staying power. "Every incident," he complained, "connected with it has been preserved in the form of recorded, deposition, or narrative, imparts to it a peculiar interest, and one which will be permanent." 94 His remarks were not only prescient: they reflected the degree to which Salem's power as metaphor had become embedied in the national consciousness.

It was in this context, then, that the Pilgrim became for many Americans a welcome alternative. The Pilgrim seemed both less morally complex and less vulnerable to criticism than the Puritan. The Pilgrim permitted Americans to trace the foundational principles of religious and civil liberty back to the founding generation without the troublesome baggage of witch "burning" and intolerance.

Thus it was that the $250^{\text {th }}$ anniversary of the landing at Plymouth in 1870 offers us an unusually good moment to observe a cultural transition in the making, as the increasingly problematic Massachusetts Bay Colony Puritan 
gave way to the emerging symbol of the Plymouth Pilgrim. By witnessing and seizing that moment for a transformation of the Puritan icon, the nation could in yet another small way put the recent war to rest. The Puritan and Salem witchcraft remained as a constant reminder of the rancor of the sectional crisis and war and needed to be retired. Relocating the New England founder in Plymouth could achieve that end. The anniversary occurred, moreover, within a context that included a growing historical interest in Plymouth's founding--in short, an ideal time to make a smooth transition from Puritan to Pilgrim.

In December 1870, Ralph Waldo Emerson rendered his judgment on the Puritan in an address before New York's New England Society. Their history of persecution and intolerance, Emerson said, left the Puritan "more enamored with death than of life." "95 But Emerson found in the Pilgrim, who had of late been the beneficiary of "careful study," a worthy subject. Who best exemplified the nation's finest principles? "The Pilgrims, not the Puritans" for the Pilgrims "did not persecute."96 The 1870 anniversary celebration also found Robert $C$. Winthrop, scion of the founding Massachusetts Bay Colony Puritan family and long 
time New York NES leader, in Plymouth as an invited speaker. Winthrop, undoubtedly laboring under the double yoke of family loyalty and hoary NES traditions, refused to separate the two colonial symbols and resisted any effort to divide Puritans from Pilgrims. Yet Winthrop conjured up the specter of Salem, even if he did not speak of it directly. For his listeners would have quickly grasped Winthrop's reference to "the charges of intolerance, bigotry, superstition, and persecution, which there seems to have been a special delight in some quarters, of late years, in arraying against our New England Fathers and founders." These charges, Winthrop insisted, "apply without a doubt more directly to other Colonies than to that whose landing we this day commemorate." 97 Intentionally or not, in evoking the memory of the Bay Colony's founders, Winthrop himself lent support to the separation of the symbols as he tied his Puritan forbears to a legacy of "intolerance."

Certainly the celebration at Plymouth in 1870 vividly displayed what Ann Uhry Abrams has called the "old hairsplitting dispute over distinctions between Puritans and Pilgrims."98 Consider Edward Everett's contribution : We know the fun you love so well at Puritans 


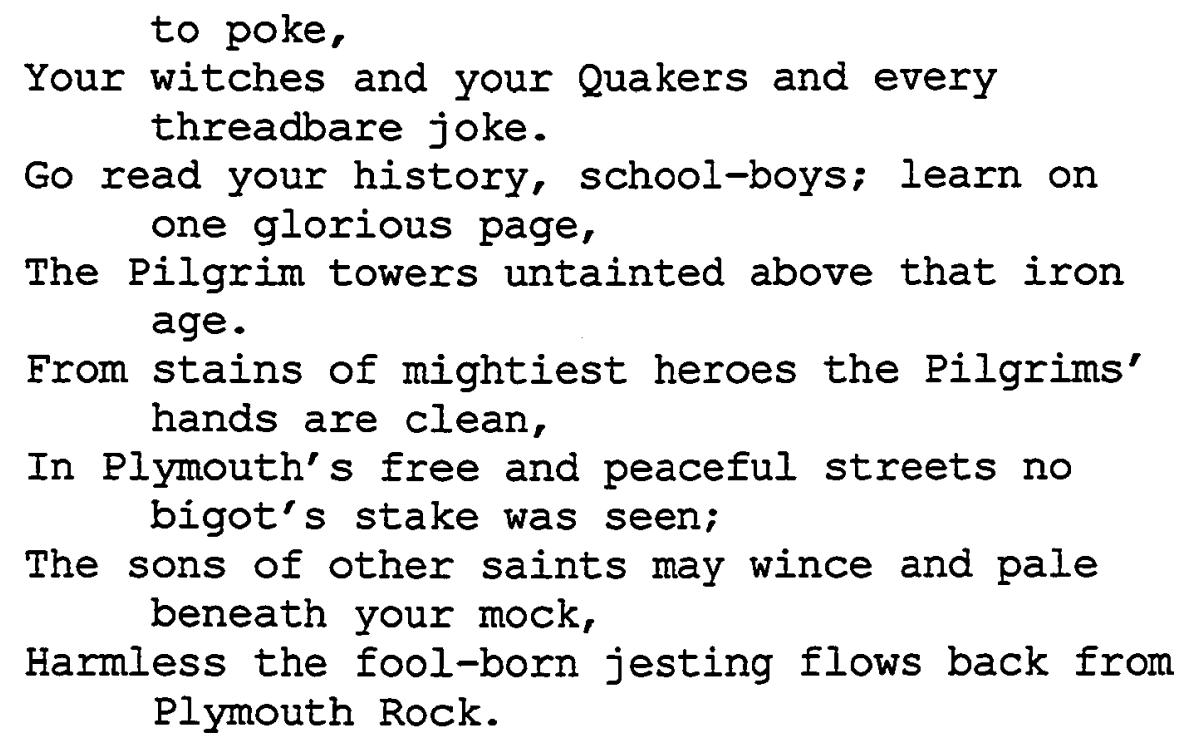

Although the very performance of such a poem at a Forefather's Day celebration marked, as Abrams observes, a "sea change in attitudes," it would be wrong simply to see Everett's poem as a "humorous dismissal" of the old issues. ${ }^{99}$ For the verse carried a message of history and of surrender. Undoubtedly, Everett's Plymouth audience found reason to "wince and pale" at what had been done in recent decades to local and national memory of the Puritan. Although given his due in the poem for surviving in an "iron age," the Puritan, nevertheless, was tainted by his nineteenth-century incarnation. In fact, even as Everett made reference to the Puritan as one of the "mightiest heroes," he admitted that his hands were "stained." By whose blood was clear in the poem. And, he had suffered his greatest rout through the continual invocation of Salem 
witchcraft, whose metaphorical life included false assertions that there had been victims burned at the "bigot's stake". Yet Everett sent another clear signal to his audience about the endurance of New England and its symbols. The Southerner came out of the Civil War with a comforting motto that claimed it could "rise again." Edward Everett in 1870 announced that, despite the brutal "foolborn jesting," New England, by transferring its allegiance to the Pilgrim, would ensure its continuing ascendance. 
Notes to Chapter Four

1 Benjamin Scott, The Pilgrim Fathers Neither Puritans nor Persecutors (London: Elliot Stock, 1891), 36.

2 Ibid., 18.

3 Ibid.

4 Ibid., 18, 21. Peter Gomes attributes this shift to "liberal historians" who were "forced to resort to a useful distinction which would provide them a set of respectable ancestors to whom they could attribute their own values." I argue that this is a broader cultural phenomenon arising out of particular historical circumstances. See: Peter Gomes, "Pilgrims and Puritans," 12.

5 John Waddington, Track of the Hidden Church, or The Springs of Pilgrim Movement (Boston: Congregational Board of Publications, 1863), xxiii-xxiv. For an evaluation of the same issues that Waddington mentions in relation to the Pilgrim as a desirable national icon, see: Craven, Legend, 86-101.

6 Ann Uhry Abrams, The Pilgrims and Pocahontas: Rival Myths of American Origins (Boulder, Colo.: Westview Press, 1999), 180. Abrams at various points in her book dates the separation of symbols to the 1840 s due to the UnitarianCongregationalist controversy and to 1870 when the $250^{\text {th }}$ anniversary of the landing at Plymouth produced what she calls a "sea change" in New England iconography.

'John Seelye, Memory's Nation: The Place of Plymouth Rock (Chapel Hill: University of North Carolina Press, 1998), 157.

8 Ibid.

9 For a forthright statement of this in an article which otherwise argues for a more prominent role for the Pilgrim symbol in nineteenth-century American culture, see: Peter Gomes, "Pilgrims and Puritans: 'Heroes' and 'Villains' in the Creation of the American Past," Proceedings of the Massachusetts Historical Society 95 (1983).

10 David Brion Davis, "Some Themes of Counter-Subversion: An 
Analysis of Anti-Masonic, Anti-Catholic, and Anti-Mormon Literature," The Mississippi Valley Historical Review 47 (September 1960), 224.

${ }^{11}$ Quotes in order: Thomas Hutchinson, The History of Massachusetts: from the first settlement thereof in 1628, until the year 1750. 2 vols. $3^{\text {rd }}$ edit. (Salem,

Massachusetts: Thomas C. Cushing, for Thomas and Andrews, Boston., 1795), 19, 30, 63, 19, 11 .

12 Drew Gilpin Faust, The Creation of Confederate Nationalism: Ideology and Identity in the Civil war South (Baton Rouge: Louisiana State University Press, 1988), 5. 13 Quote, Faust, 7.

14"The Catholic Church," Richmond (Virginia) Enquirer, May 29, 1863. see also: "The True Question: A contest for the Supremacy of Race, as between the Saxon Puritan of the North, and the Norman of the South," SLM 33, vol.1 (July 1861), 19 .

15 Jeffrey A., "European Emigration and New England Puritanism," Southern Literary Messenger 37 (August 1863), $100 . "$

16 A South Carolinian, The Confederate (Biloxi, Miss.: n.p., 1863), 10

17 Ibid., 10.

18 "Editorial," Southern Literary Messenger, 33 (October 1861), 353. See also: "Editorial," Southern Cultivator (November 1861), 291.

19 J.W. Morgan, "Our School Books," DBR 28, 436. 20 Ibid.

21 Ibid., 438.

22 Ibid., 440.

23 Ibid., 438

24 A South Carolinian, The Confederate, 3

25 Ibid., 15. 


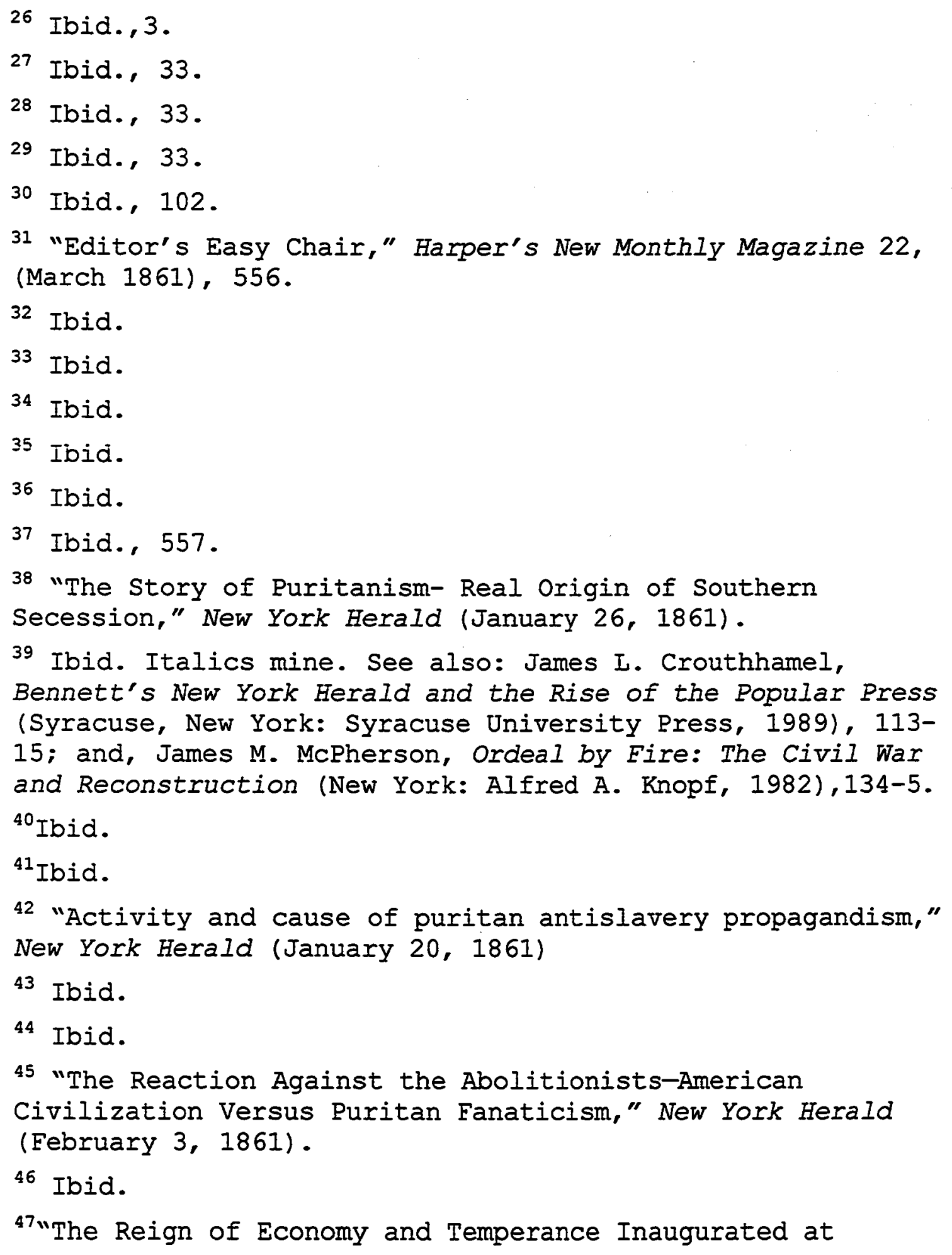


Washington," New York Herald (March 14, 1861).

48 Crouthamel, Bennett's New York Herald, 114.

49 Ibid., 116.

50 Ibid., 118.

51 Recruiting in Danger in the North from Secession

Sympathizers and Abolition Fanatics," New York Herald

September 28, 1861.

52 "Invasion of the South - The Inauguration of Civil War," New York Herald (April 8, 1861). See also: "The Fate of the Negro Decided," New York Herald (December 29, 1863).

${ }^{53}$ William Howard Russell, "What South Carolina Wants," The Christian Recorder (Philadelphia) (June 15, 1861).

${ }^{54}$ Ibid.

${ }^{55}$ [C. Chancy Burr], "Editorial," The Old Guard 1, vol. 1, 23. Burr regularly printed an engraving of New York's Democratic Governor Horatio Seymour who, while he briefly held office, was very critical of the war. By 1864, however, Seymour appears to have been judged by Burr as too moderate and had fallen out of favor. Burr may have picked up his terminology anywhere in the print world of 1861, but since he regularly appears to "compile" from the New York dailies including the Herald, their January articles might well have inspired him.

56"Civilization," 44.

${ }^{57}$ Among others, see: [Anon.], Puritania: A Satire (New York: Published by the Author, 1865); and Quevedo Redivicus, The South Church Council, (New Haven: n.p., 1863). Both use prominent abolitionists and politicians as well as passages that emphasize the Puritan "lack of tolerance to all who differed." Ibid.

${ }^{58}$ The Banner of Liberty (Middletown, New York: n.p., c. 1864).

${ }^{59}$ Ibid. 
${ }^{60}$ Samuel Sullivan Cox, Puritanism in Politics. Speech of Hon. S.S. Cox, of Ohio, before the Democratic Union Association, January 13, 1863 (New York: Van Evrie, Horton \& Co., 1863), 4 .

${ }^{61}$ Ibid.

${ }^{62}$ Ibid., 29.

${ }^{63}$ Quoted in Seelye, Memory's Nation, 453.

${ }^{64}$ George Fitzhugh, "The Impending Fate of the Country," DeBow's Review 2 (December 1866), 561.

${ }^{65}$ Ibid. , 568.

${ }^{66}$ Ibid., 569.

${ }^{67} \mathrm{~J} . \mathrm{W}$. DeForest, "Chivalrous and Semi-Chivalrous Southrons," Harper's Monthly 38, vol. 224 (January 1869), 199. It is possible that this is an apocryphal tale but attempts to identify it as such have failed. As noted in the text, DeForest was indeed situated to hear such an opinion immediately after the war. But, at the very least, it provides a glimpse of what a Northern writer believes a planter might after years of sectional rhetoric.

${ }^{68} \mathrm{John}$ C. Delavique, "Cotton Supply, Demand, Etc.," DeBow's Review 4 (December 1867), 569.

${ }^{69}$ Ibid.

${ }^{70}$ For a full discussion of this dimension of post-war attitudes and their long term consequences, see: David W. Blight, Race and Reunion: The Civil War in American Memory (Cambridge, Mass.: Harvard University Press, 2001). It also has a disturbing parallel to the anti-"political correctness" arguments that insist that statements having real and painful consequences for people should be simply considered "opinions."

${ }^{71}$ Brainerd, New England Society, 193.

${ }^{72}$ Boynton, New England Society of Cincinnati Annual Meeting December 22, 1847, 8.

${ }^{73}$ NESOC Charleston, 10-25. 
${ }^{74}$ Ibid., Col. James H. Taylor, 1858, 234.

${ }^{75}$ Ibid., 1860, 239.

${ }^{76}$ NESOC, St Louis, 1886, 10

${ }^{77}$ Ibid., 18.

${ }^{78}$ Thirteenth Annual Festival of the NESOC Pennsylvania at the Continental Hotel Philadelphia, December 22,

1893, (Philadelphia: New England Society), 27

${ }^{79}$ Mark Twain, The Complete Humorous Sketches and Tales of Mark Twain, Charles Neider (ed.), (New York: Da Capo, 1996), 493.

${ }^{80}$ Ibid.

${ }^{81}$ Ibid., 493.

${ }^{82}$ Ibid., 494.

${ }^{83}$ D.D. Wayland, NESOC Pennsylvania, Fifth Annual Festival, Dec 22, 1885 (Philadelphia: Times Printing House, 1885), 54.

${ }^{84}$ Hon. Wayne MacVeagh, NESOC Pennsylvania, Fifth Annual Festival, December 22, 1885 (Philadelphia: Times Printing House, 1885), 60.

${ }^{85}$ Ibid.

${ }^{86} \mathrm{~J}$ ohn D. Long, NESOC, Pennsylvania, Fifth Annual Festival, December 22, 1885 (Philadelphia: Times Printing House, 1885), 54 .

${ }^{87}$ Tryon Edwards, "Pilgrims and Puritans," Scribners' Monthly Magazine 12 (July 1876): 212-19;

${ }^{88}$ Craven, Legend, 101.

89 For a comprehensive examination of the Pilgrim in American culture, see: Seelye, Memory's Nation. Seelye argues that the Pilgrim was much more of a presence in American culture before 1880 than I do in this dissertation. I reached my conclusions based upon the visibility of the Plymouth Pilgrim (as distinguished from the combination symbol with a preponderance of traceable 
Puritan historical elements who is called one or the other) beyond the regional publications and orations prior to 1865. For a consideration of the various debates about the primacy of Jamestown and Plymouth as founding colonies and icons, see also: Abrams, The Pilgrims and Pocahontas.

${ }^{90}$ Kammen, Mystic, 211.

${ }^{91}$ Ibid., 211-13.

${ }^{92}$ Ibid., 214, 215

${ }^{93}$ William Frederick Poole, "Cotton Mather and Salem Witchcraft," North American Review 108 (April 1869), 337.

${ }^{94}$ Ibid. Among the books reviewed were Longfellow's New England Tragedies; Charles Upham's Salem Witchcraft; and, The Mather Papers, Vol. 8.

${ }^{95}$ New England Society of New York, 1870 Annual Festival (New York: Printed for the Society, 1870), 32.

${ }^{96}$ Ralph Waldo Emerson's address in Brainerd, New England Society, II:375. Emerson's oration clearly draws upon the 1866 Scott.

${ }^{97}$ Proceedings, $250^{\text {th }}$ Aanniversary, $86-7$.

${ }^{98}$ Abrams, The Pilgrims, 252. Abrams claims that at this moment Plymouth enters into emblematic status as a national rather than regional icon of patriotism. I do not disagree with her general chronology so much as her reading of the meaning and context of Everett's poem. This was clearly not a lighthearted change from the old "hair-splitting" arguments. The reading of all of the orations at Plymouth demonstrate that the surrender of the Puritan was done reluctantly even if by 1870 the "Puritan" was so damaged that their might have been an element of relief in the gesture.

${ }^{99}$ Ibid., 252. 
CONCLUSION

Almost twenty years before his symbolic surrender of the Puritan symbol at the Plymouth festivities of 1870 , Edward Everett told an audience at the New York Historical Society that "words written or spoken are at best but a kind of short-hand, to be filled up by the reader or hearer."I Everett's words are remarkably apt as a description of how Salem witchcrafit functioned as a culturaI metaphor. That an American reader or hearer would have a common understanding of the Salem metaphor is a function of the dissemination and persistence of the narrative of Salem witchcraft. That same nineteenth-century American, however, would be influenced by the ways in which the narrative was shaped before he received it. Exactly how that process occurred is complex and impossible to completely trace. We can, however, see some broad connections within such things as which version of contemporary narratives were selected by subsequent writers, the similarity of language used to describe the trials, and the early "choice" of Salem witchcraft as symbol. ${ }^{2}$ And, finally through this process, why the metaphor of Salem witchcraft became a critical element in the project of defining a national identity in the nineteenth century. 
In a privately circulated letter dated October 8, 1692, Puritan Minister Thomas Brattle carefully criticized the methods of the court trying accused witches at Salem. Within this critique, Brattle supplied his own narrative of the trials. In the letter he dismissed claims that mere glances by the accused could send anyone into "fitts." 3 Brattle said that some may call it the "Salem philosophy...but I think it rather deserves the name of Salem superstition and sorcery."4 Brattle worried about the judgment of "the reasonable part of the world ${ }^{s s}$ as they heard about the Salem trials. "They will laugh" he said "and conclude that the said S[alem] G[entlemen] are actually possessed, at least, with ignorance and folly."5 Brattle's words are intriguing. If, as Perry Miller argued in the 1950s, the Salem witchhunt "was intelligible to everybody concerned... within the logic of the covenant, " ${ }^{6}$ why not to this learned minister? And why do his words "superstition," "ignorance and folly," and his fear of the laughter of the "reasonable" sound somehow familiar? Aren't these nineteenth-century judgments reflecting nineteenth-century concerns? The answer is that they are. But they are also seventeenth-century judgments and the adoption of this contemporary language in later historical accounts may help explain why Salem witchcraft later became such an attractive historical subject and 
symbol.

The first history appeared immediately following the witchcraft trials. At the urging of the colony's Puritan ministers, and with the approval of the Governor sir William Phipps, Cotton Mather assembled an "official" narrative published in 1693 as, Wonders of the Invisible World. Within it, Mather laid out the theological rationale for the trials. These points were what Miller referred to when he said that the witch-hunt was "intelligible to everybody concerned." And, in a theological sense, within the New England Puritan tradition they were. The 1700 publication of Boston merchant Robert Calef's scathing counter-argument, More Wonders of the Invisible World, challenged Mather and the court as it drew upon a combination of dissenting opinions on Satan's agency in the world and the long standing doubts about "spectral evidence."7 But Calef's role in creating an alternative narrative of the trials did not rest upon his ability to engage Mather on the finer points of theology. Calef appealed to his contemporary audience and to those who later adopted him as their primary source because he challenged the trial's methods and motives. Five years (as it was actually written in 1697) had brought time for reflection, reconsideration, and not a little shame within the community. 
Indeed, Brattle's letter, which Calef referred to undoubtedly to expose ministerial doubts and for the authority of Brattle's position and learning, strengthened Calef's implicit argument that the ministers involved acted out of a sense of protecting their colleagues and the court in Salem. Calef also asserts and Brattle implies, that the officials concerned acted more through misguided enthusiasm or credulity than in rooting out the Devil in the Bay Colony. ${ }^{8}$ Calef himself used language throughout his book that is familiar from Brattle's letter but Calef went much further with his evaluation of the causes of the outbreak.

The Accusations of a parcel of possessed, distracted, or lying Wenches, accusing their Innocent Neighbours, pretending they see their Spectres... may have given them over to strong delusions to believe lyes, etc. And to let loose the Devils of Envy, Hatred, Pride, Cruelty, and Malice against each other; yet still disguised under the Mask of Zeal for God, and left them to the branding one another with the odious Name of Witch; and upon the Accusation of those above mentioned, Brother to Accuse and Prosecute Brother, Children their Parents, Pastors and Teachers their immediate Flock unto death; Shepherds becoming Wolves, Wise Men Infatuated; People hauled to Prisons, with a bloody noise pursuing to, and insulting over, the (true) Sufferers at Execution, while some are fleeing from that call'd Justice, Justice it self fleeing before such Accusations ... a Zeal governed by blindness and passion. ${ }^{9}$

Thus, by 1700 , much of the language with which Salem would much later be described was circulating in print by 1700. ${ }^{10}$ "Zeal," "infatuation," and "delusion" joined 
"superstition," "folly," and "ignorance" as part of the seventeenth-century lexicon of Salem witchcraft. These three narratives became the authoritative foundation, as contemporary chroniclers of the trials, for 300 years of argument about the catalysts for and conduct of them. ${ }^{11}$ The eighteenth-century English and American historians would prefer the more critical and more secular (and so, "rational") Calef over Mather's religiosity. Indeed, a survey of eighteenth-century general histories provides a preview of the words in which Salem witchcraft would persist in the American imagination. Several historians expressed outright hostility specifically toward Mather for his obvious belief in the phenomenon of witchcraft. Physician William Douglass whose 1749 history begs the reader to aliow him in his already "prolix introduction" to leave Mather's "amusements... [like] witches" to others. ${ }^{12}$ Douglass did comment upon the trials though and called them "horrid inhuman murder, by colour of law...perpetrated upon many ignorant maniacs, and other persons affected in their nerves and called witches." ${ }^{13}$ Jeremy Belknap, while writing his own 1784 History of New Hampshire told his friend Ebenezer Hazard that he wished Hazard was with him so that together they could laugh over Mather's Wonders of the Invisible World. Belknap marveled at 
Wonders in the letter: "What surprising power has nonsense over the minds of men, not only individuals, but collective, legislative, and judicial bodies!."14 Belknap summed up the trials themselves in his own history as something the Puritans did to "gratify their malignant humors."15

Daniel Neal, a Massachusetts Bay Colony Puritan historian writing while the trials were still in living memory, adapted his accounts of events in the history of the colony largely from Cotton Mather's own publications with one exception. Neal departed from Mather abruptiy on the issue of Salem. All the confessions and accusations, he wrote, "seem to me...the effects of a distemper'd brain."16 Mr. Salmon, whose 1738 treatment of New England history in his Iondon published History of the World obviously consulted Neal as he repeats that author verbatim while adding his own conclusion about salem minister Samuel Parris being "the prime author of the delusion."17 George Chalmers, a Loyalist who returned to England from America on the eve of the Revolution, called the witch-hunt "a kind of madness" perpetrated by a "credulous court" with the "greatest zeal and dispatch."18

Thomas Hutchinson though, as was discussed earlier in this thesis, stands as the most important eighteenth-century historian of Salem witchcraft in regard to American 
historiography. His consultation of earlier eighteenthcentury accounts is apparent as he took Douglass to task for blaming the town of Salem for regularly producing "hysterias" and "hypochondrias."19 His own notes refer not only to Douglass, but to Neal, Mather, Brattle, and Calef. To Hutchison, the participants in the accusations and trials were variously "credulous," guilty of "imposture or delusion," or, in such fear of being accused, fell under "bodily distempers."20

That these eighteenth-century historians influenced the next generation of histories in the early Republic to varying degrees has already been discussed. The words used about Salem also provide additional internal evidence that display the compilation techniques then in fashion. But to chose the same words, or, as in the case of Daniel Neal who agreed with Mather on all else but the Salem trials, the words have to express a personal judgment about the subject. The question then becomes, if eighteenth-century historians came to their own judgments about Salem framed within their own cultural or intellectual moment but also under the influence of the 1690 s narratives, how then did that pass into the wider consciousness?

A partial answer might lie within where Salem appears in eighteenth-century sources other than histories and who 
the authors of those references were. The first use of Salem as a historical example was, as might reasonably be expected, local. While still in living memory, Salem witchcraft had been evoked publicly in at least one public controversy. During the 1721-22 controversy over smallpox inoculation, a regular contributor to Boston's New England Courant, Nathaniel Gardner, wrote a parody of the dialogues published by Cotton Mather and other ministers supporting inoculation asking: "I pray, Sir, who have been instruments of Mischief and Trouble both in Church and State, from Witchcraft to Inoculation?"2I

But, by 1760 Salem witchcraft started to appear in other published and unpublished sources in (but at least once outside of) New England. Sporadically to be certain, and in ways that indicate it came to mind during crises as analogous to a contemporary issue and so foreshadowed its nineteenth-century metaphorical life.

One Philadelphia newspaper correspondent in the 1760s suggested that perhaps the installation of an American Bishop along the lines of the English church might be wise. His argument was made on the grounds that it might curb religious zeal as "who knows whether the New Englanders will remain content... and will not again hang Quakers [and] witches? ${ }^{22}$ As the letter was anonymous, or at least appears 
without an authorial designation, we can't know much about the background of the writer except that Philadelphia, as the largest colonial city and major center for intellectuals, publishers and booksellers, was likely to have any number of residents in 1768 who were capable of making such an historical analogy.

John Adams found Salem to be a useful analogy both publicly and privately in 1775. As "Novanglus", Adams wrote a series of letters in refuting the arguments of Loyalist Iawyer DanieI Leonard who as "Massachusettensis" wrote a series of public letters arguing for allegiance to the crown. Adams, referred to the "passivity" of Massachusetts Bay Colony in accepting a new charter in the 1690 s in spite of its "abridging English liberties." Such passivity, he claimed, had "less to be said in excuse for it than the witchcraft." 23 In a diary entry on the third anniversary of the Boston Massacre, Adams also invoked Salem as he reflected on his role as the defense attorney for the British soldiers calling it "one of the most gallant, generous, manly, and disinterested actions of my whole life." The conviction and execution of the soldiers, he continued, would "have been as foul a stain upon this country as the executions of the witches anciently."24 The following year, 1776, Alexander King, a Suffield, 
Connecticut physician, compared the tyranny of the local Committee of Safety to that of the Salem judges. He claimed that the climate in the Suffield area was such that any "inadvertant [sic] expression" might bring calamity to a household. Such a climate of public opinion, he said, reminded him of "the time of imaginary witchcraft at Salem." Then too men had neither "sense enough to perceive the impostures [nor] resolution enough to stem the torrent." 25

In these late eighteenth century appearances there is a common thread. Each of the references is made by a man who is either known to be well educated or, in the case of the Pennsylvania Gazette letter writer, can be assumed to be. By 1776, the only way in which anyone was likely to know about Salem was through the histories in print. When a particular contemporary situation produced a sense of anxiety or of a threat, it came to mind for at least a few men who left a written record of that fact. Political and social change would alter the situation. And, as we have seen in the early nineteenth-century democratization of education and print culture. The effect would be to increase that association and use dramatically.

The moment of transition or transformation can reasonably be located in one man, William Stone of the New York daily The Sun in 1835. Stone used Salem in an attempt 
to equate the enormity of Matthias" "imposture." This was in turn alluded to in New England Magazine, the North American Review, and Stone's own book on the scandal Matthias and His Impostures. ${ }^{26}$ Salem witchcraft, of course, by 1835 had widespread notoriety as the schoolbook exemplar of colonial "backwardness" and horror. This gave it a familiarity that undoubtedly assisted Salem's progress into the popular imagination. But, Stone gave the memory of Salem witchcraft one additional boost after Matthias' trial was adjourned. In 1839 (and once again under a different title in 1844) he used Salem witchcraft as the subject of a novel which used the themes and language of Thomas Brattle, Robert Calef, and all of their successors in the creation of a historical narrative of Salem witchcraft. The long forgotten newspaperman William Stone, perhaps more than anyone, performed the crucial role of propelling Salem into public controversies as a historical symbol.

What is telling about Stone's introduction of Salem into the Matthias scandal is its casual lack of detail. He assumed that his audience had enough familiarity with his historical allusion not only to recognize it, but to grasp the range of his objections to the actions and influence of Matthias. By raising the specter of Salem, Stone, like so many after him who would invoke the witchcraft outbreak as a 
metaphor amid other cultural controversies, was signaling that the Prophet Matthias operated outside of acceptable American religious practice. In fact, Salem proved so effective as a condemnatory illustration that other mainstream publications rapidly - and even avidly - adopted the symbol in their own commentary.

An imaginary past clearly played an important role in American cultural discourse during the early decades of the nineteenth century, when the project of nation-building sought symbols to bind citizens to the nation and to each other in an "imaginary community." 27 Historical symbols abounded in the histories and literature of the nineteenth century and, as Jane Tompkins has noted of popular fiction, they did cultural work by "proposing solutions." 28 As Americans sought not only a full definition of their new world and their own places in it, the past served as a frame of moral reference. When Salem was invoked to warn of the perceived dangers of excess present in religious innovations like Mormonism or to illustrate the allegedly evil incursion on Constitutional rights by abolitionists, it served as a warning that the tenuous connections of the "imagined community" were unraveling.

Indeed, just as positive nineteenth century symbols did "cultural work" by providing models from which to fashion 
the self and the community, negative symbols like Salem policed the boundaries of community. The event that Thomas Brattle feared would provoke the laughter of the "reasonable part of the world" in 1692 still remained, in language Brattle himself originated, a symbol of "ignorance and folly" in late nineteenth century America. The persistence of the memory of Salem witchcraft in American culture and its evolution into a persuasive metaphor of condemnation made another of Brattle's 1692 statements take on a prophetic ring: "I am afraid that the ages will not wear off that reproach and those stains which these things will leave behind them upon our land."29 
Notes to Conclusion

1 Edward Everett, The Discovery and Colonization of America, and Immigration to the United States, A Lecture Delivered before the New York Historical Society, in Metropolitan Hall, on the $1^{\text {st }}$ of June, 1853 (Boston: Little, Brown, and Company, 1853), $x$.

2 The Quaker executions in Massachusetts Bay Colony might be considered a "runner-up" in terms of mention in histories and other sources for both an example of Puritan oppression or as persecution. I have chosen not to discuss that here as it invariably, outside of sectarian disputes, appears only with Salem from 1692 through the nineteenth century. Many of the reasons for this are intertwined with the Quaker refusal to make an issue of the seventeenth-century execution of their co-religionists. The primary reason appears to be that the executions became part of the "martyrology" of the faith and so was better left unexamined for a variety of reasons. The best treatment of this subject can be found in : Carla Gardina Pestana, "The Quaker Executions as Myth and History," Journal of American History 80, vol. 2 (September 1993): 441-69.

3 Thomas Brattle, "Letter," October 8, 1692 in George Lincoln Burr, Narratives of the Witchcraft Cases, 1648-1706 (New York: Charles Scribner's Sons, 1914), 171.

4 Ibid., 172.

5 Ibid.

6 Perry Miller, The New England Mind: From Colony to Province (Cambridge, Mass.: Harvard University Press, 1956), 192.

7 For a discussion of how Calvinism was in the midst of a reconsideration of literal diabolical covenants and moving toward a view of Satan's influence being that of a tempter rather than as a real presence in the world, see especially: Ian Bostridge, Witchcraft and its Transformations, c1650c1750 (Oxford: Clarendon Press, 1997); G.J. Stronks, "The Significance of Balthasar Bekker's The Enchanted World, in Marijke Gijswijt-Hofstra and Willem Frijhoff, eds. Witchcraft in the Netherlands from the Fourteenth to the Twentieth Century, trans. Rachel J.J. van der Wilden-Fall (Rotterdam: Universitaire Pers, 1991); and Elizabeth S. Reis, Damned Women: Sinners and Witches in Puritan New 
England (Ithaca: Cornell University Press, 1997).

8 Robert Calef saw a multiplicity of factors influencing the trials. As in the passage following, he also believes that there was fraud by some of the witnesses. Particularly within the circle of the "lying Wenches."

9 Robert Calef, More Wonders of the Invisible World (Salem: Tilli isiul Carlton, 1700), 298-99.

10 For an informative discussion of the publication of Salem witchcraft related narratives in Massachusetts Bay Colony in the aftermath of the trials, see especially: Mary

Rhinelander McCarl, "Spreading the News of Satan's Malignity in Salem: Benjamin Harris, Printer and Publisher of the Witchcraft Narratives," Essex Institute Historical Collections 129, vol. 1 (January 1993): 39-61.

11 See: Cotton Mather, Wonders of the Invisible World (Iondion: John RusseII Smith, 1693); and Others in the Puritan community published their own accounts from 1693 to 1701. However those of Cotton Mather, Robert Calef and Thomas Brattle served as the most consulted and copied through the twentieth century. Other contemporary Puritan accounts include: Increase Mather, Cases of conscience concerning evil spirits personating men, witchcrafts, infallible proofs of guilt in such as are accused with that crime. : All considered according to the scriptures, history, experience, and the judgment of many learned men (Boston: Benjamin Harris, 1693); Matthew Hale, A modest enquiry into the nature of witchcraft and how persons guilty of that crime may be convicted: and the means used for their discovery discussed, both negatively and affirmatively, according to Scripture and experience (Printed by B. Green and $J$. Allen for Benjamin Eliot under the town house:1702); and, Joshua Scottow, A Narrative of the Planting of the Massachusetts Colony. (Benjamin Harris: Boston, 1694).

12 William Douglass, A summary, historical and political, of the first planting, progressive improvements, and present state of the British settlements in North-America (Boston: Printed and sold by Rogers and Fowle in Queen-Street., 1749), 364 .
13 Ibid., 449. (Douglass)
14 Jeremy Belknap Letter to Ebenezer Hazard, May 19, 1783, The Belknap Papers in Collections of the Massachusetts Historical Society, vol. 2, fifth series (Boston: Massachusetts Historical Society, 1877), 209. 
15 Jeremy Belknap, The History of New-Hampshire. : Volume I. Comprehending the events of one complete century from the discovery of the River Pascataqua. (Philadelphia: : Printed for the author by Robert Aitken, in Market Street, near the Coffee-House), 266.

16 Daniel Neal, Puritan, 44.

17 Mr. Salmon, Modern, 229.

18 George Chalmers, Continuation of Chalmers Politicâl Annals, Collections of the New York Historical Society for the year 1868 (New York: New York Historical Society, $1868), 110$.

19 Douglass, History, 448. Douglass' prime evidence of Salem's being a place that produces trouble, beyond the witch-hunt, was the prevalence of quaker converts in the area.

20 Hutchinson, History of Massachusetts, $19-38$ passim.

21 Mr. [Nathaniel] Gardner, "Another Dialogue between the Clergyman and Layman," New England Courant, January 22, 1722. According to Leo LeMay this article was one of three parodies of Mather's recently published: Sentiments on the Small Pox Inoculated, (Boston: S. Kneeland for Edwards, 1721).

Mather noted in his own diary about Gardner's several attacks: "Something must be done towards the Suppressing and Rebuking of those wicked Pamphlets, that are continually published among us, to lessen and blacken the Ministers, and poison the People." Cotton Mather, Diary, vol. 2:674.

22 Letter to the Editor, Pennsylvania Gazette, December 8, 1768 .

23 John Adams, "Novanglus; or, a History of the Dispute with America, from its Origin, in 1754, to the Present Time," in The Works of John Adams, Second President of the United States, Charles Francis Adams, (ed.) vol. 4 (Boston: Charles C. Little and James Brown, 1851), viii.

24 John Adams, Diary and Autobiography of John Adams, Iyman H. Butterfield editor, (Cambridge: Harvard University Press, 1961), entry for March 5, 1775. Adams also had connections in Salem and in 1766 notes in his diary that he had visited "Gallows Hill" when staying in the area specifically to see the historic site. See: Adams, Diary, Thursday August [7 or 14] and 1766 Wednesday August [6 or 13] 1766. 
${ }^{25}$ Journal of Alexander King (typescript), Connecticut Historical Society, Book N5, page 9, July 26, 1776.

${ }^{26}$ The Sun [New York], October 20, 1835; Stone, Matthias, 321; New England Magazine,409; and, North American Review, 324.

27 Benedict Anderson, Imagined Communities, rev. ed. (New York: Verso, 1996), 64 .

28 Jane Tompkins, Sensational Designs: The Cultural World of American Fiction (New York: Oxford University Press, 1985), xi.

29 Thomas Brattle, "Letter," October 8, 1692 in George Lincoln Burr, Narratives of the Witchcraft Cases, 1648-1706 (New York: Charles Scribner's Sons, 1914), 171. 


\section{BIBLIOGRAPHY}

\section{Manuscript Collections:}

Phillips Library, Peabody Essex Museum:

Nathaniel Hawthorne Papers

Special Collections, Yale University:

Morse Family Papers

Connecticut Historical Society:

Journal of Alexander King [typescript]

American Antiquarian Society:

Jacob Melyen Letterbook 1691-1696.

\section{Published Sources:}

A Citizen of Massachusetts [Charles Prentiss]. History of the United States of America. Keene, N.H.: John Prentiss, 1822 .

A South Carolinian. The Confederate (Biloxi, Miss.: n.p., 1863.

A., Jeffrey. "European Emigration and New England Puritanism." Southern Literary Messenger 37 (August 1863) : 463-72.

"Activity and Cause of Puritan Antislavery Propagandism." New York Herald. January 20, 1861.

Adams, Hannah. An Abridgement of The History of New England. For The Use of Young Persons. Boston: B. And J. Homans and John West, 1805

Adams, John. "Novanglus; or, a History of the Dispute with America from its Origin in 1754 to the Present Time" in The Works of John Adams, Second President of the United States. Charles Francis Adams (ed.) vol.4 Boston: Charles C. Little and James Brown, 1851. 
Adams, John. Diary and Autobiography of John Adams. Iyman H. Butterfield editor. Cambridge: Harvard University Press, 1961.

Adams, Rufus. The Young Gentleman and Lady's Explanatory Monitor. $2^{\text {nd }}$ ed. rev. and corr. Zanesville, Ohio: David Chambers, 1815.

Allen. "Credulity of The Times." Southern Literary Messenger. (June 1854): 343-44.

Anderson, John J. A. Pictorial School History of The United States; New York: Clark \& Maynard, 1864.

"Are The Phenomena of Spiritualism Supernatural?" New Englander And Yale Review. (May 1860) : 44-50.

Bancroft, George. A History of The United States. Boston: Charles Bowen, 1834.

Bancroft, George. History of The Colonization of The United States. The Present Abridgment. Adapted To The Young. In Two Volumes. II Boston: Charles C. Iittle And James Brown, 1841.

"Bancroft's History of the United States." (Review) DeBow's Review 15 (August 1853): 160-86.

Barber, John W. and Henry Howe. Our Whole Country; or, The Past and Present of the United States. Historical and Descriptive. 2 vols. New York: George E. Tuggle and Henry M'Cauley, 1861.

Barber, John Warner. Interesting Events In The History of The United States: Third Improved Edition. New Haven: Nathan Whiting, 1831.

Beard, George M. "The Delusions Of Clairvoyance. Scribners Monthly. (July 1879): 433-40.

Beard, George M. "The Psychology of Spiritism," North American Review 129 (July 1879): 65-81.

Belknap, Jeremy. The History of New Hampshire: Volume I: Comprehending the events of one complete century from the discovery of the River Pascataqua. Philadelphia: Printed for the author by Robert Aitken in Market Street near the Coffee House, 1790.

Belknap. Jeremy. Letter to Ebenezer Hazard. May 19. 1783. The Belknap Papers in Collections of the Massachusetts Historical Society. no. 2. fifth ser. Boston: Massachusetts Historical Society, 1877. 
Bell, J.D. "The Many and the Few," Ladies' Repository (September 1855): 525-28.

Berard, A[ugusta]. B[lanche]. School History of The United States. Philadelphia: H. Cowperthwait \& Co, 1855.

Bingham, Kinsley Scott. "Admission of California. $31^{\text {st }}$ cong., $1^{\text {st }}$ sess., July 18, 1850.

"Biology-Moneyology-\&c." North Star. October 29, 1849, 1.

Blake, J.I. (Rev.), A Geography for Children Boston: Richardson, Lord and Holbrook, 1831.

Boynton, Charles B. (Rev.). Oration Delivered before the New England Society of Cincinnati, on the Anniversary of the Landing of the Pilgrims, December $22^{\text {nd }} 1847$. Cincinnati: Collins and Van Wagner, 1848.

Brainerd, Cephas and Eveline (eds.). The New England Society Orations: Addresses, Sermons, and Poems Delivered before the New England Society in the City of New York, 1820-1885. 2 vols. New York: The Century Company, 1901.

Brattle, Thomas. "Letter of October 8, 1692," in George Iincoln Burr (ed). Narratives of the Witchcraft Cases, 1648-1706. New York: Charles Scribner's Sons, 1914.

Brigham, Amariah. Observations on the Influence of Religion upon the Health and Physical Welfare of Mankind. Boston: n.p., 1835.

[Burr, C. Chancy]. "Editorial." The Old Guard 1 . 1861.

Butler, Frederick. A Complete History of The United States Of America. Hartford: Printed For The Author, 1821.

By a Teacher, The Village School Geography. $3^{\text {rd }}$ ed. Hartford , Conn.: Reed and Barber, 1837.

Calef, Robert. More Wonders of the Invisible World. Salem, Mass.: William Carlton, 1700.

Campbell, Allan G. "Utah. Has It A Republican Form of Government?" The Century. (March 1882): 712-16.

"Carpenter's Mesmerism. Spiritualism. Etc." (Review) The North American Review. (September 1877):390-91.

Carter, Hendee, and Company. A List of Popular Elementary School Books. Boston: Tuttle and Weeks, 1832.

"The Catholic Church." Richmond (Virginia) Enquirer. May $29,1863$. 
Chalmers, George. Continuation of Chalmers Political Annals. Collections of the New York Historical Society for the year 1868. New York: New York Historical Society, 1868.

"Claims of Religion on The State." New Englander And Yale Review. (November 1854): 525-36.

Charles A. Goodrich (Rev.). A History of the United States of America. on a Plan Adapted to the Capacity of Youths. $35^{\text {th }}$ ed. Boston: Richardson, Iord, and Holbrook, 1832.

Clark, Rufus W. A Review of the Revolution. Moses Stuart's Pamphlet on Slavery. Boston: C.C.P. Moody, 1850.

Clarkson, A. "The Basis of Northern Hostility to the South." DeBow's Review (July 1860): 7-16.

Cobb, Howell. A Scriptural Examination of the Institution of Slavery in the United States; with its objects and Purposes. Atlanta: Howell Cobb, 1856.

Cobb, Lyman. Cobb's Juvenile Reader, 3; Containing Interesting. Historical. Moral. and Instructive Reading Lessons.....St. Clairsville, Ohio: Horton J. Howard, 1836.

"Comments on the Times." New England Magazine 7 (November 1834) : 407-13.

"A Convention of Spiritualists," Philadelphia Public Ledger, August 11, 1852.

"The Conspiracy of Fanaticism." United States Democratic Review (May 1850): 385-401.

Cox, Samuel Sullivan. Puritanism in Politics. Speech of Hon. S.S. Cox, of Ohio, before the Democratic Union Association, January 13, 1863. New York: Van Evrie, Horton, \& Co., 1863.

"A Credulous Place: Witchcraft, Spiritual Rappings, and Mormonism "The Living Age 58 (July 3, 1858):19.

"Curiosities of Puritan History: Witchcraft," Putnam's Monthly Magazine 2 (September 1853): 249-60.

De Leon, Edwin. "The Rise and Progress of the Mormon Faith and People," Southern Literary Messenger 10. (September 1844): 526-38. 
DeBow, J.D.B. "The War Against the South: Opinions of Freesoilers and Abolitionists..." DeBow's Review 21 (September 1856): 272 .

DeForest, J.w. "Chivalrous and Semi-Chivalrous Southrons," Harper's New Monthly Magazine 38 (January 1869): 192200.

Delavique, John C. "Cotton Supply, Demand, etc." DeBow's Review 4 (December 1867): 562-71.

"The Difference of Race between the Northern and Southern People." Southern Literary Messenger (June 1860): 40109.

"The Disembodied Spirits at Rochester," New York Herald, January 23, 1850.

"Disruption of the Federal Union," DeBow's Review 30 (April 1861): 432 .

"Duplicity better than Nationality," Richmond Examiner. April 24, 1855.

Douglass, William. A Summary. Historical And Political. Of The First Planting. Progressive Improvements. And Present State of The British Settlements In North America. Boston: Printed and sold by Rogers and Fowle in Queen Street, 1749.

Drake, Samuel G. The Witchcraft Delusion in New England. Vol.1. repr. New York: Burt Franklin, 1970.

Drake, W.E. The Prophet! A FuII and Accurate Report of the Judicial Proceedings in the Extraordinary and Highly Interesting Case of Matthews, alias Matthias. New York: n.p., 1835.

Drayton, William. The South Vindicated from the Treason and Fanaticism of the Northern Abolitionists. Philadelphia: H. Manly, 1836.

"The Edinburgh Review and the Southern States." DeBow's Review 10 (May 1851):512-25.

"Editor's Easy Chair," Harper's New Monthly Magazine 22 (March 1861):556-60.

"The Editor's Table." Southern Literary Messenger (January 1858): 75-9.

"Editor's Table." Southern Literary Messenger 33 (October 1861): 315-20.

"Editorial." Southern Cultivator. November 1861. 
"Editorial Miscellany." DeBow's Review 28 (December 1860) :739-42.

Edmunds, (Hon.) George F. "Political Aspects Of Mormonism." Harper's New Monthly Magazine. (January 1882) : 28588 .

Edwards, Tryon. "Pilgrims and Puritans." Scribner's Monthly Magazine 12 (July 1876): 212-19.

"The Election in November." Atlantic Monthly 6 (October 1860) : 492-503.

The Elements of Christian Science; $A$ Treatise Upon Moral Philosophy And Practice. Philadelphia: H. Hooker And Co. 1857.

Emerson, Joseph. Questions And Supplement To Goodrich's History of The United States. Boston: Richardson \& Lord. 1829.

Everett, Edward. The Discovery and Colonization of America, and Immigration to the United States, A Lecture Delivered before the New York Historical Society, in Metropolitan Hall, on the $1^{\text {st }}$ of June, 1853. Boston: Iittle, Brown, and Company, 1853.

"The Fate of the Negro Decided." New York Herald. December 29, 1863.

Eenning, Daniel. Universal spelling Book Or, A New And Easy Guide To The English Language. 28th Edition. Printed And Sold By Thomas B. Wait, 1786.

Field, Joseph. On Zeal. Boston: Gray And Bowen Printed For The American Unitarian Association, 1832.

Fisher, Elwood. Lecture on the North and the South before the Young Men's Mercantile Library Association of Cincinnati. Cincinnati: Young Men's Mercantile Library Association of Cincinnati, 1849.

Fitzhugh, George. "Moral Philosophies," DeBow's Review 3 (April-May 1867) :402-10.

----. "The Impending Fate of the Country." DeBow's Review 2 (December 1866): 561-70.

"Forthcoming Dramatic Novelty," United States and Democratic Review 32 (June 1853): 546-53.

G. "Thoughts and Reflections, Southern Literary Messenger 5 (October 1839): 706-07. 
"Ghosts In Our Foreign Policy" The Century. (March 1882): 778-79.

G[ilbert] Vale, Fanaticism; Its Source and Influence. Illustrated by the Simple Narrative of Isabella, in the Case of Matthias, Mr. And Mrs. B. Folger, Mr. Pierson, Mr. Mills, Catherine, Isabella, \&C., \&C. 2 vols. New York: G. Vale, 1835.

Gardner, Nathaniel. "Another Dialogue between the Clergyman and Layman." New England Courant (January 22. 1722)

Goodrich, Charles A. A History of the United States of America, accompanied by a book of questions and supplement by Reverend Joseph Emerson. $35^{\text {th }}$ ed. Boston: Richardson, Lord and Holbrook, 1829.

----. A History of The United States of America. Hartford: Huntington And Hopkins, 1823.

Goodrich, Samuel G. A Pictorial History of the United States. Philadelphia: E.H. Butler \& Co., 1865.

-----. Lights and Shadows of American History. Boston: Bradbury, Soden, and Co., 1844.

----. Peter Parley's Book of the United States, : geographical, political, and historical; : with comparative views of other countries. Rev. ed. Boston: Charles J. Hendee, and Jenks \& Palmer, 1841.

-----. Recollections of a Lifetime. New York: Sheldon and Company, 1864.

-----. The American Child's Pictorial History of The United States. J.H. Butler \& Co.,1879.

----- The First Book of History. : For Children And Youth. Cincinnati: C.D. Bradford \& Co., 1832.

----- The Tales of Peter Parley about America. $5^{\text {th }}$ ed. Boston: : Carter, Hendee, \& Babcock, 1831.

Goodwin. C.C. "The Mormon Situation." Harper's New Monthly Magazine. (October 1881): 756-63.

Greenwood, F.W.P. and G.B. Emerson. The Classical Reader: $A$ Selection of Lessons in Prose and Verse. From the most Esteemed English and American Writers. Intended for the use of the Higher Classes in Publick and Private Seminaries. Boston: Lincoln and Edmands, 1826.

Grimshaw, William. History of The United States. Philadelphia: J. Howe, 1824. 
Hale, John. "A Modest Enquiry into the Nature of Witchcraft," George I. Burr. Narratives of the Witchcraft Cases. 1648-1706. New York: Charles Scribner's Sons, 1914.

Hale, Matthew. A Modest Enquiry Into The Nature of Witchcraft And How Persons Guilty of That Crime May Be Convicted: And The Means Used For Their Discovery Discussed. Both Negatively And Affirmatively, According To Scripture And Experience. Printed by B. Green and J. Allen for Benjamin Eliot under the town house, 1702 .

Hale, Salma. History of The United States : From Their First Settlement As Colonies, To The Close of The War With Great Britain, In 1815. New York: Charles Wiley, 1825 .

Halyard, Harry [pseud.?]. The Haunted Bride: or, the Witch of Gallows Hill. A Romance of the Olden Time. Boston: F. Gleason's Publishing Hall, 1848 .

Hammond, William A. "The Physics and Physiology of Spiritualism," North American Review 110 (April 1870): 233-60.

Hartt, Rollin Lynde. "The Mormons." Atlantic Monithly. (Feb 1900) : 261-68.

[Hawks, Frances Lister] History of The United States: I. Or, Uncle Philip's Conversations With The Children. About Massachusetts. New York: Harper \& Brothers. 1835 .

Hawthorne, Nathaniel. "Main Street," in Twice Told Tales. Boston: Ticknor, Reed, and Fields, 1851.

Hawthorne, Nathaniel. The House of the Seven Gables New York: The Modern Library, 2001.

Hinton, John Howard. The History and Topography of the United States of North America, Brought Down from the Earliest Period. $2^{\text {nd }}$ ed. Boston: Samuel Walker, 1843.

"History of The United States" (Review). United States Democratic Review. (January 1850): 44-49.

Holmes, Abiel. The Annals of America, from the Discovery by Columbus in the Year 1492, to the Year 1826. Cambridge, Mass.: Hilliard and Brown, 1829.

Holmes, Oliver Wendell (Sr.). Semi-Centennial Celebration of the New England Society in the City of New York, 
December 1855. New York: Wm. C. Bryant \& Co., Printers, 1856.

Hooper, W.H. "Utah Statehood." $41^{\text {st }}$ cong., $2^{\text {nd }}$ sess., March 22 and 23, 1870.

Howe, E.D. History of Mormonism; or, A Faithful Account of that Singular Imposition and Delusion, with Sketches of the Characters of its Propagators. Painesville, Ohio: Published by the Author, 1840.

"Humbugs of the Day-The Rochester and Stratford Spirits Coming to Town," New York Herald, May 9, 1850.

Humphrey, E.J. [Mrs.] . "Glimpses of Heathendom." The Ladies Repository. (July 1865): 413-16.

Hutchison, Thomas. The History of Massachusetts: from the first settlement thereof in 1628. until the year 1750 . vol. 2, 3d ed. Salem. Mass.: Thomas C. Cushing. for Thomas and Andrews. Boston, 1795.

"Invasion of the South---The Inauguration of Civil War." New York Herald. April 3, 1861.

Jastrow, Joseph. "The Problems of 'Psychic Research," Harper's New Monthly Magazine 79 (June 1889): 76-82.

John Whiting. The History of North and South America. vol.1 London: n.p., 1776.

Lee, Eliza Buckminster. Delusion; or, The Witch of New England. Boston: Hilliard, Gray, and Company, 1840.

Charles G. Leland, "The Ash Tree," Continental Monthly 2 (December 1862):682-88.

Lieber, Francis. "Civil Liberty and Self-Government," Southern Quarterly Review 9 (April 1854): 300-33.

Iilly, Lambert [Frances Iister Hawks]. The History of New England. Philadelphia: William Hyde, 1831.

Long, John D. New England Society, Pennsylvania, Fifth Annual Festival, December 22, 1885. Philadelphia: Times Printing House, 1885.

Lossing, Benson. A grammar-school history of the United States: From the Discovery of America to the Present Time. New York: Sheldon and Company, 1869.

Mather, Cotton. Diary of Cotton Mather. Boston: Massachusetts Historical Society, 1870. 
-.---. Wonders of the Invisible World. London: John Russell Smith, 1693.

-----. Sentiments on the Small Pox Inoculated. Boston: S. Kneeland for Edwards, 1721.

Mather, Increase. Cases of Conscience Concerning Evil Spirits Personating Men, Witchcrafts, Infallible Proofs of Guilt In Such As Are Accused With. That Crime: All Considered According To The Scriptures, History, Experience, And The Judgment of Many Learned Men. Boston: Benjamin Harris, 1693.

[Matthews, Margaret]. Matthias. By His Wife. New York: n.p., 1835.

"Matthias and his Impostures (Review)," North American Review 41 (October 1835):307-27.

"Matthias and His Impostures," North American Review 89 (1835): 307-27.

M'Culloch. John. A Concise History of The United States. From The Discovery of America Till 1795: With $A$ Correct Map of The United States. Philadelphia: John M'Culloch, 1795.

Melyen, Jacob. "Letterbook, 1691-1696." American Antiquarian Society. July 11, 1692.

Memoirs of Matthias the Prophet, with a full exposure of his Atrocious Impositions, and of the degrading delusions of his followers New York: The New York Sun Press, 1835.

"Mesmer and Swedenborg," United States and Democratic Review 20 (February 1847):102-08.

Messerli, Jonathan. "The Columbian Complex: The Impulse to National Consolidation," History of Education Quarterly 7 (Winter 1967).

"Miracles And Their Counterfeits." Princeton Review. (April 1856): 255-85.

"Misconceptions of the New England Character," North American Review 44 (January 1837): 237-60.

S. Augustus Mitchell, A System of Modern Geography (Philadelphia: Thomas, Cowperthwait and Co., 1843

"Modern Necromancy." North American Review. (April 1855) $: 44-50$. 
Morgan, J.w. "Our School Books." DeBow's Review 28 (October 1860): $434-40$.

"The Mormon Theocracy." Scribners Monthly (July 1877): 39197.

"The Mormons in the Wilderness," North Star (Rochester), March 3, 1848.

"The Mormons." Southern Literary Messenger. (March 1851): 170-74.

Morse, Jedidiah. The American Geography. Elizabethtown, N.J.: Shepard Kollock, 1789.

Morse, Samuel F.B. "Samuel F.B. Morse to Sidney Morse, December 28, 1857." Samuel Morse Letters and Journals. Boston: Houghton-Mifflin, 1914.

Mr. Salmon. Modern History; Or. The Present State of AlI Nations. vol. 31 (London: n.p.. 1738), 305.

"A Nation's Right To Worship God." The Princeton Review. 31. no. 4 (Oct 1859) : 664-697

Nelson, T.A.R. "Polygamy in Utah." $36^{\text {th }}$ cong., $1^{\text {st }}$ sess., April 5, 1860.

"The New England Character," Southern Literary Messenger 3 (July 1837): 412-16.

New England Society of the City of New York, 1870 Annual Festival. New York: Printed for the Society, 1870.

Olney, J[ohn]. A History of the United States for the use of Schools and Academies. New Haven: Durrie and Peck, 1851 .

"On Somnambulism." The Living Age 63(October 1859):3-10.

Park, Benjamin. "Letter from New York," Southern Literary Messenger 16 (July 1850), 450.

Pestana, Carla Gardina. "The Quaker Executions as Myth and History," Journal of American History 80 (September 1993) : 441-69.

Phillips, Wendell. Speeches, Lectures, Letters. Boston: James Redpath, 1863.

Phillips, William Addison. The Conquest of Kansas. Boston: Philitips, Sampson, and Company, 1856.

Pierce, Edward Lillie. Memoirs and Letters of Charles Sumner. Vol. 3. Boston: Roberts Brothers, 1877-94. 
Pillsbury, Parker. "West Indian Emancipation." The Liberator. August 12, 1859.

Poole, Frederick William. "Cotton Mather and Salem Witchcraft." North American Review 108 (April 1869): 336-352.

Proceedings of the 250 th Anniversary. Plymouth, Mass.: Old Colony Club, 1870.

"The Professor At The Breakfast Table." The Atlantic Monthly. (May 1859): 609-20.

"The Progress And Disorganization." The American Whig Review. (July 1845): 80-90.

Puritania: A Satire. New York: Published by the Author, 1865.

George Payn Quackenbos, American History for Schools (New York: D. Appleton and Co., 1879

"The Reaction Against the Abolitionists---American Civilization versus Puritan Fanaticism." New York Herald. February 3, 1861.

"Recruiting in Danger in the North from Secession Sympathizers and Abolition Fanatics." New York Herald. September 28, 1861.

Redivicus, Quevedo. "The South Church Council." New Haven: n.p., 1863.

Redpath, James. Echoes of Harpers Ferry. Boston: Thayer and Eldridge, 1860.

Reese, David Meredith. Humbugs of New York: Being a Remonstrance against Popular Delusion. New York: John S. Taylor, 1838.

"The Reign of Economy and Temperance Inaugurated at Washington." New York Herald. March 14, 1861.

"Religion in America," (Review) Southern Quarterly Review 4 (April 1845): 350-72.

"Review of Tales of Peter Parley about America, Second Edition," in American Annals of Education 4 (MarchApril 1829).

"Revolution the only Remedy for Slavery." New York: American Anti-Slavery Society, 1855. 
Ridpath, John Clark. A Popular History of the United States of America, from the Aboriginal Times to the Present Day. Cincinnati: Jones Brothers and Co., C.1885.

"The Root of Our Present Evils." Catholic World. (May 1876) : 145-57.

Rush, Benjamin. "Of the Mode of Education Proper in a Republic," in Dagobart D. Runes, ed. The Selected Writings of Benjamin Rush. New York: Philosophical Library. 1947.

Russell, William Howard. "What South Carolina Wants." The Christian Recorder (Philadelphia). June 15, 1861.

"Salem Witchcraft \& Slavery in the District, \&c." North Star. July $6,1849,4$.

"Samuel Griswold Goodrich." Southern Literary Messenger. (October 1841): 736-39.

Scott, Benjamin. The Pilgrim Fathers Neither Puritans nor Persecutors. London: Elliot Stock, 1891.

Scottow, Joshua. A Narrative of the Planting of the Massachusetts Colony. Benjamin Harris: Boston, 1695.

"A Sermon on Witchcraft. J. L. Wilson" (Review) New Englander And Yale Review. (April 1846):297-98.

"The Shakers." Harper's New Monthly Magazine. (July 1857): 164-77.

"Slavery and Despotism," National Era. May 31, 1849, 87.

Stockton, Robert Field. Letter of Commodore Stockton on the Slavery Question. New York: S.W. Benedict, 1850.

Stone, William L. Matthias and His Impostures; or the Progress of Fanaticism. Illustrated in the Extraordinary Case of Robert Matthews, and Some of His Forerunners and Disciples. New York: The Sun Press, 1835.

----. Mercy Disborough (Bath, New York: R.I. Underhill, 1844 .

-----. The Witches: A Tale of New England Bath, New York: R.L. Underhill, 1837.

"The Story of Puritanism---Real Origin of Southern Secession." New York Herald. January 26, 1861.

Stuart, Moses. Conscience and the Constitution. Boston: Crocker and Brewster, 1850. 
Sumner, Charles. Recent Speeches and Addresses, 1851-55. Boston: Higgins and Bradley, 1856.

The Banner of Liberty. Middletown, N.Y.: n.p., C.1864.

The Fourth Class Book: Containing Lessons in Reading, for the Younger Classes in Schools. $2^{\text {nd }}$ ed. Brookfield, Mass.: E.\& G. Merriam, 1828.

Thirteenth Annual Festival of the New England Society of Pennsylvania at the Continental Hotel Philadelphia, December 22, 1893. Philadelphia: New England Society, 1894 .

Thomas Hutchinson. The History of Massachusetts: From The First Settlement Thereof In 1628, Until The Year 1750. 2 vols. $3^{\text {rd }}$ edit. Salem. Mass.: Thomas C. Cushing. for Thomas and Andrews, Boston, 1795

Thomson. "Witchcraft" The Ladies Repository. (March 1846): $69-72$.

"To Diamonion, Or The Spiritual Medium" The National Era. December 9, 1852, 200.

Tower, David B. and Cornelius Walker. North American Second Class Reader (Boston: Benjamin B. Mussey \& Co., 1849.

"The True Question: A Contest for the Supremacy of Race, as between the Saxon Puritan of the North, and the Norman of the South." Southern Literary Messenger 33 (July 1861): 19-27.

"The Two Prophets of Mormonism." Catholic World. (Nov 1877) : 227-49.

Twain, Mark [Samuel Clements]. The Complete Humorous Sketches and Tales of Mark Twain. Charles Neider (ed.) New York: Da Capo, 1996.

Van Evne, Dr. "Slavery Extension." DeBow's Review 15 (July 1853) : 1-14.

Van Wyck, Charles. True Democracy---History Vindicated. Washington, D.C.: Republican Executive Committee, 1860 .

Waddington, John. Track of the Hidden Church, or The Springs of Pilgrim Movement. Boston: Congregational Board of Publications, 1863.

Wayland, D.D. New England Society Pennsylvania, Fifth Annual Festival, December 22, 1885. Philadelphia: Times Printing House, 1885. 
Webster, Noah. An American selection of lessons in reading and speaking: calculated to improve the minds and refine the taste of youth, and also to instruct them in the geography, history and politics of the United States : to which is prefixed, rules in elocution and directions for expressing the principal passions of the mind : being the third part of $A$ grammatical institute of the English language : to which is added an appendix containing several new dialogues. Boston: Isaiah Thomas and Ebenezer T. Andrews, 1787.

Whittier, John Greenleaf. "Calef in Boston." National Era. September 20, 1849, 150.

W[hittier], J[ohn] G[reenleaf] . "Slavery in Massachusetts." National Era. November 28, 1850, 190.

----. "The Reform School of Massachusetts," National Era. Eebruary 22, 1849, 30.

Willard, Emma. History of The United States, Or, Republic

Of America. New York: White, Gallagher \& White, 1828.

Willson, Marcius. "Review of American Common School Histories," The Biblical Repository and Classical Review. $3^{\text {rd }}$ ser. (July 1845), 505-517.

Worcester, Joseph. Questions and Supplement to Goodrich's History of the United States. Boston: Richardson and Lord, 1829.

Yeomans, John. "Address delivered in Easton. Pennsylvania, August $18^{\text {th }} 1841$, on the Occasion of the Author's Inauguration as President of Lafayette College." The Princeton Review 14 (June 1842):203-218.

Young, Eugene. "Revival of The Mormon Problem" North American Review. (April 1899): 476-90.

\section{Secondary Studies:}

Abrams, Ann Uhry. The Pilgrims and Pocahontas: Rival Myths of American Origin. Boulder, Colo.: Westview, 1999.

Abzug, Robert H. Cosmos Crumbling: American Reform and the Religious Imagination. New York: Oxford University Press, 1994. 
American National Biography. 1999 ed. "Samuel Griswold Goodrich," by Robert I. Gale.

Anderson, Benedict. Imagined Communities: Reflections on the Origin and Spread of Nationalism. New York: Verso, 1983.

Arvin, Newton. Hawthorne. New York: Russell \& Russell, 1956.

Blight, David w. Race and Reunion: The Civil War in American Memory. Cambridge, Mass.: Harvard University Press, 2001.

Bostridge, Ian. Witchcraft and its Transformations. c1650c1750. Oxford: Clarendon Press, 1997.

Boyer, Paul S. and Stephen Nissenbaum. Salem Possessed: The Social Origins of Witchcraft. Cambridge. Mass.: Harvard University Press, 1974.

Braude, Ann. Radical Spirits: Spiritualism and Women's Rights in Nineteenth-Century America. Boston: Beacon Press, 1989.

Buell, Lawrence. New England Literary Culture: From Revolution through Renaissance. New York: Cambridge University Press, 1986.

Bushman, Richard I. Joseph Smith and the Beginnings of Mormonism. Uroana: University of Illinois Press, 1985.

Butler, Jon. Awash in a Sea of Faith: Christianizing the America People. Cambridge, Mass.: Harvard University Press, 1990.

Calhoun, Daniel. "Eyes for the Jacksonian World: William C. Woodbridge and Emma Willard," in The Journal of the Early Republic 4 (Spring 1984).

Carpenter, Charles. History of American Schoolbooks. Philadelphia: University of Pennsylvania, 1963.

Carroll, Bret E. Spiritualism in Antebellum America. Bloomington, Indiana: Indiana University press, 1997.

Cash, W.J. The Mind of the South New York: Vintage, 1991.

Charles F. Heartman. The New England Primer...a Bibliographical Checklist. Metuchen, N.J.: Charles F. Heartman, 1922.

Clark, Jr., James William. "The Tradition of Salem Witchcraft In American Literature: 1820-1870"(Ph.D. diss.. Duke University). 
Cohen, Patricia Cline. The Murder of Helen Jewett: The Life and Death of a Prostitute in Nineteenth-Century New York. New York: Alfred A. Knopf, 1998.

Colacurcio, Michael. The Province of Piety: Moral History in Hawthorne's Early Tales. Cambridge. Mass.: Harvard University Press, 1984.

Craven, Avery O. "The Coming of the War between the States, 1860-65: An Interpretation," Journal of Southern History 2 (August 1936):303-22.

Craven, Avery 0. The Coming of the Civil War. Chicago: University of Chicago Press, 1957.

Craven, Frank Wesley. The Legend of the Founding Fathers. Ithaca: Cornell University Press, 1965.

Crouthamel, James I. Bennett's New York Herald and the Rise of the Popular Press. Syracuse New York: Syracuse University Press, 1989.

David Levin. Forms of Uncertainty: Essays in Historical Criticism (Charlottesville: University Press of Virginia. 1992

David Levin. In Defense of Historical Literature: Essays on American History. Autobiography. Drama. and Fiction. New York: Hill and Wang, 1967.

Davis, David Brion. "Some Themes of Counter-Subversion: An Analysis of Anti-Masonic, Anti-Catholic, and AntiMormon Literature," The Mississippi Valley Historical Review 47 (September 1960):205-224.

Dawson, Jan C. "The Puritan and the Cavalier: The South's Perception of Contrasting Traditions," Journal of Southern History 44 (November 1978): 597-614.

Demos, John. Entertaining Satan : Witchcraft and the Culture of Early New England. New York: Oxford University Press, 1982.

Elson, Ruth Miller. Guardians of Tradition: American Schoolbooks of the Nineteenth Century. Lincoln: University of Nebraska Press, 1964.

John Mack Farragher. Daniel Boone: His Life and Legend. New York: OwI Books, 1992.

Faust, Drew Gilpin. The Creation of Confederate Nationalism: Ideology and Identity in the Civil War 
South. Baton Rouge, La.: Louisiana State University Press, 1988.

Finkleman, Paul (ed.). His Soul goes Marching on: Responses to John Brown and the Harpers Ferry Raid.

Charlottesville: University of Virginia Press, 1995.

Fitzgerald, Frances. America Revised: History Schoolbooks in the Twentieth Century. New York: Vintage Books, 1980 .

Fox, Richard Wightman. Trials of Intimacy: Love and Loss in the Beecher-Tilton Scandal. Chicago: University of Chicago Press, 1999.

Freehling, William. The Road to Disunion, 1776-1854. New York: Oxford University Press, 1990.

Frisch, Michael. "American History and the Structures of Collective Memory: A Modest Exercise in Empirical Iconography." The Journal of American History 75. no. 4 (March 1989): 1130-1155.

Givens, Terryl I. The Viper on the Hearth: Mormons, Myths and the Construction of Heresy. New York: Oxford University Press, 1997.

Goldberg, Alfred. "School Histories of the Middle Period," in Eric F. Goldman (ed.), Historiography and Urbanization: Essays in American History in Honor of W. Stull Holt. Port Washington, N.Y.: Kennikat Press, 1968.

Gomes, Peter. "Pilgrims and Puritans: 'Heroes' and 'Villains' in the Creation of the American Past." Proceedings of the Massachusetts Historical Society 95 (1983): 1-22.

Gould, Philip. "New England Witch-Hunting and the Politics of Reason in the Early Republic." New England Quarterly 68 (1995): 58-82.

Halbwachs, Maurice. On Collective Memory. Chicago: University of Chicago Press, 1992.

Hall, David D. "Readers and Writers in Early New England." in Hugh Amory and David D. Hall. The Colonial Book in the Atlantic World. vol. I New York: The American Antiquarian Society and Cambridge University Press, 2000. 
Hall, David D. "Witchcraft and the Iimits of Interpretation," New England Quarterly (Winter 1982): 253-81.

Halttunen, Karen. "Early American Murder Narratives: The Birth of Horror," in Richard Wightman Fox and T.J. Jackson Lears, eds. The Power of Culture: Critical Essays in American History. Chicago: University of Chicago Press, 1993.

Hartman, James D. Providence Tales and the Birth of American Literature. Baltimore: Johns Hopkins University, 1999.

Hatch, Nathan 0. The Democratization of American Christianity. New Haven: Yale University Press, 1989.

Helgerson, Richard. Forms of Nationhood: The Elizabethan Writing of England. Chicago: University of Chicago Press, 1992.

Hubbell, Jay. The South in American Literature, 1607-1900. Durham, N.C.: Duke University Press, 1954.

Hundley, Daniel Robinson. Social Relations in our Southern States. New York: H.B. Price, 1860.

Johnson, Paul E. A Shopkeeper's Millennium: Society and Revivals in Rochester, New York, 1815-1837. New York: Hill and Wang, 1978.

---- and Sean Wilentz. The Kingdom of Matthias: A Story of Sex and Salvation in 19th-Century America. New York: Oxford University Press, 1994.

Kaestle, Carl F. Pillars of the Republic, 1780-1860. New York: Hill and Wang, 1983.

Kamensky, Jane. Governing the Tongue: The Politics of Speech in Early New England. New York: Oxford University Press, 1997.

Kammen, Michael. In the Past Lane: Historical Perspectives on American Culture. New York: Oxford University Press, 1997.

Kammen, Michael. Mystic Chords of Memory: The Transformation of Tradition in American Culture. New York: Vintage, 1993.

Karal Ann Marling. George Washington Slept Here (Cambridge. Mass.: Harvard University Press, 1988. 
Karlsen, Carol F. The Devil in the Shape of a Woman:

Witchcraft in Colonial New England. New York: Norton, 1987.

Knight, Edgar W. Public Education in the South. Boston: Ginn and Company, 1922.

Lehuu, Isabelle. Carnival on the Page: Popular Print Media in Antebellum America. Chapel Hill: University of North Carolina Press, 2000.

Lepore, Jill. The Name of War: King Philip's War and the Origins of American Identity. New York: Vintage. 1999.

Levin, David. Forms of Uncertainty: Essays in Historical Criticism. Charlottesville: University Press of Virginia, 1992.

Levin, David. In Defense of Historical Literature: Essays on American History, Autobiography, Drama, and Fiction. New York: Hill and Wang, 1967.

Lowenthal, David Lowenthal. "Past Time, Present Place: Landscape and Memory," Geographical Review 65 (1975): $1-31$.

Lowenthal, David. The Past is a Foreign Country. New York: Cambridge University Press, 1985.

McCardell, John. The Idea of a Southern Nation: Southern Nationalism, 1830-1860. New York: W. W. Norton, 1979.

McCarl, Mary Rhinelander. "Spreading the News of Satan's Malignity in Salem: Benjamin Harris. Printer and Publisher of the Witchcraft Narratives." Essex Institute Historical Collections 129 (January 1993): 39-61.

McDade, Thomas M. "Matthias, Prophet without Honor," New York Historical Society Quarterly 62 (1977):311-34.

McPherson, James M. Ordeal by Fire: The Civil War and Reconstruction. New York: Alfred A. Knopf, 1982.

Mellow, James R. Nathaniel Hawthorne in His Times. Baltimore: Johns Hopkins University Press, 1980.

Miller, Perry. The New England Mind: From Colony to Province. Cambridge, Mass.: Harvard University Press, 1956.

Mintz, Steven. Moralists and Modernizers: America's PreCivil War Reformers. Baltimore: Johns Hopkins University Press, 1995. 
Moore, R. Laurence. In Search of White Crows: Spiritualism, Parapsychology, and American Culture. New York: Oxford University Press, 1977.

-----. Religious Outsiders and the Making of Americans. New York: Oxford University Press, 1986.

Nevins, Alan. Ordeal of the Union. 2 vols. New York: Charles Scribner's Sons, 1947.

Numbers, Ronald and Janet S. Numbers. "Millerism and Madness: A Study of 'Religious Insanity' in Nineteenth-Century America," in Ronald L. Numbers and Jonathan M. Butler. The Disappointed: Millerism and Millenarianism in the Nineteenth Century. Bloomington: Indiana University Press, 1987.

Perkins, Howard C. "A Neglected Phase of the Movement for Southern Unity, 1847-1852," Journal of Southern History 12 (May 1946): 153-203.

Pestana, Carla Gardina. "The Quaker Executions as Myth and History." Journal of American History 80, no.2 (September 1993): 441-69.

Peterson, Merrill. Lincoln in American Memory. New York: Oxford University Press, 1994.

-----. The Jefferson Image in the American Mind (New York: Oxford University Press, 970.

Potter, David M. The Impending Crisis, 1848-1861. Completed and edited by Don E. Fehrenbacher. New York: Harper, 1976.

Quinn, D. Michael. Early Mormonism and the Magic World View. Salt Lake City, Utah: Signature Books, 1987.

Randall, J.G. "The Blundering Generation," Mississippi Valley Historical Review 27 (June 1940): 4-16.

Reis, Elizabeth S. Damned Women: Sinners and Witches in Puritan New England. Ithaca: Cornell University Press, 1997.

Rosenthal, Bernard. Salem Story: Reading the Witch Trials of 1692. New York: Cambridge University Press, 1993.

Rothman, David J. The Discovery of the Asylum: Social Order and disorder in the New Republic. Boston: Little and Brown, 1971. 
Rowe, David I. Thunder and Trumpets: Millerites and dissenting Religion in Upstate New York, 1800-1850. Chico, Calif.: Scholars Press, 1985.

Saxton, Alexander. The Rise and Fall of the white Republic: Class Politics and Mass Culture in Nineteenth-Century America. New York: Verso, 1988.

Schiller, Dan. Objectivity and the News: The Public and the Rise of Commercial Journalism. Philadelphia: University of Pennsylvania Press, 1988.

Seelye, John. Memory's Nation: The Place of Plymouth Rock. Chapei. Hill: University of North Carolina Press, 1998.

Sheidley, Harlow W. Sectional Nationalism: Massachusetts Conservative Leaders and the Transformation of America, 1815-1836. Boston: Northeastern University Press, 1998.

Shipps, Jan. Mormonism: The Story of a New Religious Tradition. Urbana: University of Illinois Press, 1985.

Slotkin, Richard. Regeneration through Violence: The Mythology of the American Frontier, 1600-1860. New York: Harperperennial, 1996.

Stevens, John D. Sensationalism and the New York Press. New York: Columbia University Press, 1991.

Stronks, G.J. "The Significance of Balthasar Bekker's The Enchanted World. in Marijke Gijswijt Hofstra and Willem Erijhoff. eds. Witchcraft in the Netherlands from the Eourteenth to the Twentieth Century. trans. Rachel J.J. van der Wilden Fall. Rotterdam: Universitaire Pers, 1991.

Taylor, William R. Cavalier and Yankee: The Old South and American National Character. Garden City, N.Y.: George Braziller, 1963.

Thelen, David. "Memory and American History," The Journal of American History 75, no. 4 (1989): 1117-29.

Tilton, Robert S. Pocahontas: The Evolution of an American Narrative. New York: Cambridge University Press, 1994.

Tompkins, Jane. Sensational Designs: The Cultural World of American Fiction. New York: Oxford University Press, 1985.

Tryon, Rolla M. The Social Sciences as School Subjects. New York: Ginn. 1935. 
Tyanck, David B. "Forming the National Character: Paradox in the Educational Thought of the Revolutionary Generation," Harvard Educational Review 36 (Winter 1966).

Van Tassel, David. Recording America's Past: An Interpretation of the Development of Historical Studies in America, 1607-1884. Chicago: University of Chicago Press, 1960.

Van Wyck, Charles. "The Despotism of Slavery." $36^{\text {th }}$ cong., $1^{\text {st }}$ sess. June $16,1860$.

Vartanian, Pershing. "The Puritan as a Symbol in American Thought: A Study of the New England Societies, 18201920." Ph.D. diss., University of Michigan, 1971.

Waldstreicher, David. In the Midst of Perpetual Fetes: The Making of American Nationalism. Chapel Hill:

University of North Carolina for the Omohundro Institute of Eariy American History and CuIture. 1997.

Walters, Ronald G. American Reformers, 1815-1860. New York: Hill and Wang, 1978.

-----. The Anti-Slavery Appeal: American Abolitionism after 1830 (Baltimore: Johns Hopkins University Press, 1976.

Warner, Michael. Letters of the Republic: Publication and the Public Sphere in Eighteenth-Century America. Cambridge. Mass: Harvard University Press, 1992.

Winn, Kenneth H. Exiles in a Land of Liberty: Mormons in America. Chapel Hill: University of North Carolina Press, 1989.

Wiswall, J.T. Delusions of Fanaticism."DeBow's Review (July 1860): 42-61.

Yazawa, Melvin C. "Creating a Republican Citizenry." in Jack P. Greene. ed. The American Revolution: Its Character and Limits. New York: New York University Press. 1987.

Zelinsky, Wilbur. Nation Into State : The Shifting Symbolic Foundations of American Nationalism. Chapel Hill: University of North Carolina Press, 1988. 